\title{
Site U1378
}

\author{
Expedition 334 Scientists $^{2}$
}

\section{Chapter contents}

Background and scientific objectives ...... 1

Operations................... 2

Lithostratigraphy and petrology ....... 3

Paleontology and biostratigraphy ......5

Structural geology...............6

Geochemistry and microbiology. . . . . . . 7

Physical properties . . . . . . . . . 8

Paleomagnetism . . . . . . . . . . . . 10

Downhole logging . . . . . . . . . . 12

References................... 15

Figures..................... 17

Tables...................... 55

1Expedition 334 Scientists, 2012. Site U1378. In Vannucchi, P., Ujiie, K., Stroncik, N., Malinverno, A., and the Expedition 334 Scientists, Proc. IODP, 334: Tokyo (Integrated Ocean Drilling Program Management International, Inc.). doi:10.2204/iodp.proc.334.103.2012 'Expedition 334 Scientists' addresses.

\section{Background and scientific objectives}

Integrated Ocean Drilling Program Site U1378 (proposed Site CRIS-3B) was drilled into the middle slope of the Costa Rica margin, $38 \mathrm{~km}$ offshore Osa Peninsula and $24 \mathrm{~km}$ from Caño Island along seismic BGR99 Line 7 (Fig. F1). This site was chosen because it is located above the unlocked portion of the plate boundary, as indicated by interplate earthquake relocation and geodetic measurements (S.L. Bilek, pers. comm., 2003; I.G. Arroyo, pers. comm., 2008; LaFemina et al., 2009). Within the Costa Rica Seismogenesis Project, this location is considered as complementary to the upper slope site located above the seismic portion of the plate boundary.

The primary purpose of drilling Site U1378 was to determine the nature, composition, and physical properties of the upper plate basement, which is considered to be the main source of material in a erosive plate boundary system. Moreover, seismic sections show that this site is above the seaward edge of one of the highamplitude, landward-dipping reflectors interpreted as normal faults. These landward-dipping reflectors appear as a characteristic feature of the Costa Rica forearc along the Expedition 334 transect. Operations at Site U1378 were designed to penetrate one of these reflectors to understand their nature.

In order to quantify the material input into the seismogenic zone of the plate interface, it is important to constrain volume and timing of subduction erosion/accretion. Our strategy was to drill the slope sequence at least in two locations and compare results to reconstruct the stratigraphy of the sediments and document the margin subsidence/uplift. Specifically Site U1378 was located in an area of the middle slope with a relatively thick sequence of slope sediment in order to better decipher, for example, the occurrence of discontinuities. The margin here consists of $\sim 750 \mathrm{~m}$ thick slope sediments overlying upper plate basement as defined in the seismic lines by prominent reflectors and increasing $P$-wave velocity (Figs. F1, F2).

Additional objectives included

- Determining the stress and strain regime of the unlocked portion of the margin,

- Understanding the fluid-flow regime above the high-amplitude reflector interpreted as a fault, and 
- Calibrating the bottom-simulating reflectorderived temperature.

The seismic interpretation of Site U1378 is based on the prestack depth-migrated seismic BGR99 Line 7 processed by C.R. Ranero (Fig. F1). The site is located at common midpoint $2500\left(8^{\circ} 35.5414^{\prime} \mathrm{N}, 84^{\circ} 4.6306^{\prime} \mathrm{W}\right)$ at 527 meters below sea level (mbsl). The seismic stratigraphy of the sedimentary slope at Site U1378 shows a good continuity of reflection events (Fig. F2). The uppermost $100 \mathrm{~m}$ of the slope sediment sequence shows clear horizontal reflections. The underlying $100 \mathrm{~m}$ of sediment forms the weakest reflective part of the sequence. From there the sequence grades downward in a more highly reflective zone that is basically continuous between 500 and 600 meters below seafloor (mbsf). The reflectors in this interval gently dip seaward, and the sequence is clearly cut upslope (toward the northeast) by a younger sequence, forming an angular unconformity. The lowermost part of the sedimentary sequence is sharply marked by a high-amplitude reflector interpreted as the top of the upper plate basement. The velocity increases from $<2 \mathrm{~m} / \mathrm{s}$ in the sediment to $2.8 \mathrm{~m} / \mathrm{s}$ in the fault zone to $>3.3 \mathrm{~m} / \mathrm{s}$ in the basement. The surface marking the basement top is irregular and cut by several landward high-amplitude reflectors interpreted as faults. The basement top is displaced a few tens of meters across these faults. Around Site U1378, the slope sediments are thickened, but not visibly deformed by the faults. Thickening occurs in correspondence to the fault cutting the basement reflector, suggesting normal displacement. Some growing strata visible along BGR99 Line 7 also confirm this normal sense of displacement.

At Site U1378, the temperature at the plate boundary was interpreted to be at least $140^{\circ} \mathrm{C}$ (Grevemeyer et al., 2004). Recent modeling of the intraplate temperature interprets it to be between $60^{\circ} \mathrm{C}$ and $90^{\circ} \mathrm{C}$ (Harris et al., 2010). Visual observations and the towed ocean bottom instrument detected abundant mud mounds and vent communities within a few kilometers of the site (McAdoo et al., 1996; Weinrebe and Ranero, 2003). Many of these structures collect fluids from areas with thermogenic hydrocarbon sources (Hensen et al., 2004) and they seem to be related to the landward-dipping reflectors interpreted as active faults (Ranero et al., 2008). Judging from the continuity of the landward-dipping reflectors and the presence of thermogenic hydrocarbon in fluids, any fluid advection along these structures originates in areas of at least $4 \mathrm{~km}$ depth.

\section{Operations}

Two holes were drilled or cored at this site (Table T1). The first hole was drilled with an $81 / 2$ inch drill bit with logging-while-drilling (LWD) tools in the BHA to 456.9 mbsf. The next hole was cored with the advanced piston corer (APC)/extended core barrel (XCB) coring system to 523.9 mbsf. The advanced piston corer temperature tool (APCT-3) was deployed four times, and usable data were recovered four times. The Flexit tool was deployed on all 16 piston cores in Hole U1378B. All APC holes were cored with nonmagnetic core barrels. Recovery for Site U1378 was $101.4 \%$ with the APC system and $100.3 \%$ with the XCB system. Overall core recovery for Site U1378 was $100.5 \%$. A total of 63 cores were recovered after coring $523.9 \mathrm{~m}$. The total length of core recovered at this site was $526.69 \mathrm{~m}$. Hole U1378B was terminated after Core 334-U1378B-63X when hole conditions deteriorated and could not be remediated.

\section{First transit to Site U1378}

After an $8.6 \mathrm{~h}$ transit from Puntarenas, Costa Rica, covering $94 \mathrm{nmi}$ and averaging $10.8 \mathrm{kt}$, speed was reduced and thrusters and hydrophones were lowered. Dynamic positioning was initiated over Site U1378 at $1000 \mathrm{~h}$ (Universal Time Coordinated [UTC] $-6 \mathrm{~h}$ ) on 17 March 2011. The position reference was a combination of GPS signals and a single acoustic beacon. The positioning beacon was deployed at $1109 \mathrm{~h}$ on 17 March. The beacon was left on site for our return after Site U1379.

\section{Hole U1378A}

Rig floor operations commenced at $1000 \mathrm{~h}$ on 17 March. The trip to the seafloor was uneventful. The top drive was picked up, the drill string was spaced out, and the LWD hole was spudded at $0425 \mathrm{~h}$ on 18 March. After 37.5 h of drilling, Hole U1378A was terminated at 456.9 mbsf. High standpipe pressures, lost circulation, and high torque contributed to the decision to abandon the hole. A wiper trip was attempted, but given the time available versus the progress made to date, the decision was made to terminate Hole U1378A and move to Site U1379 and complete LWD drilling at the second site. After picking up off bottom, the hole was displaced with heavy drilling mud (10.5 ppg) and the drill string was tripped out of the hole to $\sim 640$ meters below rig floor (mbrf) while experiencing high torque and significant overpull. The top drive was set back and the drill string was tripped the rest of the way to surface. 
The $6 \frac{1}{2}$ inch drill collars were set back in the derrick. The LWD tools were stored for transit and the rig floor was secured. Thrusters and hydrophones were pulled and the vessel was put into cruise mode, ending Hole U1378A at $0230 \mathrm{~h}$ on 20 March.

\section{Second transit to Site U1378}

After a $1.25 \mathrm{~h}$ transit from Site U1379 covering $6 \mathrm{nmi}$ and averaging $4.8 \mathrm{kt}$, speed was reduced and thrusters and hydrophones were lowered. Dynamic positioning was initiated over Site U1378 at 1100 h (UTC $-6 \mathrm{~h}$ ) on 2 April. The position reference was a combination of GPS signals and a single acoustic beacon. On reoccupation of Site U1378, the beacon which had been left on bottom was nonresponsive and declared lost. Another beacon was deployed at 1204 hours on 2 April and was recovered at 2042 h on 6 April.

\section{Hole U1378B}

After offsetting the vessel $20 \mathrm{~m}$ west, Hole U1378B was spudded at $1515 \mathrm{~h}$ on 2 April and advanced with the APC coring system to 127.8 mbsf before refusal. All cores after the fifth core were partial strokes, and the hole was advanced by recovery. The coring system was switched to the $\mathrm{XCB}$, and coring continued from Core 334-U1378B-17X through 63X. Temperature measurements were taken with the APCT- 3 on Cores $4 \mathrm{H}, 7 \mathrm{H}, 10 \mathrm{H}$, and $13 \mathrm{H}$. Microspheres were run on Cores 20X, 30X, 40X, 50X, and 60X. A total of 16 APC cores were taken with a total recovery of 129.56 $\mathrm{m}$ for an overall APC recovery in Hole U1378B of $101.4 \%$. A total of $47 \mathrm{XCB}$ cores were taken over a $396.1 \mathrm{~m}$ interval, recovering $396.83 \mathrm{~m}$ of core for a XCB recovery of $100.3 \%$.

Coring was terminated after Core 334-U1378B-63X when it became impossible to continue advancing. High top drive torque and lost circulation were major factors. A wiper trip was run to try to clean up the hole, but it was impossible to return to bottom. The hole was terminated, plugged, and then abandoned.

The total cored interval in Hole U1378B was $523.9 \mathrm{~m}$ with $526.69 \mathrm{~m}$ of core recovered for an $\mathrm{APC} / \mathrm{XCB}$ combined recovery of $100.5 \%$. The last core on deck for Hole U1378B was at $0035 \mathrm{~h}$ on April 6. After trying to condition the hole for $14.5 \mathrm{~h}$, the decision to abandon the hole was made. The hole was displaced with $10.5 \mathrm{ppg}$ mud, and the drill string was pulled back to 960 mbrf with the top drive in place. The top drive was set back and the remainder of the drill pipe and BHA were tripped back to the surface. The seafloor was cleared at $1850 \mathrm{~h}$ and the bit cleared the rotary table at $2030 \mathrm{~h}$. The rig was secured for transit and the beacon was recovered at $2042 \mathrm{~h}$, ending Hole U1378B at $2045 \mathrm{~h}$ on 6 April.

\section{Lithostratigraphy and petrology}

The objective at Site U1378 was to investigate the nature and deformation of the midslope sedimentary sequence and the uppermost portions of the basement imaged in multichannel seismic reflection data (Fig. F3). After taking LWD measurements in Hole U1378A, Hole U1378B was cored from the seafloor to $523.9 \mathrm{mbsf}$, recovering sediment and sedimentary rocks. Because of deteriorating hole conditions, the hole was terminated before reaching the basement.

Hole U1378B is dominantly composed of a monotonous sequence of silty clay to clay that alternates with widely interspersed centimeter-scale sandy layers. The interval between Core 334-U1378B-1H and $16 \mathrm{H}(\sim 0-128 \mathrm{mbsf})$ is dominated by soft silty clay sediments. Twenty-one tephra layers and numerous thin $(<5 \mathrm{~cm})$ fining-upward sand sequences with erosive bases were observed in this sequence.

In the interval between Core 334-U1378B-17X and 62X ( 128-513.6 mbsf), a monotonous compacted sequence of silty clay to clay alternates with widely interspersed decimeter-scale sandy layers. Sandy layers are most common in the $146 \mathrm{~m}$ interval between 367 mbsf (Core 45X) and 513 mbsf (Core 62X). Sandy sequences become thicker and more abundant with increasing depth within this interval. Shell fragments are widely dispersed throughout the monotonous clay sequence. Below 128 mbsf, a sequence of 61 tephra horizons is observed. The sands change character in Core 45X ( 367 mbsf), gradually becoming progressively coarser and more terrigenous with depth. The lowermost core recovered from Hole U1378B (Core 63X) contains a $0.97 \mathrm{~m}$ thick sequence of extensively fractured silty claystones.

\section{Description of units}

The cores recovered at Site U1378 can be divided into two lithostratigraphic units (Fig. F4; Table T2). The $523.9 \mathrm{~m}$ sequence (Cores 334-U1378B-1H through 63X) is divided on the basis of lithologic attributes. Core recovery was extraordinary $(>100 \%)$. Lithostratigraphic definitions for Site U1378 are based exclusively on core recovered from Hole U1378B.

\section{Unit I}

Interval: 334-U1378B-1H through $16 \mathrm{H}$

Thickness: $127.83 \mathrm{~m}$ 
Depth: 0-127.83 mbsf

Age: late Pleistocene? to recent

Lithology: fine soft silty clay sediment with finingupward sandy sequences

Unit I consists mainly of dark greenish gray, soft silty clay sediments (Fig. F5). These clays are punctuated by a series of fining-upward $<5 \mathrm{~cm}$ thick sequences of lithic sand and 21 tephra layers. The sandy packages have abrupt parallel bases with rounded medium-grained sand that transition to a gradational boundary at the top of the package (Fig. F5). Tephra layers range from 0.5 to $7 \mathrm{~cm}$ thick and commonly have abrupt bases and gradational tops.

The main components of Unit I are terrigenous, dominantly clay. Smear slides indicate that the most common accessory grains in the silt(stone) and clay(stone) in Cores 334-U1378B-1H to 5H include feldspar and lithic (sedimentary and magmatic) fragments. Components present in trace abundances include chert, opaque minerals, and volcanic glass fragments, as well as foraminifers, diatoms, and nannofossils. From Core $5 \mathrm{H}$ downhole, trace components in the background sediment also include chlorite, calcite, amphibole, and pyroxene. Similarly, the main components in the sandstones of Unit I change composition as a function of depth. Whereas the variability of clast and mineral phases within the small intercalated sandstone beds of the upper part is high (sedimentary and magmatic lithic fragments > feldspar, pyroxene, shell fragments, and foraminifers $>$ amphibole and calcite $>$ nannofossils and chlorite $>$ volcanic glass, quartz, and biotite), the sandstones in the lower cores (334-U1378B-10H to $16 \mathrm{H}$ ) are mainly dominated by shell fragments, foraminifers, lithic fragments (sedimentary lithic fragments >> magmatic lithic fragments), and feldspar. Additionally, amphibole pyroxene and opaque minerals and rare glass shards are present within the sandy horizons. Biogenic components also include sparse nannofossils and diatoms.

\section{Unit II}

Intervals: 334-U1378B-17X through 62X

Thickness: $385.73 \mathrm{~m}$

Depth: 127.83-513.56 mbsf

Age: late? Pliocene to late Pleistocene

Lithology: clay(stone), silt(stone), and sand(stone)

Unit II is dominantly olive-green clayey silt(stone) and silty clay(stone) with minor layers of sand(stone), sandy silty clay(stone), clay, clayey silt(stone), and tephra (Fig. F6). The sediment is firm and well consolidated and contains tephra layers that remain unlithified to 506 mbsf (Section 334U1378B-61X-1). In general, Unit II is massive with minor changes in the proportions of clay, silt, and sand grain sizes occurring gradually over $<3 \mathrm{~m}$ intervals.

Within this monotonous sequence, sandy intervals become thicker and more common with depth. An upper $146.96 \mathrm{~m}$ thick interval of clay-rich finer sediment extends from Core 334-U1378B-17X through $44 \mathrm{X}$. This sequence has a minor proportion of sand (a cumulative thickness of $26.28 \mathrm{~m}$, or $11 \%$ ). Small burrows are the dominant sedimentary structure preserved in this interval. In contrast, the lower section (146.96 $\mathrm{m}$; Core $45 \mathrm{X}$ through $62 \mathrm{X}$ ) contains two sandy intervals between Cores $45 \mathrm{X}$ to $49 \mathrm{X}$ (367-400 mbsf) and 55X to 60X (447-503 mbsf), which are superimposed on the background silty clay sedimentation. The lowermost portions of the core (depths > 367 mbsf) are composed of 59\% sand-sized sediment. Coarse to very coarse loose sand layers are limited to two narrow $(<8 \mathrm{~m})$ intervals between 391-399 mbsf (Core 49X) and 468-474 mbsf (Sections 334U1378B-57X-2 to 57X-7).

Throughout Unit II, fining- and coarsening-upward decimeter-scale sequences of sand are present. In the coarser sand layers, rip-up clasts, rounded clay lenses, and abundant shell fragments are commonly observed. Framboidal pyrite was observed both macroscopically and in many of the smear slides throughout Unit II. Shell fragments, diatoms, and nannofossils are sparse but ubiquitous throughout Unit II. Foraminifers are partly enriched within the sediments and are a major constituent of the sandsized fraction (especially the sandy silt[stones]). Wood or plant material is rarely found in Unit II, although in Core 334-U1378B-24X (193.95-199.9 mbsf) wood fragments (charcoal) and organic matter are common. Intervals of abundant calcareous concretions or lithified carbonate mud clasts are rare and concentrated within a $2 \mathrm{~m}$ interval of Core $27 \mathrm{X}$ (Sections 334-U1378B-27X-4 to 27X-CC; 222.08$224.41 \mathrm{mbsf})$.

The main components of Unit II are terrigenous, dominantly clay. Smear slides indicate that the most common accessory grains in the silt(stone) and clay(stone) include feldspar and lithic (sedimentary and magmatic) fragments. Components present in trace abundances include amphibole, calcite, biotite, chlorite, glass shards, and opaque minerals. The main components in the sandstones are lithic (sediment > magmatic) clasts and feldspar crystals. Biogenic components are rare but include nannofossils, diatoms, and foraminifers.

\section{Tephra layers}

Hole U1378B cores contain 82 tephra layers intercalated with the background sediment of Units I and II. Individual tephra layers range in thickness from 
0.5 to $48 \mathrm{~cm}$. In Unit I, the interval between Cores 334-U1378B-1H and 16H (0-128 mbsf), 21 tephra layers are widely distributed within the background silty clay sediment. In Unit II, 49 tephra horizons are identified in the upper silty clay-rich sediment succession, concentrated in two intervals from $134 \mathrm{mbsf}$ (Section 334-U1378B-18X-2) to 166 mbsf (Section 21X-4) and 205 mbsf (Section 25X-5) to $333 \mathrm{mbsf}$ (Section 40X-7), containing 9 and 38 tephra layers, respectively. Between 354 mbsf (Core 43X) and the bottom of the hole (523.9 mbsf), 14 additional tephra layers are recognized. In general, tephra is most common in the upper part of Unit II.

Compositions of the 82 identified tephra layers are variable. Of all the layers, 30 are light gray to pinkish/brownish white felsic ash, 40 are pinkish gray/ brown layers, and 12 are pinkish/greenish black layers. Dark black tephra layers account for $\sim 15 \%$ of the total tephra/bed assemblage in Hole U1378B. Tephra layers are usually soft, but those from Core $52 \mathrm{X}$ downward are indurated and fulfill the definition of tuff.

Unconformable and/or inclined bedding of tephra horizons is rare. In some instances, the tops of the tephra layers exhibit bioturbation. In general, the tephra layers are characterized by a sharp basal contact with the subjacent terrigenous sediment and a gradational contact with the overlying ash-bearing pelagic sediment. Many layers are normally graded and well-sorted (Fig. F7). Felsic white ash is mainly (>90 vol\%) composed of clear, colorless glass shards varying from angular blocky, cuspate, flat, and Yshaped shards with nearly no bubbles to highly vesicular, pumiceous textures with many elongated bubbles.

The transparent glass shards of the felsic tephras show no visible signs of alteration until $439 \mathrm{mbsf}$ (Core 334-U1378B-60X). Grain size ranges from very fine to coarse ash (millimeter size). The mineral assemblages in the tephra consist of plagioclase, pyroxene, amphibole, and biotite but vary in abundance and composition. These variations are likely diagnostic for variations in the source areas. Smear slides indicate a decrease in mineral contents and species in the more evolved tephras from Cores $7 \mathrm{H}$ to $15 \mathrm{H}$ within Unit I, whereas felsic tephras below Core 20X are dominated by a high amount of crystals (e.g., amphibole, feldspar, and biotite). Plagioclase is the dominant phenocryst phase, but some tephras are dominated by amphibole and biotite, which typically occur in the most evolved felsic layers. Dark gray mafic ash layers consist dominantly of dark to light brown glass shards. Most of the glass shards have blocky shapes, are medium to poorly vesicular, and show evidence of extensive alteration, especially in the deeper portions of the hole. The mineral assemblages of the mafic tephras include plagioclase, pyroxene, and spinel. Relative to felsic tephras, the mafic tephras contain more crystals.

\section{$\mathrm{X}$-ray diffraction analysis}

Preliminary X-ray diffraction analyses of the sediment suggest that lithostratigraphic Units I and II are compositionally similar. X-ray diffractograms indicate that the major mineral components are clay minerals including illite, smectite, kaolinite, attapulgite, and chlorite, as well as primary minerals including calcite, anorthite, and quartz. Amphibole (hornblende and richterite), chlorite, pyroxene (augite), and pyrite peaks are also recognized (Fig. F8).

\section{Depositional environment}

The cover sequence recovered from Hole U1378B is a terrestrially sourced upper slope sequence consistent with high sediment accumulation rates throughout the depositional interval (Fig. F3) (see also "Paleontology and biostratigraphy"). Recognition of wood debris and thin $(<5 \mathrm{~cm})$ normal-graded sands with sharp erosional bases within Unit I in Hole U1378B is consistent with deposition within the distal facies of a clastic turbidite sequence.

\section{Paleontology and biostratigraphy}

Shipboard studies of calcareous microfossils (calcareous nannofossils and foraminifers) allow constraints on age and depth of the middle slope sediments of the Costa Rica subduction zone. Pleistocene calcareous nannofossils as well as foraminifers were observed in the marine sediment samples retrieved at Site U1378. The calcareous nannofossil record provides strong biostratigraphic control for this section (Fig. F9). The sediments throughout the core are estimated to be at least lower-middle Pleistocene in age. Approximate sediment accumulation rates are based on the last occurrence datums of the observed microfossils (Fig. F10).

\section{Calcareous nannofossils}

A particularly thick Pleistocene section is observed in the calcareous nannofossil record recovered from Site U1378B. Presence, relative abundance, and preservation are documented in Table T3. Sample abundances range from barren to abundant and in general show moderate to good preservation. For the most part, the assemblage abundances and the presence of key marker species were sufficient to delineate biozonal boundaries. 
Samples 334-U1378B-1H-CC (5.36 mbsf) through 27X-CC (224.39 mbsf) are assigned to the undifferentiated Zones NN21-NN20 of the upper to middle Pleistocene based on the presence of Emiliania huxleyi in Sample 1H-CC (5.36 mbsf) and the absence of Pseudoemiliania lacunosa. Good preservation allows the tentative identification of E. huxleyi in Samples 1H-CC (5.36 mbsf) through 16H-CC (127.91 mbsf). However, because of the small size of this species, positive identification must be made on the basis of scanning electron microscopy.

Samples 334-U1378B-28X-CC (237.47 mbsf) through $63 \mathrm{X}-\mathrm{CC}$ are assigned to Zone NN20 based on the last occurrence of $P$. lacunosa in Sample 28X-CC (237.47 mbsf) and the absence of Discoaster brouweri. Sample 57X-CC (476.18 mbsf) contains the first occurrence of early Pleistocene marker Helicosphaera sellii. Dominant species include Helicosphaera carterii, Gephryocapsa oceanica, Gephryocapsa caribbeanica, Gephryocapsa small, and Calcidiscus leptoporus.

\section{Foraminifers}

Sample 334-U1378C-5H-CC (43.77 mbsf) contains the pink-colored Globigerinoides ruber (last appearance age of $0.12 \mathrm{Ma}$, located in marine isotope Stage 5e). In contrast, Sample 334-U1378C-4H-CC (34.62 mbsf) does not contain the pink specimen. Thus, the onset of marine isotope Stage 5e would be located in the interval between these two samples.

Coiling change of planktonic foraminiferal genus Pulleniatina from sinistral to dextral was observed from Sample 334-U1378C-42X-CC (351.71 mbsf) to 30X-CC (245.19 mbsf), but the precise horizon of the coiling change was not identified. Thus, at least the lower Sample 42X-CC would be older than 0.8 Ma in age.

\section{Structural geology}

The primary structural geology objective during Expedition 334 was to describe and document style, geometry, and kinematics of structural features observed in the cores. At Site U1378, bedding dips are shallow $\left(<20^{\circ}\right.$, mostly $<15^{\circ}$; Fig. F11). A faint northeast-southwest-trending alignment of poles to bedding planes is identified after paleomagnetic correction. Structures are dominated by normal faults. In addition, there are a large number of healed faults. There are four fault zones at 280 mbsf, 375-380 mbsf, 477 mbsf, and 498-520 mbsf. Healed faults and sediment veins occur at $\sim 260$ mbsf, $\sim 20 \mathrm{~m}$ above the shallowest appearance of the fault zone. Paleomagnetic corrections were conducted for three normal faults. All are within $35^{\circ}$ of an east-west strike and dip $\sim 70^{\circ}$ to the north or south.

\section{Structures in slope sediments}

\section{Bedding}

Bedding planes dip gently, commonly $<15^{\circ}$ throughout the borehole (Fig. F11). Below 300 mbsf, the number of steeper dipping bedding planes $\left(15^{\circ}-30^{\circ}\right)$ increases slightly. Although bedding planes show shallow inclination, paleomagnetic correction identified a faint northeast-southwest-trending alignment of poles to the bedding plane (Fig. F12).

\section{Brittle faults}

Faults recognized in the Hole U1378B cores are characterized by striated and/or polished surfaces or by offset markers. The sense of slip is determined by offset markers such as lamination, bioturbation, and slickensteps on striated slip surfaces. The faults commonly show a normal sense of displacement, although some faults $(n=7)$ show a reverse sense of shear. In the interval between 204 mbsf and 510 mbsf, 33 normal faults were recognized (Fig. F11), with a mean dip $>60^{\circ}$.

Only three of the 33 measured normal fault attitudes can be restored to the geographic frame because of the difficulties in paleomagnetic measurement due to the extensive biscuiting and magnetic overprinting. These three faults have similar orientations, striking within $35^{\circ}$ of east-west and dipping $\sim 70^{\circ}$ to the north or south (Fig. F13).

\section{Fractures and mineral veins}

A total of 33 fractures and joints, closely associated with fault zones, were measured in Hole U1378B. The fractures are preferentially subhorizontal or steeply to subvertically dipping. Only one of the fractures could be restored using paleomagnetic data, resulting in an orientation of $82^{\circ}$ dipping toward $56^{\circ}$ (right-hand rule).

Mineral veins and en echelon veins were also identified. Most of the veins are filled with calcite and are steeply dipping $\sim 70^{\circ}$. They are frequently located adjacent to faults and fractures.

\section{Healed faults and sediment-filled veins}

A total of 49 healed faults were concentrated in the interval between 249 and 502 mbsf within lithostratigraphic Unit II. The fillings are all less than a few millimeters thick and indicate fault cohesiveness. The cohesiveness of the fault plane may represent early stage, soft-sediment deformation. These healed faults have preferentially steep dip angles $\left(45^{\circ}-80^{\circ}\right)$.

Sediment-filled veins aligned in arrays parallel or subparallel to the bedding planes were identified at 
262-387 mbsf (Figs. F14, F15). Sediment-filled vein structures include a variety of structures, many of which have been identified during previous ocean drilling expeditions. This category of structures includes the sigmoidal-shaped suite of thin, mud-filled veins that are slightly darker than the surrounding materials and was first documented by Ogawa (1980) and Cowan (1982). Dark veins are spaced at regular intervals $(0.5-2.0 \mathrm{~mm})$ in the horizontal plane (Fig. F15). Each vein is preferentially oriented vertically to subvertically to the vein arrays. Apparent offsets across the vein arrays in the split cores indicate mostly normal displacements.

\section{Fractured and brecciated zones}

Fractured zones are defined as moderately sheared zones fractured into centimeter-size fragments. Brecciated zones represent intensively sheared zones composed mainly of angular millimeter to $1 \mathrm{~cm}$ sized fragments (Fig. F16). Each fragment has an angular shape with slickenlines showing a straight and parallel striation on all of its surfaces in a systematic direction. For the most part, these features are distinguishable from drilling-induced fractures and clasts (see "Structural geology" in the "Methods" chapter [Expedition 334 Scientists, 2012]).

All major fault zones shown in Figure F11 are characterized by alternating sequences of fractured and brecciated zones. The top and bottom boundaries of these zones are characterized by a weakly fractured zone and/or undisturbed host rock. Four fault zones were identified at 280, 375-380, 477, and 498-520 mbsf (Fig. F11). All fault zones are located within lithostratigraphic Unit II of Site U1378.

The shallowest fault zone occurs between 279.3 and $281.4 \mathrm{mbsf}$ and consists of a $>0.8 \mathrm{~m}$ thick brecciated zone in the center and accompanying fracture zones above and below.

The second shallowest fault zone ranges from 375.4 to 383.7 mbsf. This fault zone consists of two main brecciated zones, one $\sim 2.0 \mathrm{~m}$ wide and the other 1.8 $\mathrm{m}$ wide. Because of the thickest brecciated intervals and the relatively smaller size of fragments than that in the other fault zones, the second fault zone appears to have experienced the most intense deformation. This depth interval corresponds to a low-density, high-porosity interval identified by LWD (see "Downhole logging").

\section{Geochemistry and microbiology Geochemistry}

We collected 84 whole-round samples in Hole U1378B for pore fluid analysis. The sample fre- quency was two samples per core in the uppermost 87 mbsf followed by one sample per core in the remainder of the hole. The uppermost interval (Core 334-U1378B-1H to Section 8H-2; 0-64 mbsf) was processed under a nitrogen atmosphere to preserve the reduced dissolved species and their isotopic composition (Fe and Mo), which will be analyzed postcruise. The remaining samples were exposed to the atmosphere prior to squeezing. Because of time constraints, we focused our efforts on collecting samples for postcruise studies and only a limited number of analyses were carried out onboard. For the organic geochemistry program, 65 headspace (HS) samples were collected for safety monitoring. In addition, 99 void gas samples (VAC) were collected, when present, and 173 gas samples (NZ) preserved with 10\% $\mathrm{KCl}$ solution were sampled for shipboard analysis. The data reported are from $69 \mathrm{NZ}$ samples analyzed at this site. The inorganic and organic geochemistry data are listed in Tables T4, T5, and T6 are plotted in Figures F17, F18, F19, and F20. Microbiology data (cell counts) are shown in Figures F21 and F22.

The pore fluid profiles of sulfate, alkalinity, ammonium, methane, and calcium in the uppermost 20 mbsf at this site reflect typical changes associated with organic carbon cycling (Fig. F17). Sulfate concentrations decrease almost linearly from the seafloor to the sulfate-methane transition zone (SMTZ) at $\sim 13$ mbsf. Alkalinity increases from the seawater value at the seafloor to a maximum of $36 \mathrm{mM}$ at 24 mbsf. Likewise, ammonium concentrations increase in the zone of active $\mathrm{SO}_{4}$ reduction and reach a local maximum of $\sim 4.5 \mathrm{mM}$ below the SMTZ at $24 \mathrm{mbsf}$, reflecting ongoing organic matter diagenesis. Calcium concentrations decrease from a seawater value at the seafloor to $\sim 2.5 \mathrm{mM}$ in this zone, reflecting precipitation of authigenic carbonates. The highest methane concentrations were observed just below the SMTZ between 14.1 and 23.6 mbsf. The gas at these depths results from biogenic production, as indicated by the high ratio of methane to heavier homologs (ethane and propane), with $\mathrm{CH}_{4} /\left(\mathrm{C}_{2} \mathrm{H}_{6}+\right.$ $\mathrm{C}_{3} \mathrm{H}_{8}$ ) values ranging from 8,000 to 15,000 (Fig. F19). Except perhaps for the sample recovered at 68.2 mbsf, in the interval from 20.7 to 200 mbsf, the $\mathrm{CH}_{4} /$ $\left(\mathrm{C}_{2} \mathrm{H}_{6}+\mathrm{C}_{3} \mathrm{H}_{8}\right)$ ratio steadily decreases and is interpreted as a mixing zone between shallow biogenic and deep-sourced thermogenic gas transported upward by diffusion.

Between 40 and 60 mbsf, a marked discontinuity is characterized by a decrease in alkalinity that likely reflects carbonate precipitation. From 100 to $\sim 440$ mbsf, salinity, $\mathrm{Cl}, \mathrm{Mg}, \mathrm{K}$, and $\mathrm{Na}$ concentrations show a monotonic decrease with depth (Fig. F18). Dissolved calcium concentrations are variable to 
200 mbsf and then increase with depth to a peak concentration of $\sim 10 \mathrm{mM}$ at $440 \mathrm{mbsf}$ that is coincident with minima of 390,9 , and $4 \mathrm{mM}$ in $\mathrm{Cl}, \mathrm{Mg}$, and $\mathrm{K}$ concentrations, respectively. The $\mathrm{Cl}, \mathrm{Mg}$, and $\mathrm{K}$ concentrations at $440 \mathrm{mbsf}$ are $67 \%, 17 \%$, and $38 \%$ of seawater values, respectively. Collectively, the pore fluid chemical profiles suggest that a unique fluid exists between 420 and 500 mbsf characterized by relatively low salinity, $\mathrm{Cl}, \mathrm{Mg}, \mathrm{K}$, and alkalinity concentrations and elevated $\mathrm{Ca}$ concentrations. This depth interval also corresponds to a marked increase in thermogenic hydrocarbons (propane, $n$-butane, and iso-butane; Figs. F19, F20). The in situ temperature at this depth (see "Physical properties") is too cold for local generation of thermogenic hydrocarbons, suggesting lateral migration of a fluid sourced in a region with temperatures high enough to support clay dehydration and thermogenic hydrocarbon production.

The three samples recovered below 500 mbsf show a steep gradient with depth in salinity and chloride (Fig. F18), indicating diffusional communication with another fluid below the cored section. Since the $\mathrm{Cl}$ and salinity profiles decrease below $500 \mathrm{mbsf}$, this fluid must be fresher than the deeper sourced fluid sampled between 420 and 500 mbsf. Ethane, propane, iso-butane, and $n$-butane all show a maximum at 518.7 mbsf. The increasing concentrations and maxima of these longer chain hydrocarbons $\left(\mathrm{C}_{2+}\right)$ and the $\mathrm{CH}_{4} /\left(\mathrm{C}_{2} \mathrm{H}_{6}+\mathrm{C}_{3} \mathrm{H}_{8}\right)$ ratios indicate the dominance of thermogenic gas at depth in Hole U1378B.

\section{Microbiology}

Microbiological sampling consisted of $5 \mathrm{~cm}$ wholeround samples cut on the catwalk and subsampled in the laboratory using sterile techniques. Whole-round samples were taken at a frequency of two per core during APC coring of Hole U1378B and once every 10 cores during XCB coring. The deepest sample was taken from Core 334-U1378B-60X at $\sim 500$ mbsf. Whole-round samples were not collected from deeper cores because of poor recovery. Subsampling of the whole-round samples was performed for three different categories of postcruise studies: (1) frozen samples for molecular analyses, (2) refrigerated samples for cultivation studies, and (3) paraformaldehyde-fixed samples for cell counting and contamination testing.

Fixed samples for cell counting were further prepared on ship with a SYBR Green I staining procedure; and enumeration estimates revealed cell concentrations ranging from $9 \times 10^{6}$ to $6 \times 10^{7} \mathrm{cells} / \mathrm{cm}^{3}$, generally declining with depth (Fig. F21). Data have lots of scatter; however, there is one sample with significantly higher cell counts at the depth corresponding to the SMTZ (Fig. F22). Contamination was assessed qualitatively in XCB cores using fluorescent microspheres. These revealed at least some drill fluid contamination of XCB-cored sediment in the center of the core; therefore, all analyses on $\mathrm{XCB}$ samples will have to be interpreted accordingly. Cell enumeration estimates became increasingly unreliable with great depth, and those from depths below 250 mbsf were not included in this analysis.

\section{Physical properties}

At Site U1378, physical properties measurements provide basic information characterizing lithostratigraphic units. After sediment cores reached thermal equilibrium with ambient temperature at $\sim 20^{\circ} \mathrm{C}$, gamma ray attenuation (GRA) density, magnetic susceptibility, and $P$-wave velocity were measured using the Whole-Round Multisensor Logger (WRMSL) on whole-round core sections. After WRMSL scanning, the whole-round sections were logged for natural gamma radiation (NGR). Thermal conductivity was measured using the full-space method on sediment cores and the half-space method on split lithified sediment cores. A photo-image-capture logger and a color spectrophotometer were used to collect images of the split surfaces of the archive-half cores on the Section Half Imaging Logger and the Section Half Multisensor Logger (SHMSL), respectively. Discrete $P$ wave measurements were made on split sediment cores using the Section Half Measurement Gantry (SHMG). Moisture and density (MAD) were measured on discrete subsamples collected from the working halves of the split sediment cores.

\section{Density and porosity}

Bulk density values at Site U1378 were determined from both GRA measurements on whole cores and mass/volume measurements on discrete samples from the working halves of split cores (see "Physical properties" in the "Methods" chapter [Expedition 334 Scientists, 2012]). Samples were chosen from relatively undisturbed portions and preferentially in clay sediments rather than silty or sandier sections. A total of 366 discrete samples were analyzed for MAD. In general, wet bulk density values determined from whole-round GRA measurements agree with measurements from discrete samples (Fig. F23A). Wet bulk density values increase with depth. This increase is likely due to dewatering caused by overbur- 
den pressure and is well described by a linear trend. A small offset in wet bulk density values marks the boundary between lithostratigraphic Units I and II.

Grain density measurements were determined from mass/volume measurements on discrete samples. Grain density values are relatively constant with depth with an average value of $2.69 \mathrm{~g} / \mathrm{cm}^{3}$; however, variability in Unit II is large, with values between $\sim 2.5$ and $2.9 \mathrm{~g} / \mathrm{cm}^{3}$ (Fig. F23B). No discernible offset is apparent between values characterizing lithostratigraphic Units I and II. On the whole, these values suggest terrigenous composition.

Porosity values (see "Physical properties" in the "Methods" chapter [Expedition 334 Scientists, 2012]) were determined from mass/volume measurements on discrete samples using MAD Method C. Porosity is inversely correlated with bulk density and decreases from $\sim 70 \%$ at the seafloor to $40 \%$ at the bottom of the hole (Fig. F23C). A slight increase in porosity between Units I and II corresponds to the decrease in wet bulk density at this boundary. An increase of porosity observed at $\sim 440$ mbsf corresponds to a sandy interval. Porosity increases a few percent between $\sim 480$ and 529 mbsf and may correspond to a decrease in clay content (see "Lithostratigraphy and petrology").

\section{Magnetic susceptibility}

Volumetric magnetic susceptibilities were measured using the WRMSL, and point measurements were made on the SHMSL for all recovered cores from Site U1378. Uncorrected values of magnetic susceptibility are presented (Fig. F24). Magnetic susceptibility values measured with these two methods are in good agreement. In general, magnetic susceptibility in the sedimentary sequence is low, indicating an abundance of non-iron-bearing clays. However, a region of generally higher values lies between $\sim 85$ and 195 mbsf, with maximum values $<0.5$ SI. Other notable regions of relatively high values occur at 335,355 , 440, and 460 mbsf. These excursions exhibit high wave number variability and may be due to lithologic variations between sand, silt, and clay (see "Lithostratigraphy and petrology").

\section{Natural gamma radiation}

NGR results are reported in counts per second (cps; Fig. F25). NGR counting intervals were $\sim 10 \mathrm{~min}$ per whole-core interval. Despite the short counting time, NGR counts are considered reliable.

NGR counts have a mean and standard deviation of 21 and 5 cps, respectively. NGR counts show a small positive trend through lithostratigraphic Unit I and are relatively constant through Unit II. Notable excursions to higher values in Unit II occur at 200 and 480 mbsf. These lowermost NGR highs are associated with scoria (see "Lithostratigraphy and petrology").

\section{P-wave velocity}

Unconfined measurements of $P$-wave velocity at Site U1378 were determined from measurements on sediment whole cores and on discrete samples from the working halves of sediment split cores (see "Physical properties" in the "Methods" chapter [Expedition 334 Scientists, 2012]). Whole-core $P$-wave velocity measurements at this site only produced useful results above 20 mbsf and again between 270 and 440 mbsf (Fig. F26). Based on visual inspection of the core, the unreliable measurements are attributed to the low water content of the clays. The $P$-wave signal does not seem to penetrate through relatively dry clays. Comparisons between these measurements and measurements taken on empty core liners suggest that the signal travels within the plastic liner around the core instead of through the recovered material, resulting in unrealistically low velocities. Between 270 and $440 \mathrm{mbsf}$, SHMG measurements of $P$-wave velocity along the $z$-axis are $\sim 1700 \mathrm{~m} / \mathrm{s}$.

\section{Thermal conductivity}

Thermal conductivity measurements were conducted on sediment whole-round cores using the needle-probe method and on lithified split cores using the half-space method (see "Physical properties" in the "Methods" chapter [Expedition 334 Scientists, 2012]). In general, thermal conductivity increases with depth and is inversely correlated to porosity (Fig. F27). In the uppermost 100 mbsf, variability is significant and likely reflects gas concentrations in the core. Between 260 and 310 mbsf, both needle-probe and half-space measurements of thermal conductivity were made. In general, needleprobe values are lower and likely reflect cracking in the core as the needle was inserted. Half-space values of thermal conductivity show less scatter than needle-probe values.

\section{Downhole temperature}

Downhole temperature was measured using the APCT-3. Four measurements were made between 34 and 110 mbsf in Hole U1378B (Table T7; Fig. F27). All measurements were made in lithostratigraphic Unit I. The Sediment Temperature Tool was not used at this site.

All measurements were made in a good sea state $(<1 \mathrm{~m}$ swell), and all temperature-time series were recorded 
with a sample interval of $1 \mathrm{~s}$. The temperature tool was stopped at the mudline for as long as $10 \mathrm{~min}$ prior to each penetration. The average bottom water temperature is $22.6^{\circ} \mathrm{C}$ (Table T7). Temperature-time series for each temperature measurement are shown in Figure F28. Significant frictional heating occurred on all penetrations of the APCT-3, with the temperature-time records exhibiting characteristic probe penetration and subsequent decay. Tool movement while the probe was in the sediment is minimal with the exception of Core 334-U1378B-3H, which indicates slight movement at about the 5 min mark. The effective origin time of the frictional heat pulse was estimated by varying the assumed origin time until the thermal decay pulse best fit a theoretical curve. All of the measurements appear to be reliable. Equilibrium temperatures plotted as a function of depth are relatively linear; coupled with the average bottom water temperature, they give a least-squares gradient of $51.4^{\circ} \mathrm{C} / \mathrm{km}$ (Fig. F27).

\section{Heat flow}

Because thermal conductivity appears relatively constant over the depth of temperature measurements, we compute the heat flow as the product of the thermal gradient and thermal conductivity. Using the mean thermal conductivity of $0.86 \mathrm{~W} /(\mathrm{m} \cdot \mathrm{K})$ gives a heat flow of $44 \mathrm{~mW} / \mathrm{m}^{2}$. This value is consistent with forearc values of heat flow.

If heat transfer is by conduction and heat flow is constant, the thermal gradient will be inversely proportional to thermal conductivity according to Fourier's law. This relationship can be linearized by plotting temperature as a function of summed thermal resistance (Bullard, 1939),

$$
T(z)=T_{\mathrm{o}}+q \times \Sigma\left[\Delta z_{\mathrm{i}} / k(z)_{\mathrm{i}}\right], i=1: N,
$$

where

$$
\begin{aligned}
& T=\text { temperature } \\
& Z=\text { depth, } \\
& T_{\mathrm{o}}=\text { bottom water temperature, } \\
& q=\text { heat flow, and } \\
& {\left[\Delta Z_{\mathrm{i}} / k(Z)_{\mathrm{i}}\right]=\text { thermal resistance. }}
\end{aligned}
$$

We assume a linear increase of thermal conductivity with depth and extrapolate temperatures to the sediment/basement interface (Fig. F27). The estimated temperature at this depth is $31^{\circ} \mathrm{C}$.

\section{Vane shear}

Undrained shear strengths increase approximately linearly with depth through lithostratigraphic Unit I to a maximum value of $154 \mathrm{kPa}$ (Fig. F29). At the top of Unit II, vane shear strength decreases and be- comes more erratic. This change in behavior occurs near the depth where the coring method changed from APC to XCB.

\section{Color spectroscopy}

Color reflectance measurement results are presented in Figure F30. $\mathrm{L}^{*}$ values are generally between 10 and 50. $a^{*}$ and $b^{*}$ values are inversely correlated. $a^{*}$ values are generally between -5 and 0 , and those of $b^{*}$ generally vary from -5 to 10 .

\section{Paleomagnetism}

Remanent magnetization was measured on archivehalf cores and on discrete samples taken from the working halves of cores recovered in Hole U1378B. All archive-half cores were demagnetized in an alternating field (AF) to $15 \mathrm{mT}$ and measured with the pass-through magnetometer. Discrete samples were subjected to stepwise AF demagnetization and measured in both the superconducting rock magnetometer and JR6 magnetometer. Cores 334-U1378B-1H through $16 \mathrm{H}$ were cored with the APC system using a nonmagnetic cutting shoe and oriented with the Flexit orientation tool. Cores $17 \mathrm{X}$ through $63 \mathrm{X}$ were cored with the XCB system using a standard cutting shoe.

\section{Natural remanent magnetization}

Paleomagnetic data obtained at Site U1378 exhibit significant variations in demagnetization behavior among various recovered lithologies. Drilling-induced remagnetization pervasively exists in the recovered cores (Fig. F31). The mean natural remanent magnetization (NRM) intensity varies downhole in three trends:

- NRM intensity for the uppermost 80 mbsf is on the order of $10^{-1} \mathrm{~A} / \mathrm{m}$;

- For sediments at $~ 90-190$ mbsf, NRM intensity is strongest, ranging from $10^{-2}$ to $5 \times 10^{-2} \mathrm{~A} / \mathrm{m}$; and

- Mean NRM intensity for 190-300 mbsf is $\sim 10^{-2} \mathrm{~A} / \mathrm{m}$, whereas intensities at 300-400 mbsf vary on the order of $10^{-3}$ to $10^{-1} \mathrm{~A} / \mathrm{m}$ (Fig. F31).

NRM intensity variations through cored units are closely correlated with those in magnetic susceptibility measurements. Like the NRM record, distinct increases in magnetic susceptibility are present at $~ 90$ 190 mbsf (see "Physical properties").

\section{Demagnetization behavior of APC cores}

The steep downward component of magnetization imparted by the coring process is easily removed by 
AF demagnetization (Figs. F31, F32A, F32B). Declinations determined by the pass-through measurements are uniform within each core, except for the core ends where coring-related disruptions are usually present (Fig. F33A). After making the orientation correction, using data from the Flexit tool, declinations become close to magnetic north, with exceptions in Cores 334-U1378B-4H and 10H (Fig. F33B), indicating the remanence is of geomagnetic origin.

The magnetic properties observed from the split cores were also confirmed by discrete sample measurements. The nearly vertical overprint was removed by AF demagnetization of 5-10 $\mathrm{mT}$, and the stable component has a similar direction to those in the corresponding core sections (red stars in Fig. F31). No clear reversal was observed in the magnetic records of the APC cores.

\section{Demagnetization behavior of XCB cores}

Steep inclinations imparted by XCB drilling at Site U1378 are extremely stable and resistant to AF demagnetization (Figs. F31B, F32C, F32D). NRM of the $\mathrm{XCB}$ cores is also oriented parallel to the $+x$-direction, with declinations tightly clustered at $0^{\circ}$, indicating the existence of a radially inward magnetization induced by the coring process (e.g., Stokking et al., 1993). We performed progressive AF demagnetization experiments on discrete samples. All samples showed rapid removal of near-vertical overprint at 5-15 mT demagnetization steps, but several samples are either completely dominated by the artificial overprint or indicate scattered demagnetization behavior (e.g., Fig. F32D). Out of 119 discrete samples, 62 discrete samples revealed behavior indicating the successful removal of the radial overprint. The inclinations of the characteristic remanent magnetization (ChRM) are close to the theoretically expected latitude of this site (red stars in Fig. F31). The success of AF demagnetization appears to be dependent on stratigraphic position. For example, virtually all samples from depth intervals to $100 \mathrm{mbsf}$ revealed ChRM, while those from $\sim 300$ or $\sim 420$ mbsf completely failed to reveal ChRM.

\section{Rock magnetic characterization}

High NRM intensity values at $~ 90-190$ mbsf may reflect a higher magnetic mineralogy content and correlations with other physical signatures. AF demagnetization experiments suggest that samples from this interval also have higher magnetic stability than other intervals in Hole U1378B (Fig. F33B). To further characterize the magnetic mineralogy in this interval, we conducted several rock magnetic experiments on selected samples within (Sample 334-
U1378B-15H-3, 63-65 cm), above (Sample 5H-2, 104-106 cm), and below (Sample 32X-2, 94-96 cm) this interval. These experiments include acquisitions of isothermal remanent magnetization (IRM) and anhysteretic remanent magnetization (ARM), followed by AF demagnetization of IRM and ARM. IRM and ARM were acquired by a pulse magnetizer (ASC Scientific, IM10) and the Dtech AF demagnetizer, respectively (see "Paleomagnetism" in the "Methods" chapter [Expedition 334 Scientists, 2012]). For ARM acquisition, we used an AF with peak intensity of $100 \mathrm{mT}$ and a direct current field of $100 \mu \mathrm{T}$. Magnetizations were measured by the JR-6 magnetometer.

As shown in Figure F34A, all three samples revealed rapid saturation of IRM with increasing applied field $(<500 \mathrm{mT})$, suggesting minor contributions of highcoercivity minerals such as hematite and that the magnetic carriers are most likely fine-grained magnetite. Sample 334-U1378B-15H-3, 63-65 cm, displayed strong saturation IRM intensity that was $\sim 30$ times higher than in the other samples. This observation is consistent with the high NRM intensity for sediments at 90-190 mbsf. AF demagnetization experiments indicate moderate stability for all samples (Fig. F34B). Interestingly, the strongly magnetized Sample 334-U1378B-15H-3, 63-65 cm, showed rapid decay of intensity for both IRM and ARM demagnetization. More experimental results are needed before we can conclude if this behavior is generally true for the sediments at $\sim 90-190$ mbsf.

\section{Structural application of core orientation}

For intervals of particular interest for structural geology at Site U1378, the declinations of the stable ChRM were used to help restore the azimuth of the core (see "Structural geology"). We used results from discrete sample demagnetization assuming the direction of stable remanent magnetization (or ChRM) represents the expected magnetic direction at Site U1378.

\section{Magnetostratigraphy}

For APC cores, neither pass-through nor discretesample measurements show signs of reversed polarity. In addition, declination data corrected by the Flexit tool do not show a near- $180^{\circ}$ shift in declinations. Thus, we interpret that the sediments in the APC interval ( 128 mbsf) were deposited within the normal polarity Brunhes period $(<0.78 \mathrm{Ma})$. This age assignment is consistent with the shipboard micropaleontological data, which suggest that the planktonic foraminifer G. ruber pink found between Cores $334-\mathrm{U} 1378 \mathrm{~B}-4 \mathrm{H}$ and $5 \mathrm{H}$ may be $0.12 \mathrm{Ma}$ in age (see "Paleontology and biostratigraphy"). Nannofossil 
records also suggest that Cores $1 \mathrm{H}$ through $32 \mathrm{X}$ should be of late Pleistocene age, further corroborating with the notion that the sediment with this depth interval is younger than 0.78 Ma.

On the basis of biostratigraphic data, Zone NN19 of the early Pleistocene is tentatively placed at $\mathrm{XCB}$ Cores 334-U1378B-33X through 63X (see "Paleontology and biostratigraphy"). Paleomagnetic measurements made on the XCB cores so far have not revealed any reversed polarity for sediments in Hole U1378B. Additional shore-based work is required to check or confirm the shipboard data.

\section{Downhole logging}

\section{Logging-while-drilling operations}

Hole U1378A was drilled and logged with a Schlumberger LWD tool string that included (from top to bottom) the adnVISION 675 (density, neutron porosity, and ultrasonic caliper), the TeleScope 675 (measurement while drilling, power and data transmission and drilling parameters), the arcVISION 675 (propagation resistivity, gamma radiation, and annular pressure), and the geoVISION 675 (resistivity images and gamma radiation). The LWD tools were $63 / 4$ inch diameter versions in a BHA with an $81 / 2$ inch bit and $6 \frac{1}{2}$ inch drill collars. For details, see "Downhole logging" in the "Methods" chapter (Expedition 334 Scientists, 2012).

During logging in Hole U1378A, the LWD tools were run without batteries, which did not reach Puntarenas before the R/V JOIDES Resolution sailed. The LWD tools were powered only by the mud turbine generator in the TeleScope. The main negative implications of running the LWD tools without batteries are that (1) no data are taken when the flow rate is less than the minimum required to power up the tools $(\sim 300$ $\mathrm{gal} / \mathrm{min}$ or $18.9 \mathrm{~L} / \mathrm{s}$ ) and (2) if the tools lose connection to the TeleScope their clock may be reset, which requires postcruise processing. The missing batteries, however, do not affect data collection during drilling, when pumps are on. The batteries were eventually delivered to the JOIDES Resolution by helicopter a day after operations started in Hole U1378A and were installed in the LWD tools used in Hole U1379A.

Hole U1378A was spudded at $537 \mathrm{~m}$ drilling depth below rig floor (DRF) at $0420 \mathrm{~h}$ on 18 March 2011 (all times are local Costa Rica time; UTC - 6 h). Drilling proceeded smoothly in the uppermost $300 \mathrm{~m}$ at total drilling rates of $\sim 25 \mathrm{~m} / \mathrm{h}$ (total drilling rates include time for connections). Drilling became more difficult at 300-450 mbsf, where rates dropped to an average of $\sim 13 \mathrm{~m} / \mathrm{h}$. After the bit reached a depth of
455 mbsf at $\sim 0500 \mathrm{~h}$ on $19 \mathrm{March}$, the drillers noted high standpipe pressures and backflow when making connections, indicating hole cleaning problems. Also, the top drive torque showed occasional large increases. The bit was lifted off the bottom, and the hole was repeatedly backreamed to improve circulation. These attempts continued for several hours. High standpipe pressures and top drive torques were consistently observed when the bit was deeper than $\sim 850 \mathrm{~m}$ DRF (313 mbsf). After many attempts to return to the bottom of the hole, in the afternoon of 19 March the bit was still $\sim 100 \mathrm{~m}$ above the total depth reached early in the morning. It was recognized that progress was too slow to significantly deepen the hole before the JOIDES Resolution would have to move to the next site, and at $1720 \mathrm{~h}$ it was decided to stop drilling in Hole U1378A, gaining a few hours for LWD at the next site.

Measurements recorded by the LWD tools were downloaded and processed without difficulties, except for the geoVISION resistivity image data. The Schlumberger logging engineers noted that the azimuthal orientation system of the geoVISION tool malfunctioned, and they sent the geoVISION data recorded in Hole U1378A to a Schlumberger LWD data processing center in Houston, Texas (USA). This attempt was unsuccessful, and no geoVISION resistivity image data are available for Hole U1378A. The geoVISION log measurements of resistivity and NGR, which do not rely on measuring tool orientation, were collected successfully.

\section{Gas monitoring with logging-while-drilling measurements}

As the first hole at Site U1378 was drilled with LWD, the LWD data had to be monitored for safety to detect gas entering the wellbore. As explained in "Downhole logging" in the "Methods" chapter (Expedition 334 Scientists, 2012), the primary measurement we used in gas monitoring was the annular pressure measured while drilling by the arcVISION tool and transmitted in real time to the surface. We looked for sustained decreases of $>30-50$ psi in the annular pressure, which could caused by low-density gas entering the wellbore.

Figure F35 shows residual pressure that is the measured annular pressure minus the hydrostatic pressure (for a seawater density of $1025 \mathrm{~kg} / \mathrm{m}^{3}$ ). From the seafloor to $340 \mathrm{mbsf}$, the observed annular pressure was very close to hydrostatic. The large downhole pressure fluctuations (100 psi and greater) observed below 340 mbsf are likely due to cuttings restricting flow in the borehole annulus, which required backreaming and hole cleaning in this interval and eventually led to abandoning the hole. These pressure 
fluctuations consisted of an increase followed by a decrease to the overall pressure trend as hole cleaning progressed. The pressure trend in this interval was higher than hydrostatic because of solid particles that increase the effective density of the borehole fluid. No sustained pressure drops below the general trend that exceeded the 30-50 psi threshold set in the monitoring protocol and that could be due to gas entry were observed, and no drilling interruptions were necessary.

\section{Logging data quality}

Figure F35 also shows the quality control logs for Hole U1378A. A major control on LWD measurement quality is the borehole size, which is obtained by the adnVISION tool from the difference between the short- and long-spaced density measurements and from an ultrasonic traveltime measurement. Figure F35 shows the average borehole diameters estimated from these measurements. The most reliable measurement of borehole diameter is the ultrasonic caliper, which shows enlarged hole intervals (10-12 inches; $25-30 \mathrm{~cm}$ ) from the seafloor to 90 mbsf and at 290-310 and 340-370 mbsf. The density correction, which is also calculated from the difference between the short- and long-spaced density measurements, generally varies from 0 to $0.1 \mathrm{~g} / \mathrm{cm}^{3}$. This correction, however, did not result in accurate density values in some enlarged hole intervals, where the measured LWD densities were anomalously low (see the comparison to core data below).

The average instantaneous rate of penetration (ROP) was $\sim 100 \mathrm{~m} / \mathrm{h}$ between the seafloor and $30 \mathrm{mbsf}$, decreasing to $\sim 40 \mathrm{~m} / \mathrm{h}$ to $300 \mathrm{mbsf}$ and $20-40 \mathrm{~m} / \mathrm{h}$ below 300 mbsf. This ROP is the rate of penetration of the LWD tools while the hole is being drilled and does not include time for pipe connections. The quality of the geoVISION resistivity image is best for ROPs of $\sim 20 \mathrm{~m} / \mathrm{h}$, and while drilling Hole U1378A, some resolution in the shallowest interval was traded for drilling time. Previous experience shows that high-quality geoVISION resistivity images can be acquired at ROPs as high as those employed while drilling Hole U1378A (e.g., Cook et al., 2009; Guerin et al., 2009). No geoVISION resistivity image data are available for Hole U1378A, however, and the possible effect of ROP on the resistivity image quality cannot be assessed.

The depths relative to seafloor were fixed for all LWD logs by identifying the step change in the gamma ray and density logs associated with the seafloor. For Hole U1378A, the logging pick for the seafloor was at 532 mbrf, $\sim 5 \mathrm{~m}$ above the seafloor depth estimated by the drillers. The rig floor logging datum was at 9.8 mbsl.

\section{Characterization of logging-while-drilling logs}

Figure F36 is a summary of the LWD logs and images measured in Hole U1378A. The two density curves are conventional bulk density (RHOB) and density estimated from the adnVISION azimuthal measurements to minimize the effect of sensor standoff (image-derived density [IDRO]). These two density measurements give very similar values. Figure F36 also shows a density porosity $(\phi)$ computed from the IDRO bulk density $\rho_{\mathrm{b}}$ as

$$
\phi=\left(\rho_{g}-\rho_{b}\right) /\left(\rho_{g}-\rho_{w}\right),
$$

where $\rho_{w}$ is the water density and $\rho_{g}$ the grain density. The density porosity curve in Figure F36 is calculated assuming a water density of $1.025 \mathrm{~g} / \mathrm{cm}^{3}$ and a grain density of $2.65 \mathrm{~g} / \mathrm{cm}^{3}$.

The comparison of density porosity and neutron porosity in Figure F36 shows that neutron porosity is always higher. As noted in "Downhole logging" in the "Methods" chapter (Expedition 334 Scientists, 2012), the likely reason for the higher porosity measured by the neutron log is the presence of clay minerals. The hydrogen in the clay mineral hydroxyls contributes to the slowing down of neutrons and increases the estimated porosity (Ellis, 1986). Density porosity is the more accurate measure of porosity in sediments containing appreciable amounts of clay.

Figure F36 also shows a high vertical resolution resistivity measured by the ring electrode in the geoVISION tool and two propagation resistivity curves that span the resolution of the resistivities measured by the arcVISION tool. These propagation resistivities are based on the attenuation and phase shifts of electromagnetic waves that travel through the formation (see "Downhole logging" in the "Methods" chapter [Expedition 334 Scientists, 2012] for details). The two propagation resistivity curves in Figure F36 are the relatively low vertical resolution A40B, based on the attenuation measured at a transmitter-receiver separation of 40 inches $(101.6 \mathrm{~cm})$, and the high-resolution P16B, based on the phase shift measured at a transmitter-receiver separation of 16 inches $(40.6 \mathrm{~cm})$. The " $\mathrm{B}$ " in the acronym is for "blended," because these curves include measurements at the two electromagnetic wave frequencies used by the tool $(400 \mathrm{kHz}$ and $2 \mathrm{MHz}$ ).

To a first approximation, the resistivity in a sediment sequence is controlled by the porosity. The sediment grains are effectively insulators, and the medium that conducts electricity is saline water in the pore network. This implies a close inverse relationship between resistivity and sediment porosity and a direct relationship between resistivity and bulk density. 
These relationships are evident in Figure F36, with the exception of a few intervals where the logged densities show large negative peaks without corresponding drops in resistivity (e.g., 295-310 mbsf). This difference could be due to a measured log density that is too low in enlarged hole intervals (see the hole diameter logs in Fig. F35) and is discussed below, taking also into account core measurements.

Finally, Figure F36 shows two images of bulk density and borehole radius measured by the adnVISION tool. The image display is highly compressed in the vertical direction. For a 10 inch $(25.4 \mathrm{~cm})$ diameter borehole, the unwrapped borehole images are $\sim 80$ $\mathrm{cm}$ wide, and the vertical scale is compressed by a factor of 70:1 in the images of Figure F36.

These images are obtained by azimuthal measurements in 16 sectors and thus are sampled at a relatively coarse interval of $22.5^{\circ}$. Because of their limited angular resolution, these images typically do not resolve fine-scale sedimentary or structural features. On the other hand, the radius image clearly displays vertical bands of large borehole radius, which are typically interpreted as borehole breakouts caused by differences in the principal horizontal stresses (e.g., Chang et al., 2010). Borehole breakouts in Hole U1378A are analyzed below.

\section{Logging units}

We define two logging units on the basis of the variation in logging properties displayed in Figure F36. Logging Unit 1 (0-82 mbsf) corresponds to a compacting sequence with a well-defined increase in density and resistivity and a corresponding porosity decrease with depth. The densities logged in this unit show some fluctuations over an increasing trend with depth, from 1.4 to $1.6 \mathrm{~g} / \mathrm{cm}^{3}$. The resistivity log displays a similar increasing trend with depth from $0.5 \Omega \mathrm{m}$ at the seafloor to $1.0 \Omega \mathrm{m}$ at the base of the unit. Porosity starts at $70 \%-80 \%$ at the seafloor and decreases to $60 \%$ at the base of this unit. The NGR log also shows an increase with depth from the seafloor ( 25 gAPI) to the base of the unit ( 40 gAPI).

The top of logging Unit 2 (82-455 mbsf) is marked by a step increase of density and resistivity, which show only small increases with depth in this unit. Density increases from $\sim 1.8 \mathrm{~g} / \mathrm{cm}^{3}$ at the top to $\sim 1.9$ $\mathrm{g} / \mathrm{cm}^{3}$ at the base and resistivity from just above 1 $\Omega \mathrm{m}$ at the top to just below $2 \Omega \mathrm{m}$ at the base. Porosity shows a matching small decrease with depth, from 55\% at the top of logging Unit 2 to $45 \%$ at the base. The NGR log shows nearly constant values (40 gAPI) at 82-190 mbsf, a positive excursion up to 70
gAPI at 190-196 mbsf, a gradual decrease with depth from 50 to 40 gAPI at $196-330 \mathrm{mbsf}$, and then a constant $\sim 40$ gAPI at 330-455 mbsf. The gamma ray peak at 190-196 mbsf is matched by a peak in the core measurements (see the next section) and corresponds to a sandy interval containing black organic matter particles in Core 334-U1378B-24X (see "Lithostratigraphy and petrology").

Superimposed over the steady increase of density with depth, the logged values show large density fluctuations with sharp negative peaks at 295-310 and 355-370 mbsf caused by borehole enlargements (see the hole diameter logs in Fig. F35). These enlargements are likely to correspond to intervals containing unconsolidated sands or fractured intervals, which are prone to washout during drilling. For example, a negative excursion in the density log at 355-370 mbsf corresponds to fractured and brecciated zones observed in Cores 334-U1378B-44X through 46X (see "Structural geology").

\section{Borehole breakout analyses}

Borehole breakout analyses were performed to assess the orientation of the present-day maximum horizontal stress within the borehole. Breakout features appear as two vertical dark bands in both density and radius images from Hole U1378A (Fig. F36). The borehole radius images were used to identify the breakout morphology. No obvious breakouts are identified from the seafloor to 110 mbsf. Breakouts occur discontinuously as two well-developed vertical bands of large borehole radius separated by $180^{\circ}$ in the interval between $110 \mathrm{mbsf}$ and the bottom of the radius image (438 mbsf). The widths of these breakouts are variable and generally range from $20^{\circ}$ to $90^{\circ}$. Breakouts are typically developed in the northeastsouthwest to east-northeast-west-southwest direction with a range of three sectors $\left(22.5^{\circ}-90^{\circ}\right)$, indicating that the maximum horizontal stress at Site U1378 is oriented northwest-southeast to northnorthwest-south-southeast. An exception is from 239 to $252 \mathrm{mbsf}$, where the breakouts are oriented northeast-southwest to north-northeast-southsouthwest. Although breakouts are typically fragmented in segments of $0.5-5 \mathrm{~m}$ vertical length, continuous breakout intervals occur at 218-230, 241252, 256-280, 395-406, and 410-433 mbsf (Fig. F37). Breakouts are wider and display disrupted structure at 294-311 and 334-375 mbsf, in coincidence with borehole enlargements indicated by the caliper logs (Fig. F35). The disrupted interval at 334375 mbsf approximately corresponds to brecciated and fractured zones described in Cores 334-U1378- 
44X through 46X (see "Structural geology"). Detailed statistical analyses of breakout azimuths and widths will be conducted postexpedition.

\section{Core-log integration}

Figure F38 is a comparison of NGR, bulk density, and porosity measurements made by LWD in Hole U1378A and in core samples in Hole U1378B. This comparison is useful to correlate depths in the LWD logs and depths of core samples and to integrate information from log and core measurements.

NGR log measurements are calibrated to a degree API (gAPI) scale by comparison to a standard artificial formation built to simulate about twice the radioactivity of a typical shale and conventionally set to 200 gAPI (Ellis and Singer, 2007). The NGR measurement made on whole-core sections on the JOIDES Resolution is in counts per second (for a detailed description of the NGR apparatus, see Vasiliev et al., 2010). The comparison of log and core NGR measurements in Figure F38 shows that their curves overlap if $1 \mathrm{cps}$ equals $\sim 2$ gAPI. Occasionally, low NGR values are measured at the end of core sections. To avoid these end effects, measurements from the uppermost and lowermost $10 \mathrm{~cm}$ of each section have been excluded from the NGR data plotted in Figure F38. Most patterns in the log and core NGR records match closely, with only a few depth shifts likely caused by collection of data in different holes and by uncertainties in the depth measurement (e.g., the depth difference in the broad peak in NGR and logged values at 190-200 mbsf). This general agreement indicates a close correlation in the depths of the log and core records.

Figure F38 also compares IDRO bulk density logs to densities measured on whole-core sections by GRA and on discrete core samples by MAD analysis. The bulk density values are generally comparable, with the exception of several intervals where the log densities are clearly higher than the core densities and the corresponding logged porosities are unrealistically high (e.g., density lows $<1.4 \mathrm{~g} / \mathrm{cm}^{3}$ at $350-375$ mbsf). These extremely low logged density values are likely caused by borehole enlargements.

An interesting interval in this bulk density comparison is between 110 and 200 mbsf, where core densities are systematically lower than logged densities. The differences are as much as $0.2 \mathrm{~g} / \mathrm{cm}^{3}$, or $\sim 11 \%$ of the bulk density. A contributing factor to this difference may be core expansion by elastic rebound (Moran, 1997), as many cores in this depth interval showed $>100 \%$ recovery. The MAD porosities are density porosities calculated with the measured grain densities in each sample. As the MAD densities in this interval are slightly lower than the log densi- ties, the MAD porosities are slightly higher than the porosities computed from the density log.

\section{References}

Berggren, W.A, Hilgen, F.J., Langereis, C.G., Kent, D.V., Obradovich, J.D., Raffi, I., Raymo, M.E., and Shackelton, N.J., 1995a. Late Neogene chronology: new perspectives in high-resolution stratigraphy. Geol. Soc. Am. Bull., 107(11):1272-1287. doi:10.1130/00167606(1995)107<1272:LNCNPI>2.3.CO;2

Berggren, W.A., Kent, D.V., Swisher, C.C., III, and Aubry, M.-P., 1995b. A revised Cenozoic geochronology and chronostratigraphy. In Berggren, W.A., Kent, D.V., Aubry, M.-P., and Hardenbol, J. (Eds.), Geochronology, Time Scales and Global Stratigraphic Correlation. Spec. Publ.-SEPM (Soc. Sediment. Geol.), 54:129-212.

Bullard, E.C., 1939. Heat flow in South Africa. Proc. R. Soc. London, Ser. A, 173(955):474-502. doi:10.1098/ rspa.1939.0159

Chang, C., McNeill, L.C., Moore, J.C., Lin, W., Conin, M., and Yamada, Y., 2010. In situ stress state in the Nankai accretionary wedge estimated from borehole wall failures. Geochem., Geophys., Geosyst., 11:Q0AD04. doi:10.1029/2010GC003261

Cook, A., Guerin, G., Mrozewski, S., Collett, T., and Boswell, R., 2009. Gulf of Mexico gas hydrate joint industry project Leg II-Walker Ridge 313 LWD operations and results. Proc. Drill. Sci. Results 2009 Gulf of Mexico Gas Hydrate Jt. Ind. Proj. Leg II. http:// www.netl.doe.gov/technologies/oil-gas/publications/Hydrates/2009Reports/WR313LWDOps.pdf

Cowan, D.S., 1982. Origin of "vein structure" in slope sediments on the inner slope of the Middle America Trench off Guatemala. In Aubouin, J., von Huene, R., et al., Init. Repts. DSDP, 67: Washington, DC (U.S. Govt. Printing Office), 645-650. doi:10.2973/dsdp.proc.67.132.1982

Ellis, D.V., 1986. Neutron porosity devices-what do they measure? First Break, 4(3):11-17. doi:10.3997/13652397.1986005

Ellis, D.V., and Singer, J.M., 2007. Well Logging for Earth Scientists, (2nd ed.): Dordrecht, The Netherlands (Springer).

Expedition 334 Scientists, 2012. Methods. In Vannucchi, P., Ujiie, K., Stroncik, N., Malinverno, A., and the Expedition 334 Scientists, Proc. IODP, 334: Tokyo (Integrated Ocean Drilling Program Management International, Inc.). doi:10.2204/iodp.proc.334.102.2012

Grevemeyer, I., Kopf, A.J., Fekete, N., Kaul, N., Villinger, H.W., Heesemann, M., Wallmann, K., Spiess, V., Gennerich, H.-H., Muller, M., and Weinrebe, W., 2004. Fluid flow through active mud dome Mound Culebra offshore Nicoya Peninsula, Costa Rica: evidence from heat flow surveying. Mar. Geol., 207(1-4):145-157. doi:10.1016/j.margeo.2004.04.002

Guerin, G., Cook, A., Mrozewski, S., Collett, T., and Boswell, R., 2009. Gulf of Mexico gas hydrate joint industry project Leg II-Green Canyon 955 LWD operations and results. Proc. Drill. Sci. Results 2009 Gulf of 
Mexico Gas Hydrate Jt. Ind. Proj. Leg II. http:// www.netl.doe.gov/technologies/oil-gas/publications/Hydrates/2009Reports/GC955LWDOps.pdf

Harris, R.N., Spinelli, G., Ranero, C.R., Grevemeyer, I., Villinger, H., and Barckhausen, U., 2010. Thermal regime of the Costa Rican convergent margin: 2. Thermal models of the shallow Middle America subduction zone offshore Costa Rica. Geochem., Geophys., Geosyst., 11(12):Q12S29. doi:10.1029/2010GC003273

Hensen, C., Wallmann, K., Schmidt, M., Ranero, C.R., and Suess, E., 2004. Fluid expulsion related to mud extrusion off Costa Rica-a window to the subducting slab. Geology, 32(3):201-204. doi:10.1130/G20119.1

LaFemina, P., Dixon, T.H., Govers, R., Norabuena, E., Turner, H., Saballos, A., Mattioli, G., Protti, M., and Strauch, W., 2009. Fore-arc motion and Cocos Ridge collision in Central America. Geochem., Geophys., Geosyst., 10(5):Q05S14. doi:10.1029/2008GC002181

Martini, E., 1971. Standard Tertiary and Quaternary calcareous nannoplankton zonation. Proc. Second Planktonic Conf. Roma 1970, 2:739-785.

McAdoo, B.G., Orange, D.L., Silver, E.A., McIntosh, K., Abott, L., Galewsky, J., Kahn, L., and Protti, M., 1996. Seafloor structural observations, Costa Rica accretionary prism. Geophys. Res. Lett., 23(8):883-886. doi:10.1029/ 96GL00731

Moran, K., 1997. Elastic property corrections applied to Leg 154 sediment, Ceara Rise. In Shackleton, N.J., Curry, W.B., Richter, C., and Bralower, T.J. (Eds.), Proc. ODP, Sci. Results, 154: College Station, TX (Ocean Drilling Program), 151-155. doi:10.2973/ odp.proc.sr.154.132.1997

Ogawa, Y., 1980. Beard-like veinlet structure as fracture cleavage in the Neogene siltstone in the Miura and Boso peninsulas, central Japan. Sci. Rep. Dept. Geol., Kyushu Univ., 13:321-327.
Ranero, C.R., Grevemeyer, I., Sahling, U., Barckhausen, U., Hensen, C., Wallmann, K., Weinrebe, W., Vannucchi, P., von Huene, R., and McIntosh, K., 2008. Hydrogeological system of erosional convergent margins and its influence on tectonics and interplate seismogenesis. Geochem., Geophys., Geosyst., 9(3):Q03S04. doi:10.1029/ 2007GC001679

Stokking, L., Musgrave, R., Bontempo, D., Autio, W., Rabinowitz, P.D., Baldauf, J., and Francis, T.J.G., 1993. Handbook for shipboard paleomagnetists. ODP Tech. Note, 18. doi:10.2973/odp.tn.18.1993

Vasiliev, M.A., Blum, P., Chubarian, G., Olsen, R., Bennight, C., Cobine, T., Fackler, D., Hastedt, M., Houpt, D., Mateo, Z., and Vasilieva, Y.B., 2011. A new natural gamma radiation measurement system for marine sediment and rock analysis. J. Appl. Geophys., 75(3):455463. doi:10.1016/j.jappgeo.2011.08.008

Wade, B.S., Pearson, P.N., Berggren, W.A., and Pälike, H., 2011. Review and revision of Cenozoic tropical planktonic foraminiferal biostratigraphy and calibration to the geomagnetic polarity and astronomical time scale. Earth-Sci. Rev., 104(1-3):111-142. doi:10.1016/j.earscirev.2010.09.003

Weinrebe, W., and Ranero, C.R. (Eds.), 2003. FS/RV Sonne Cruise Report SO173/2: Seduction, Part A. Seismogenesis and tectonic erosion during subduction: Middle America margin. GEOMAR Rep., 116. http://oceanrep.geomar.de/13407/1/Geomar-Report-116.pdf

Zijderveld, J.D.A., 1967. AC demagnetization of rocks: analysis of results. In Collinson, D.W., Creer, K.M., and Runcorn, S.K. (Eds.), Methods in Palaeomagnetism: Amsterdam (Elsevier), 254-286.

Publication: 12 April 2012

MS 334-103 
Figure F1. Prestack depth-migrated seismic BGR99 Line 7 showing locations of Sites U1378 and U1379 on the middle and upper slope, respectively. $\mathrm{CMP}=$ common midpoint.

Distance (km)

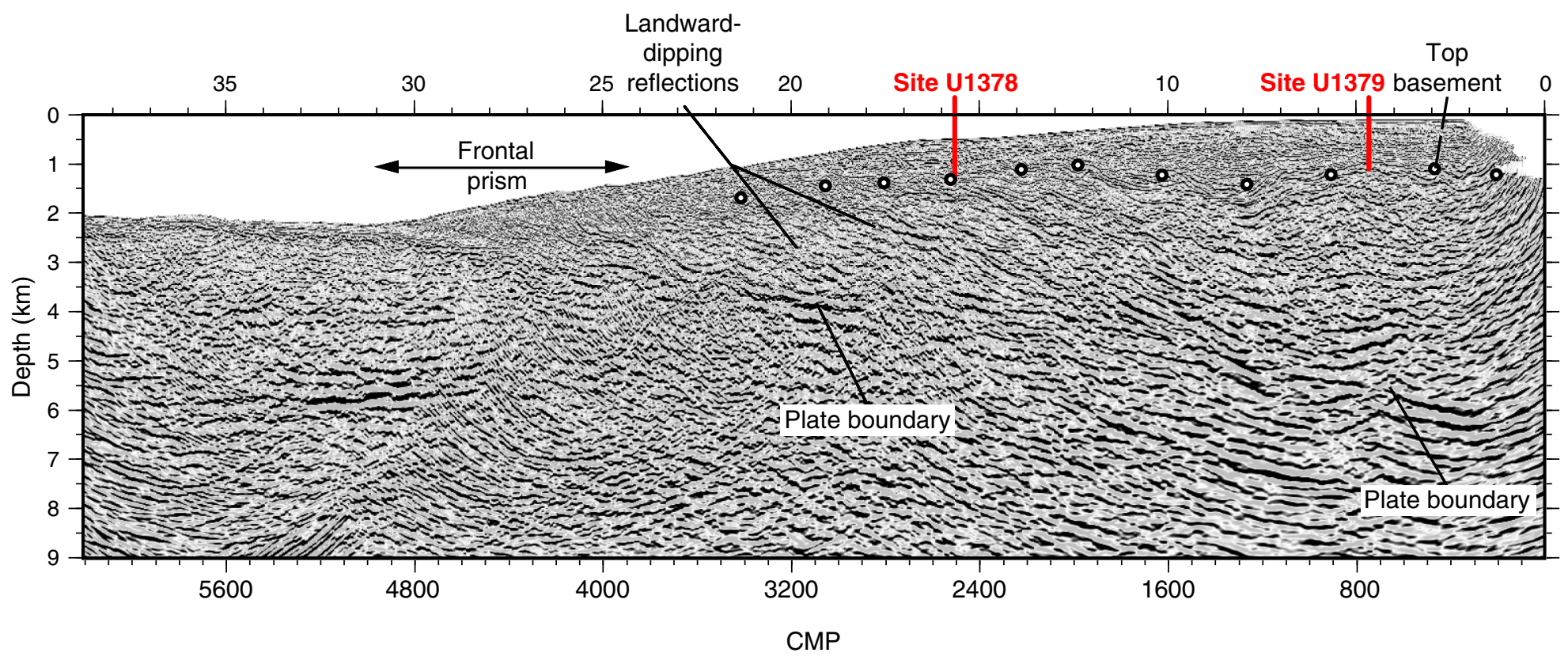


Figure F2. Detail of poststack time-migrated seismic BGR99 Line 7 centered at Site U1378. Hole drawn to target depth. $\mathrm{CMP}=$ common midpoint.

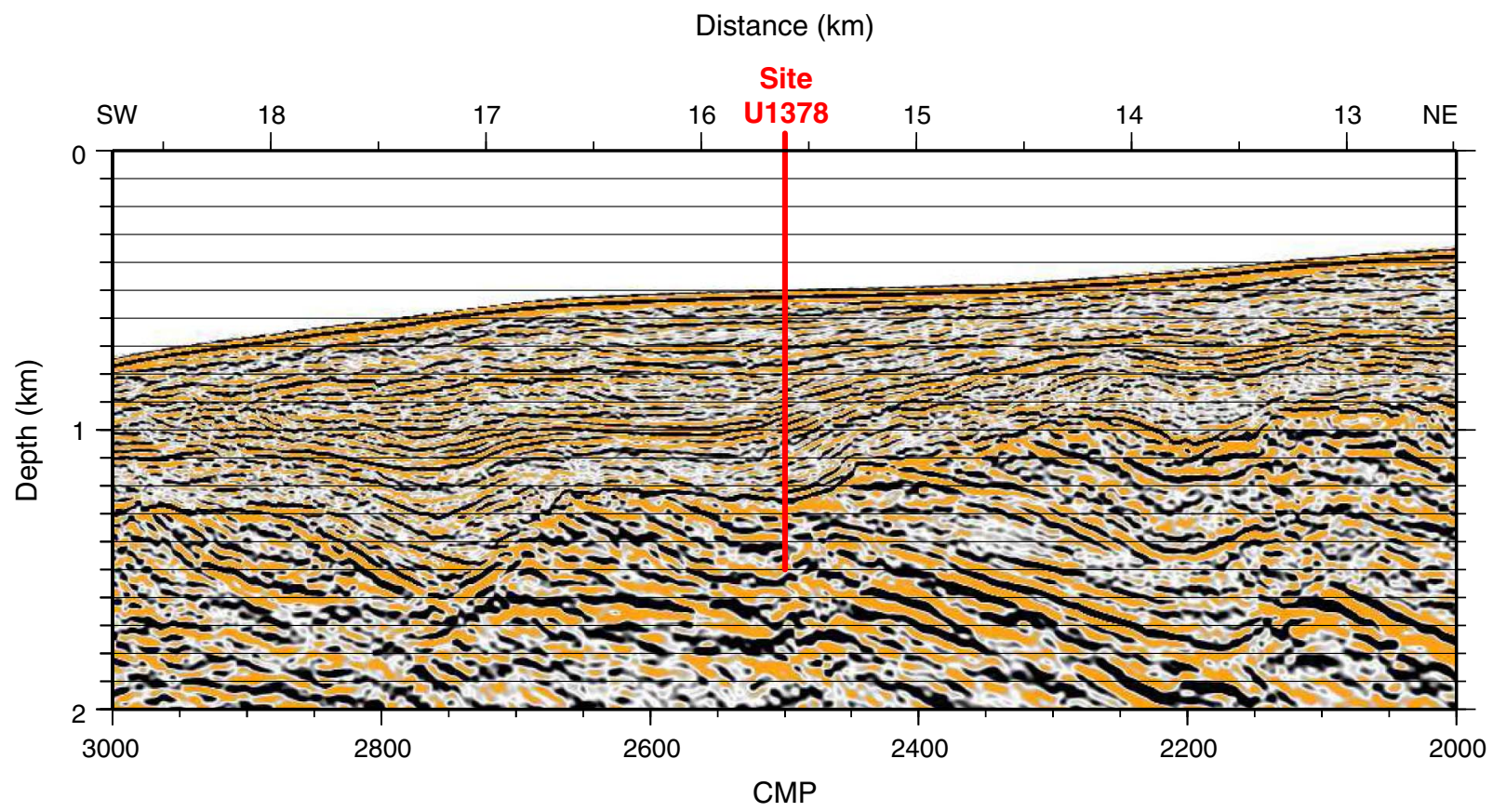


Figure F3. A. Preliminary correlation of lithostratigraphic units from Holes U1378B and U1379C (see text for unit definitions). B. Line sketch of seismic BGR99 Line 7.
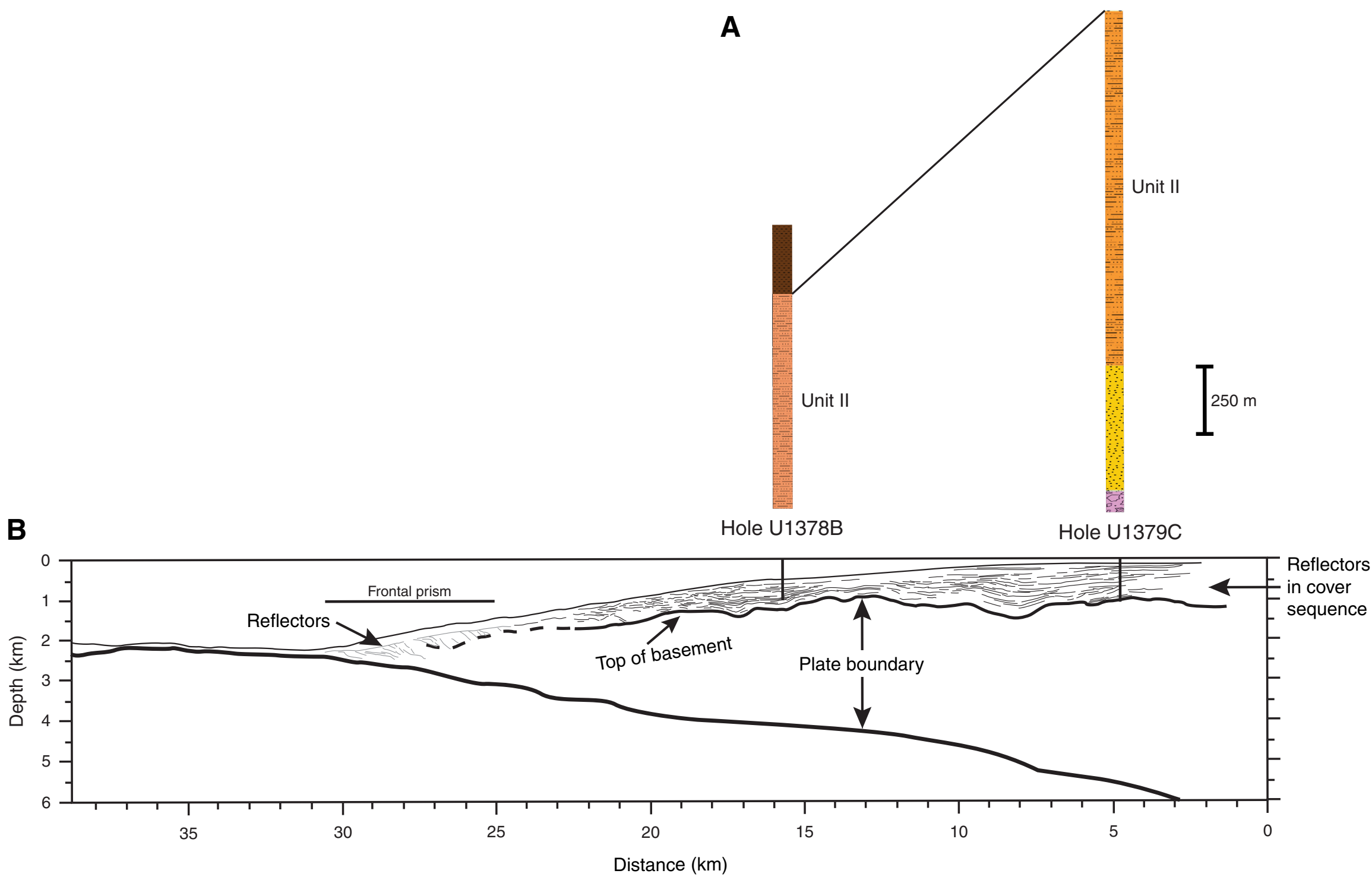
Figure F4. Graphic summary log, Hole U1378B.

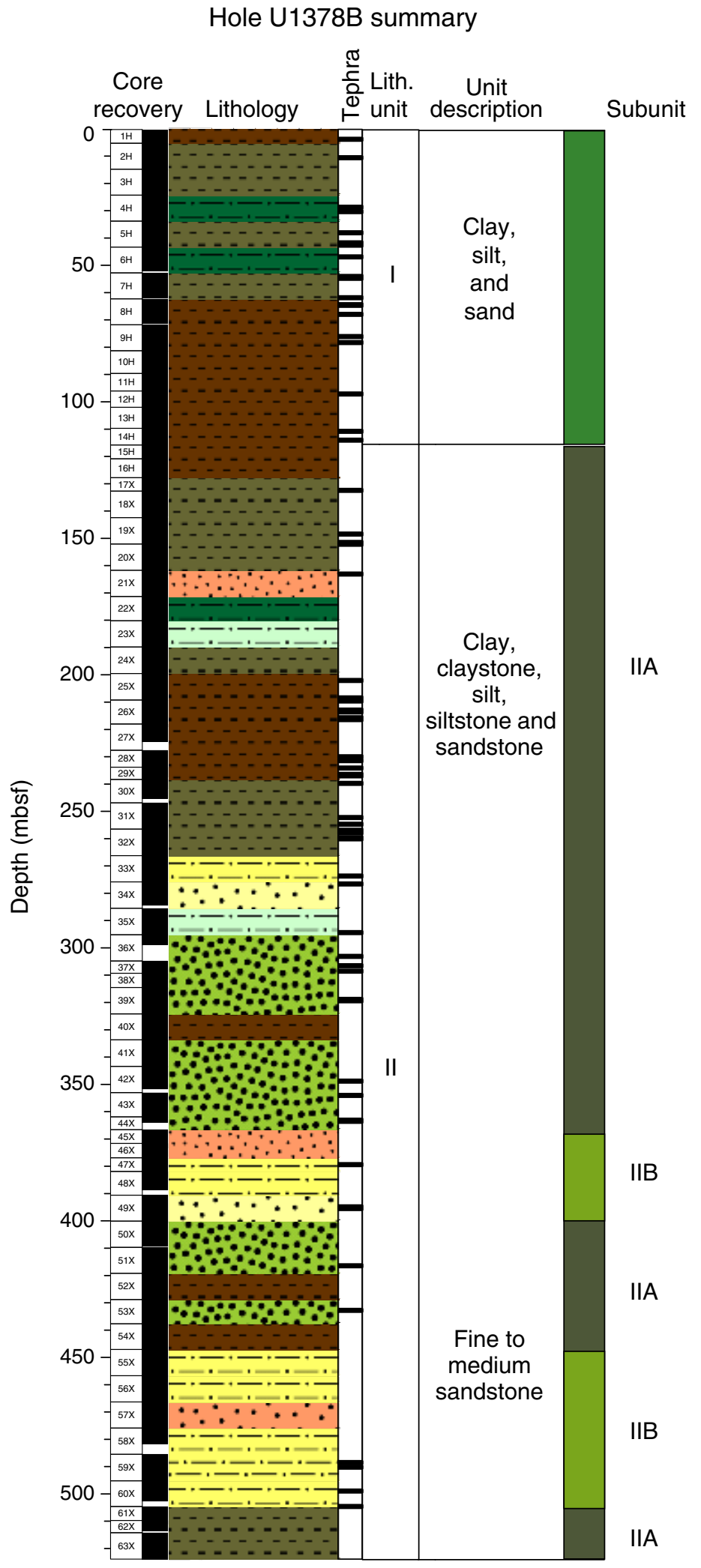


Figure F5. Representative core image of Unit I with typical olive-green silty clay and two normally graded sand intervals (interval 334-U1378B-4H-7, 10-22 cm).

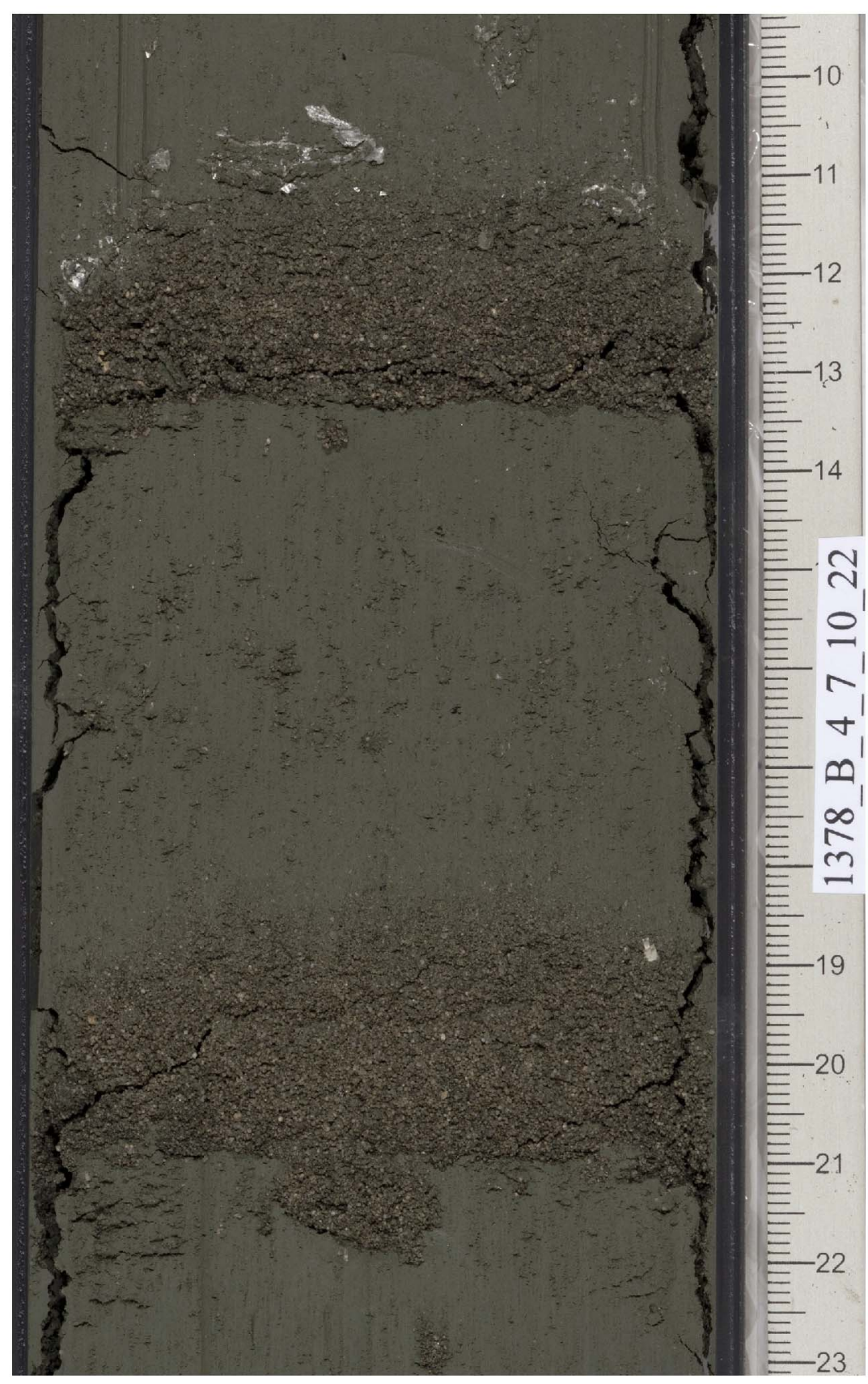


Figure F6. Representative core image of silty clay from Unit II (interval 334-U1378B-32X-5, 89-109 cm).

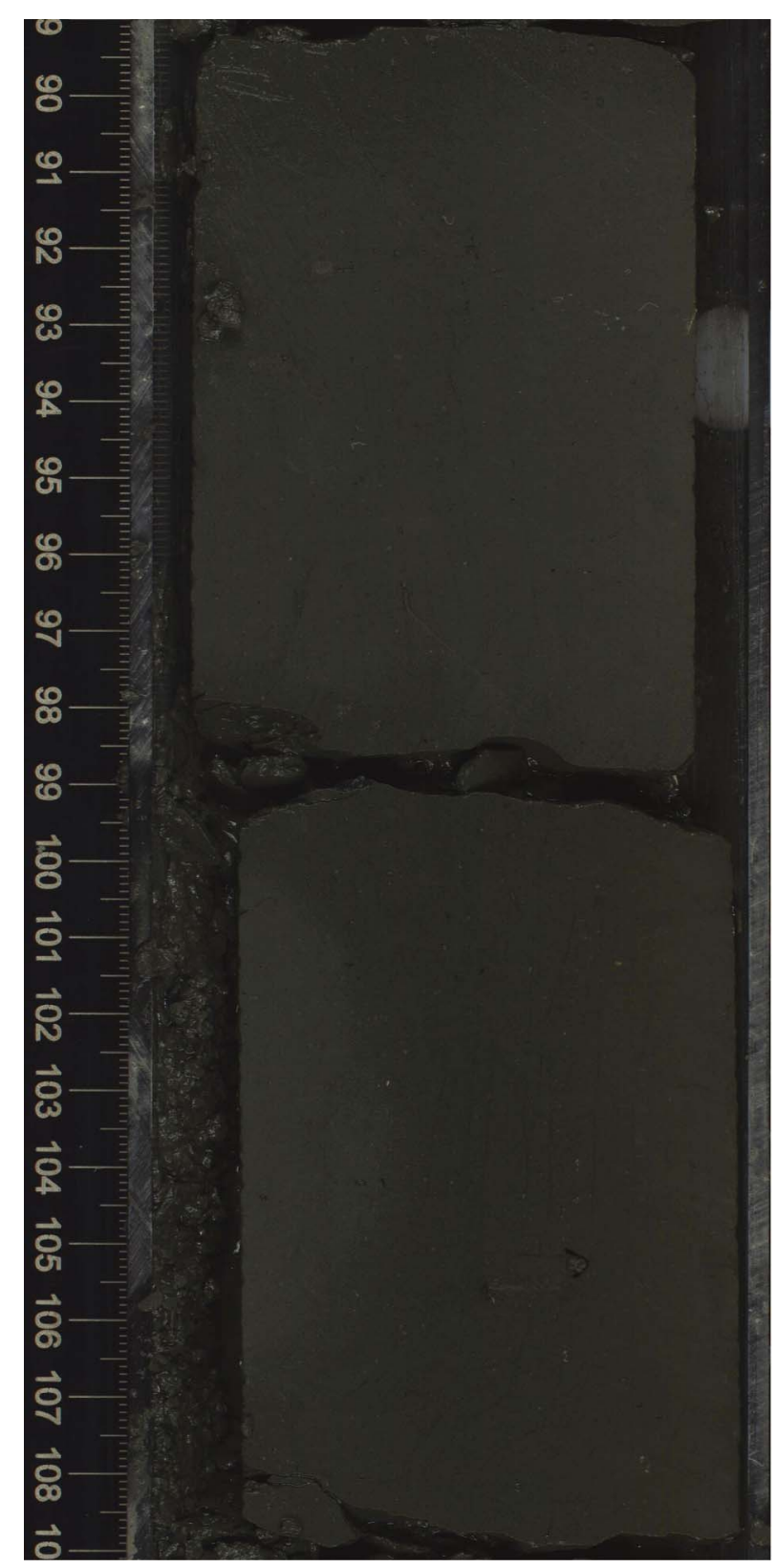


Figure F7. Core image of gray-white tephra layer with normal gradation from medium ash at the base to fine ash at the top (interval 334-U1378B-2H-5, 21-26 cm).

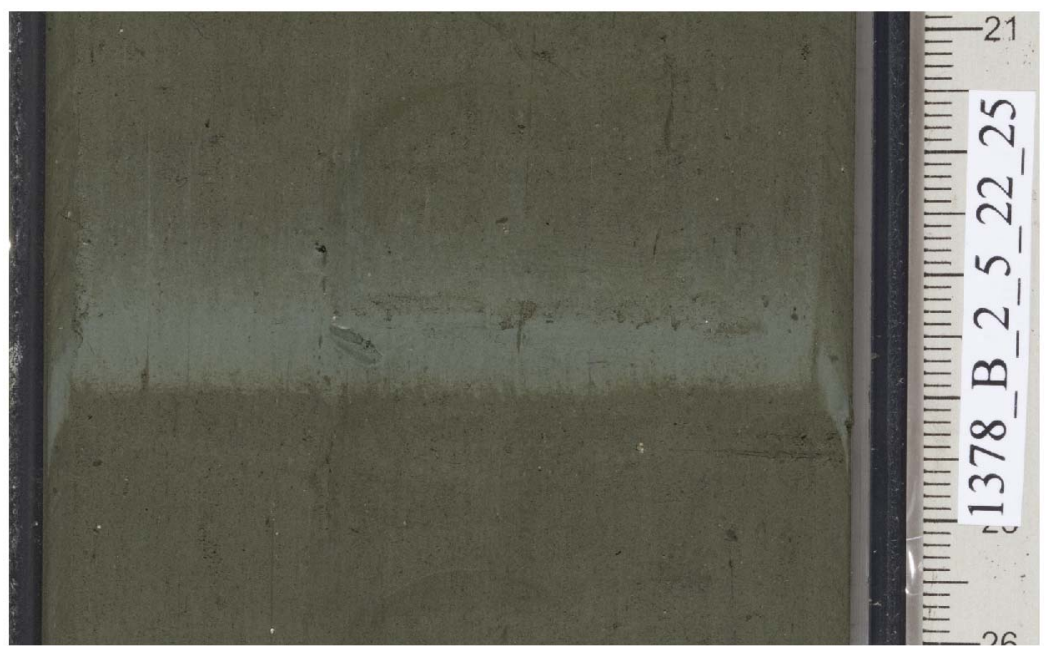


Figure F8. Representative X-ray diffractogram showing peaks consistent with quartz and anorthite in Unit I, Site U1378.

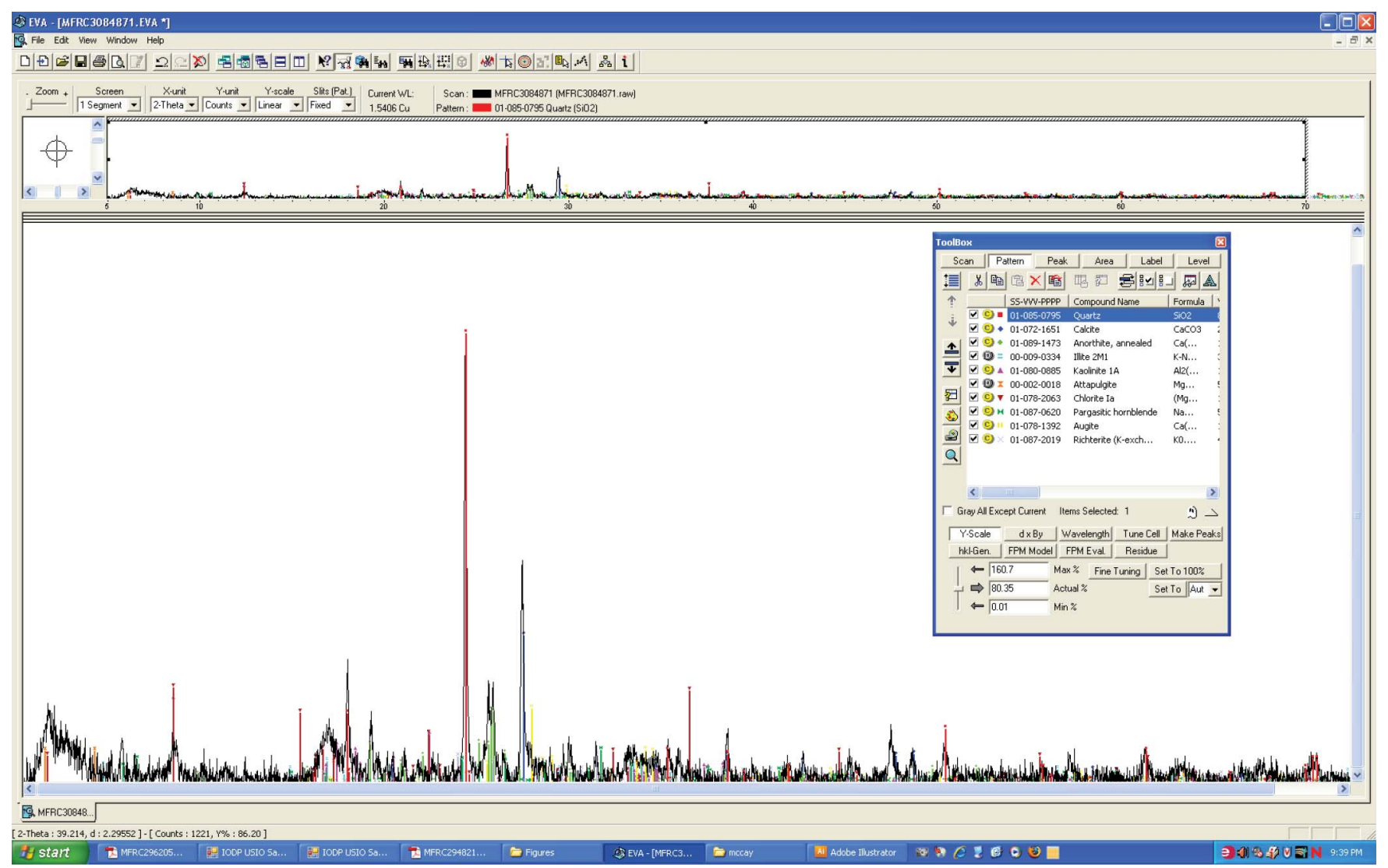


Figure F9. Late Neogene biostratigraphic zonation used for Hole U1378B. Numerical ages are based on Berggren et al. (1995) and Wade et al. (2011).

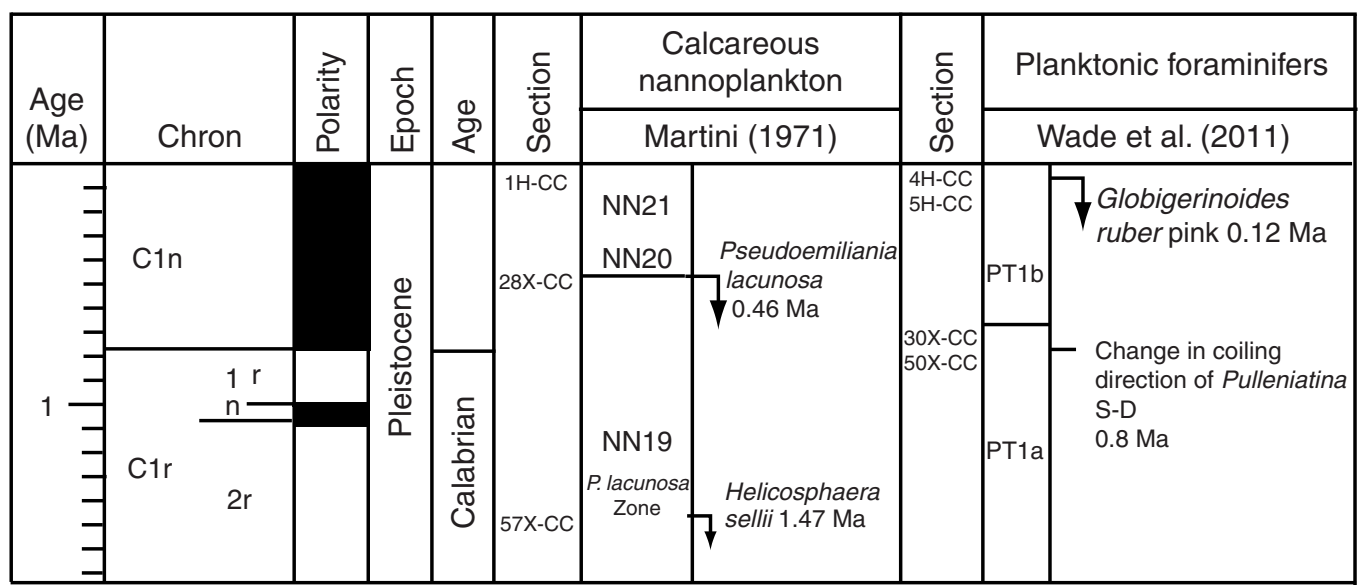


Figure F10. Age-depth plot based on first and last occurrence datums of microfossils in Hole U1378B. Approximate sediment accumulation rates (red dashed line) are based on calcareous nannofossils datums: the last occurrence (LO) of Pseudoemiliania lacunosa in Sample 28X-CC (237.47 mbsf) Core 28X-CC and the LO of Helicosphaera sellii occurs in Sample 57X-CC (476.18 mbsf). Blue dashed line indicates the estimation of planktonic foraminifer datums: the LO of Globigerinoides ruber pink in Sample 5H-CC (43.77 mbsf) and the coiling change of planktonic genus Pulleniatina from sinistral to dextral, from Sample U1378C-42X-CC (351.71 mbsf) to 30XCC (245.19 mbsf).

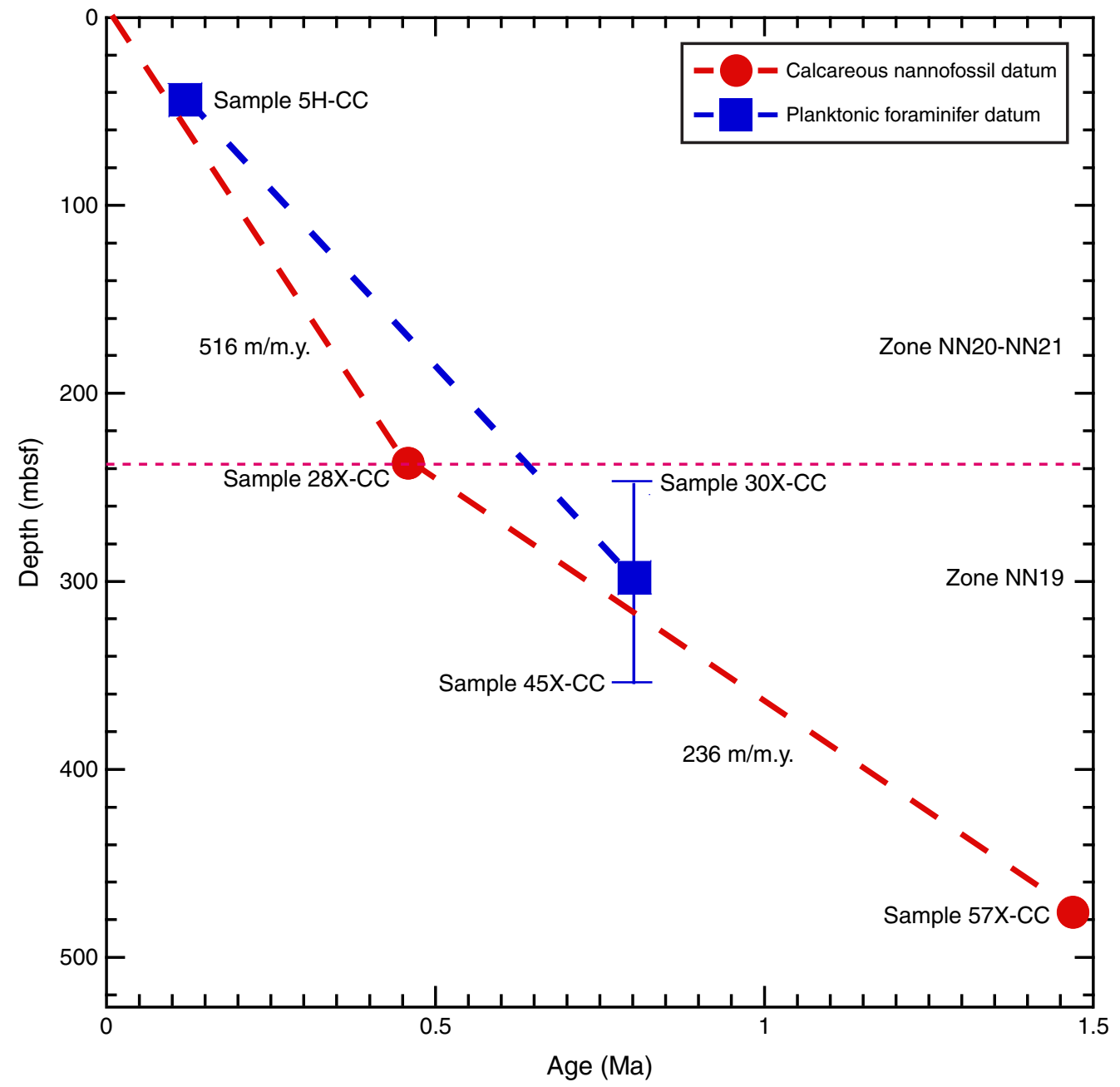


Figure F11. Plot of bedding dips, faults, and fractures as a function of depth, Site U1378. Shaded bands indicate four fault zones recognized in the slope sediments.

Bedding

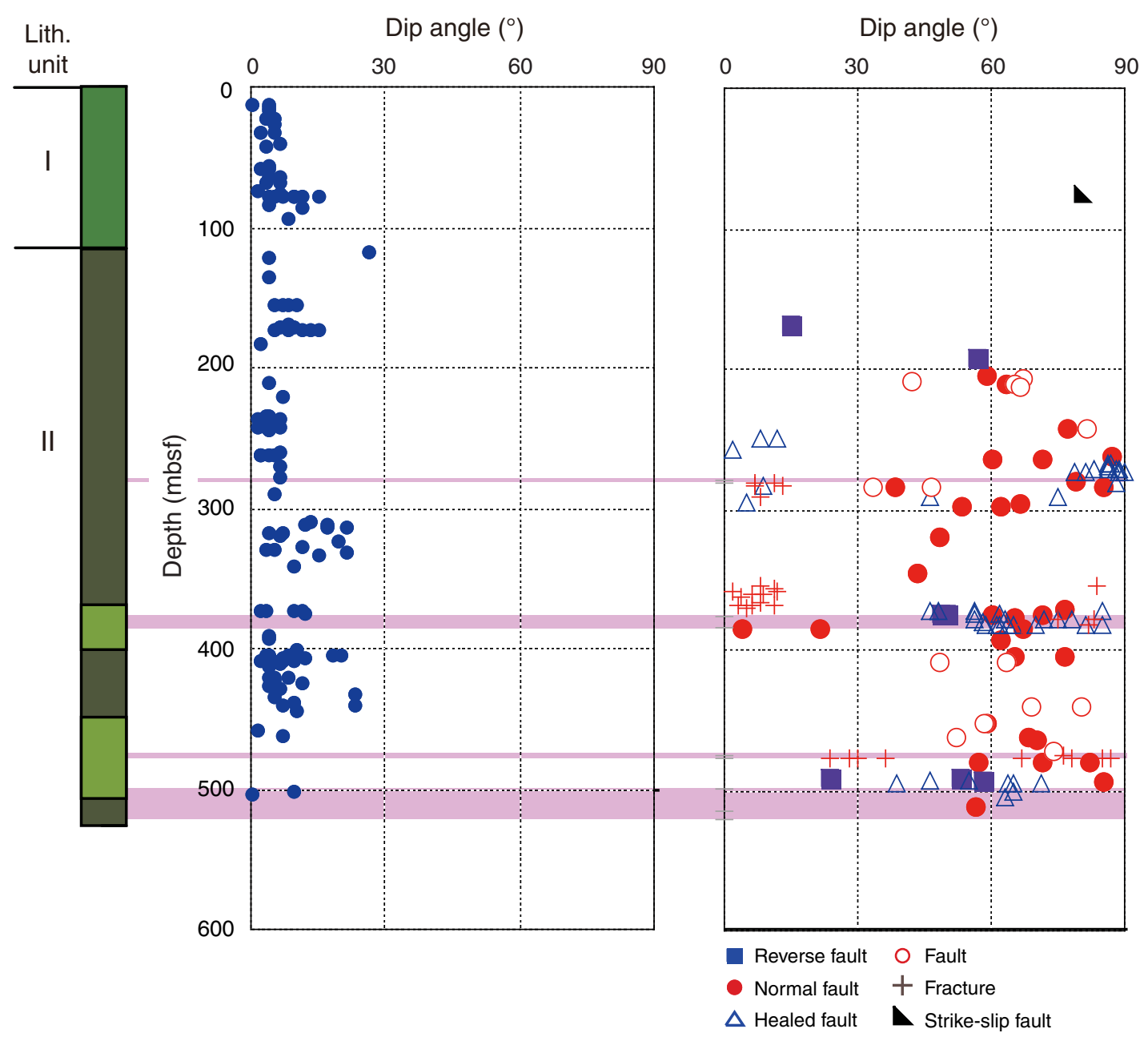


Figure F12. Lower hemisphere equal-area projection of bedding planes (great circles) after paleomagnetic corrections, Site U1378.

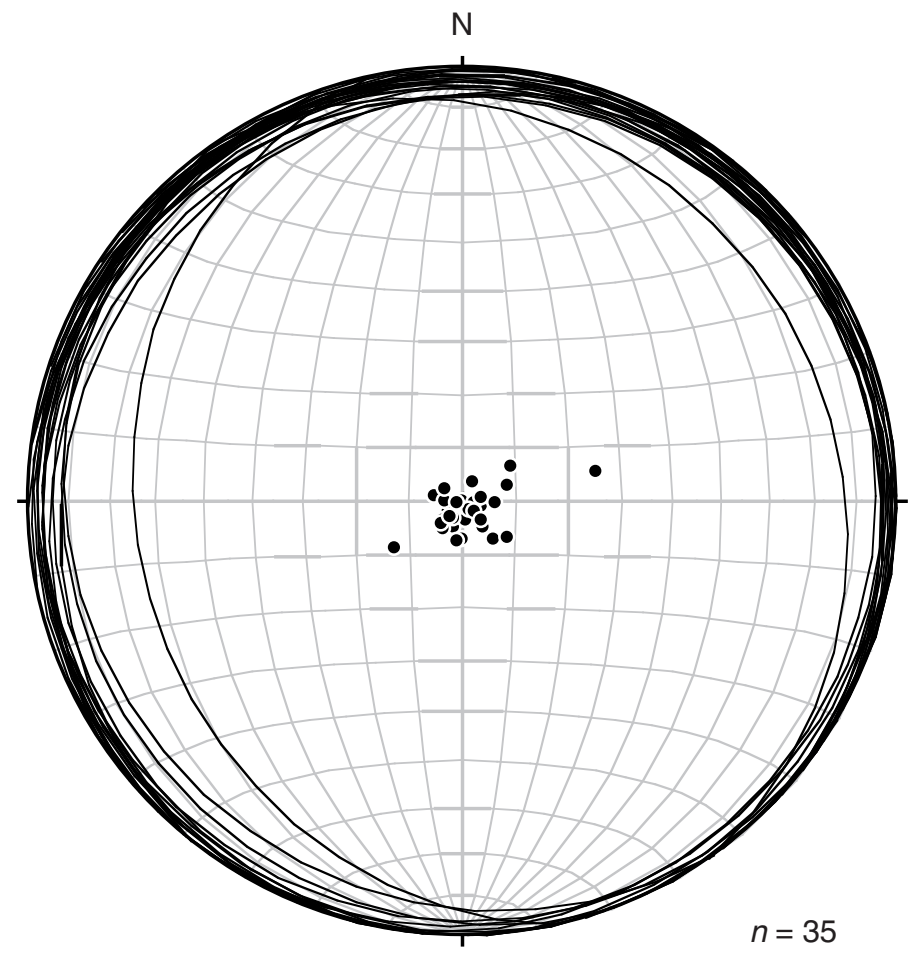


Figure F13. Lower hemisphere equal-area projections of normal faults after paleomagnetic corrections, Site U1378. Arrows indicate orientation of the slickenlines on the fault plane and movement direction of hanging wall based on the slickenlines on the fault plane.

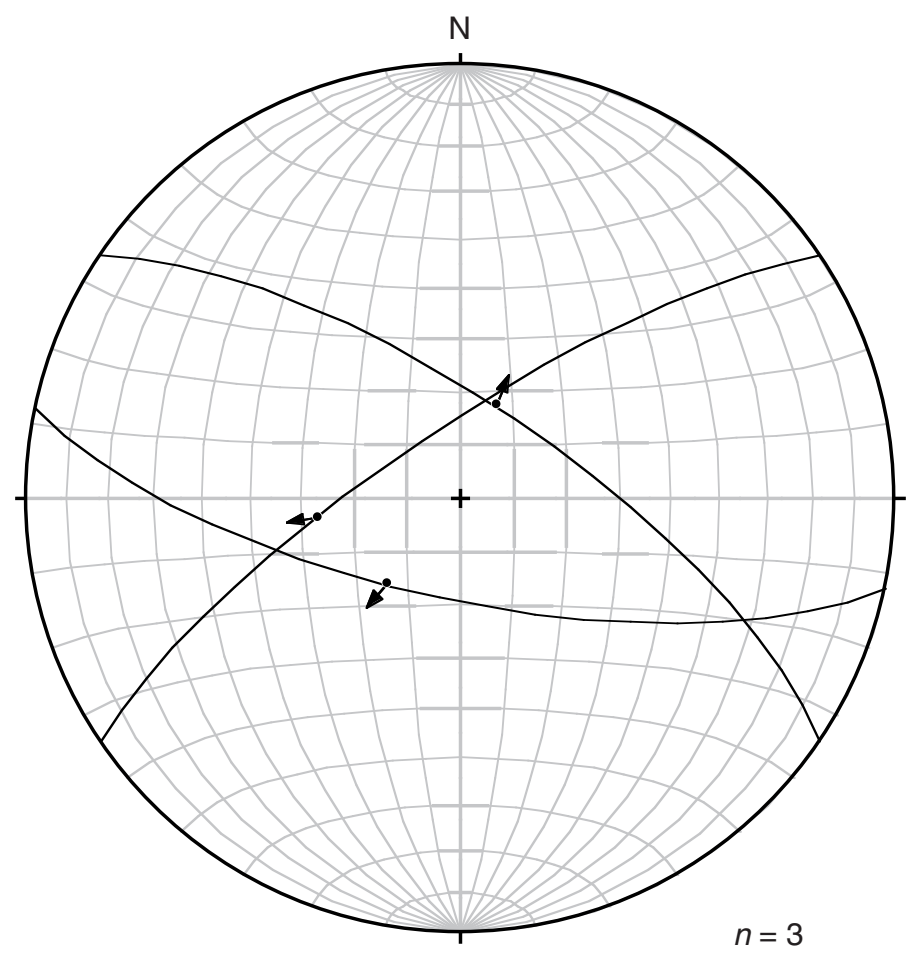


Figure F14. Plot of vein array dips as a function of depth, Site U1378. Shaded bands indicate four fault zones recognized in the slope sediments.

Array of sediment-filled veins

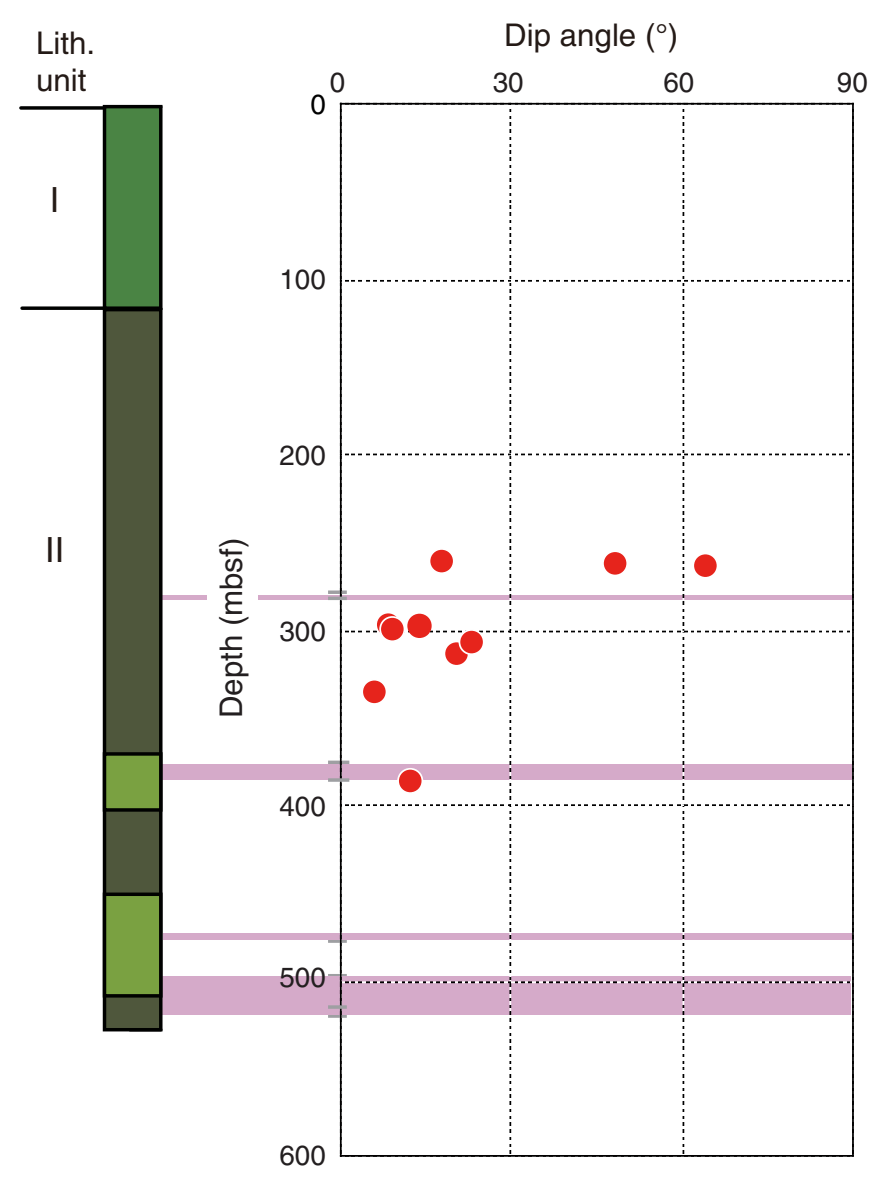


Figure F15. Core image and sketch of sediment-filled veins identified at 280 mbsf, Hole U1378B.

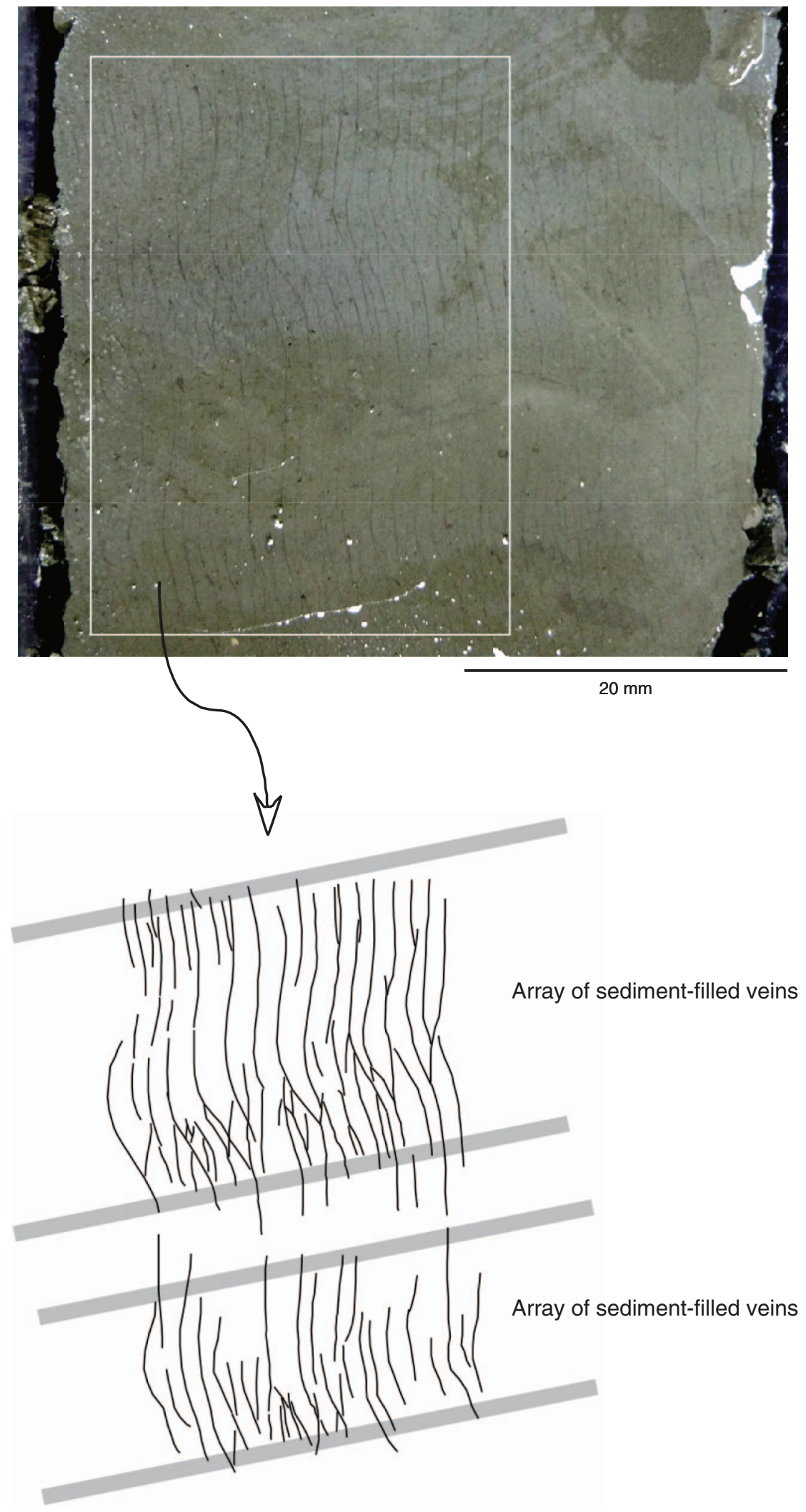


Figure F16. Core images of fractured and brecciated zones in the fault zone between 375 and 380 mbsf, Hole U1378B. Note the dominant fragment size $(<1 \mathrm{~cm})$ within the brecciated zone and the large fragments within the fractured zone.
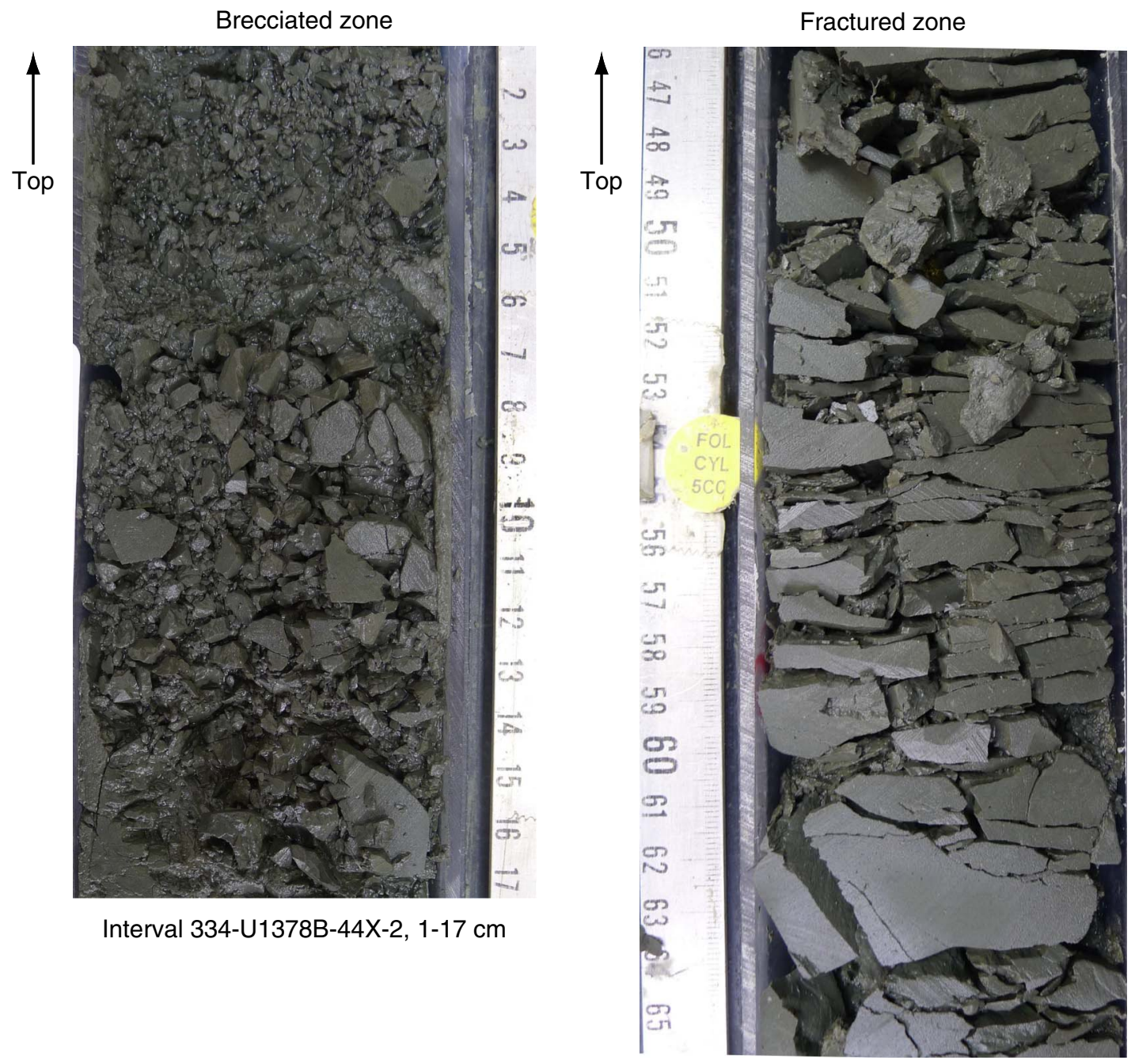

Interval 334-U1378B-43X-7, 46-66 cm 
Figure F17. Concentration-depth profiles of sulfate, alkalinity, ammonium, methane, calcium, and magnesium for the upper 50 mbsf, Site U1378.
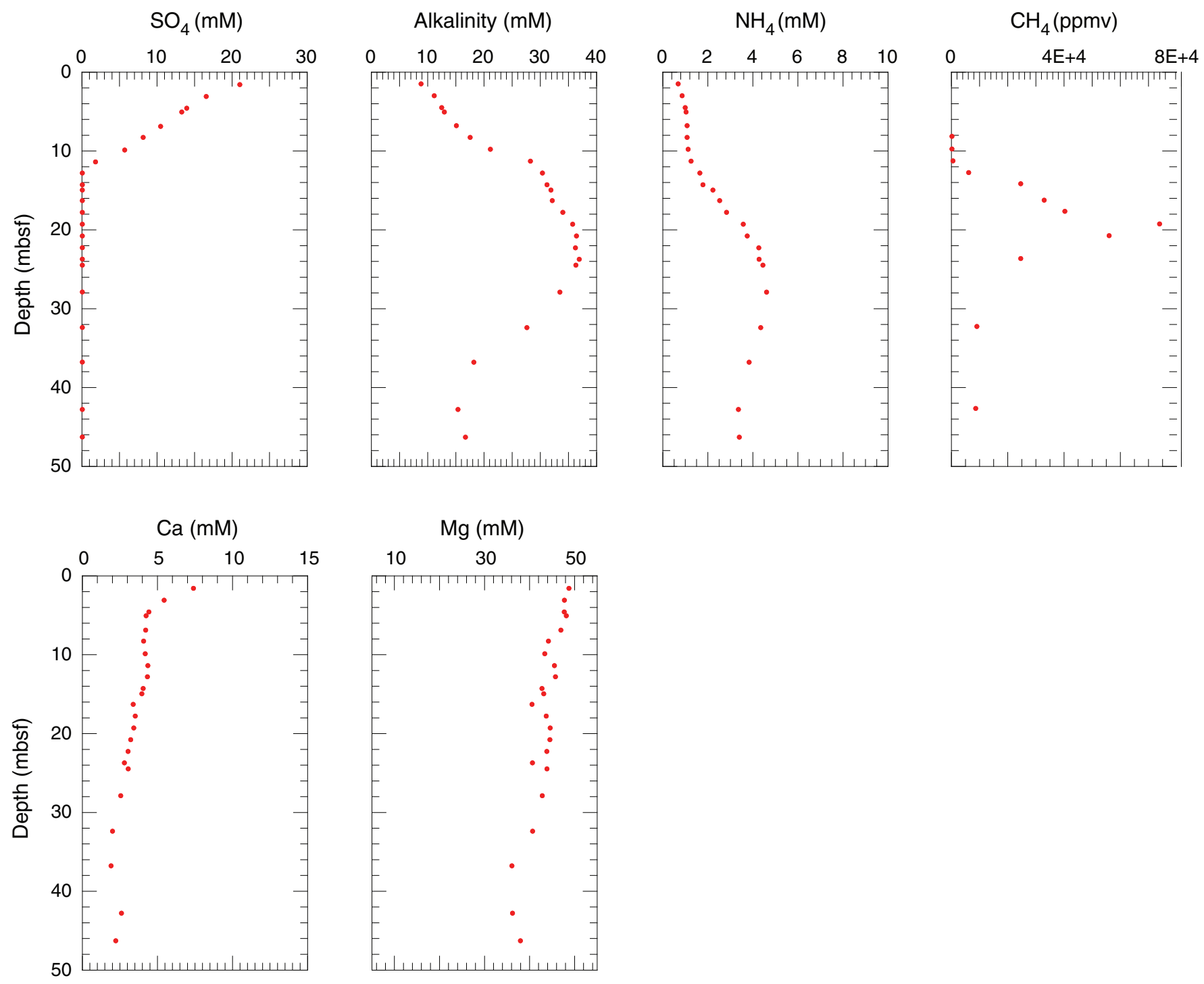
Figure F18. Concentration-depth profiles, of salinity, chlorinity, calcium, magnesium, sodium, potassium, alkalinity, and ammonium, Site U1378.
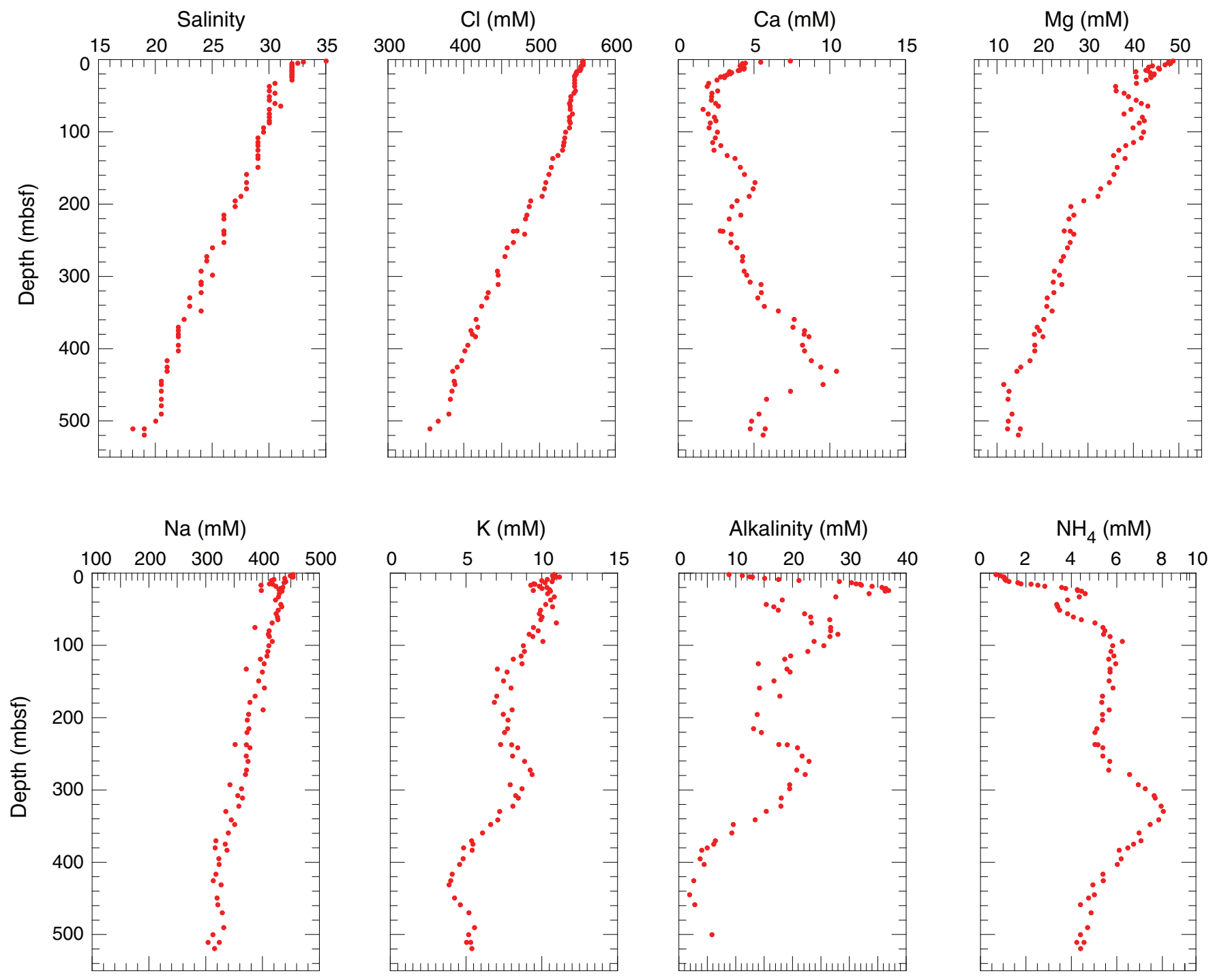


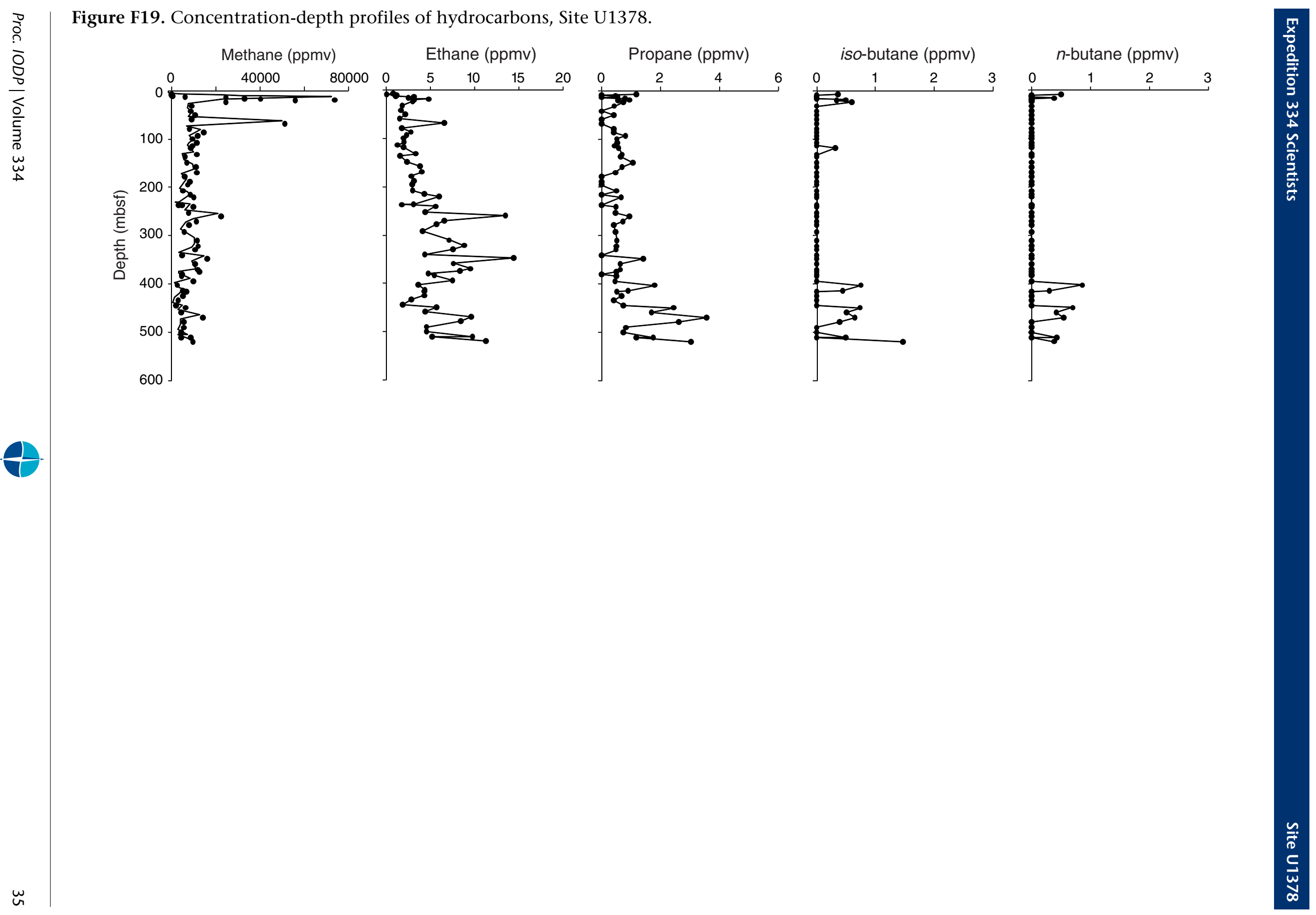


Figure F20. Depth profile of $\mathrm{CH}_{4} /\left(\mathrm{C}_{2} \mathrm{H}_{6}+\mathrm{C}_{3} \mathrm{H}_{8}\right)$ ratio, Site U1378.

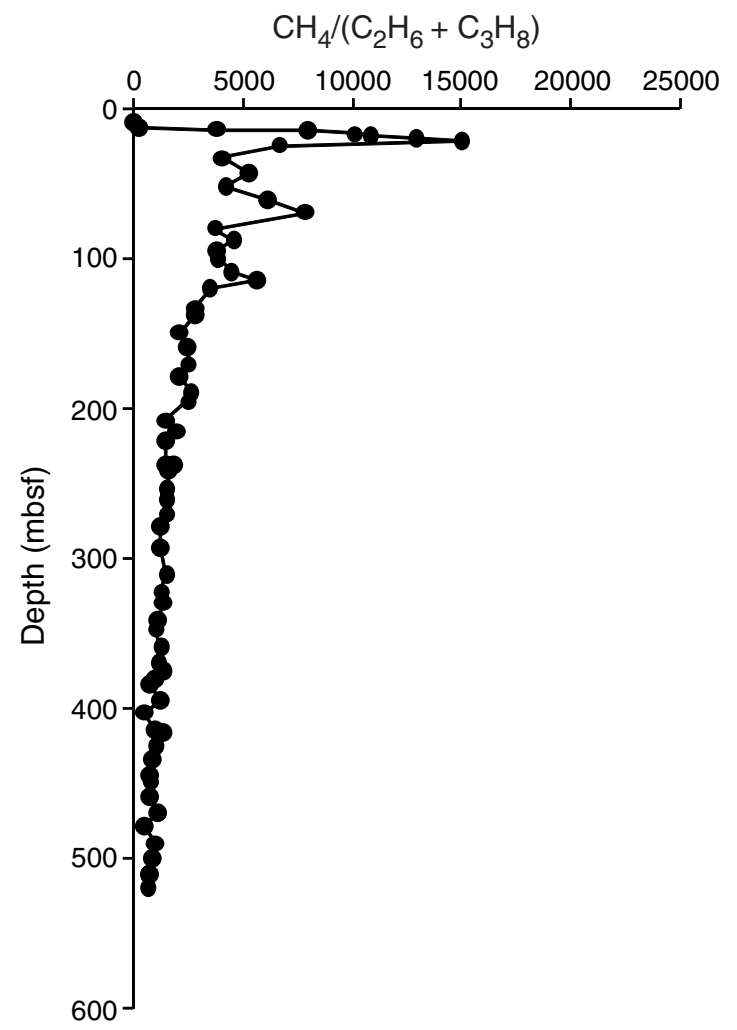




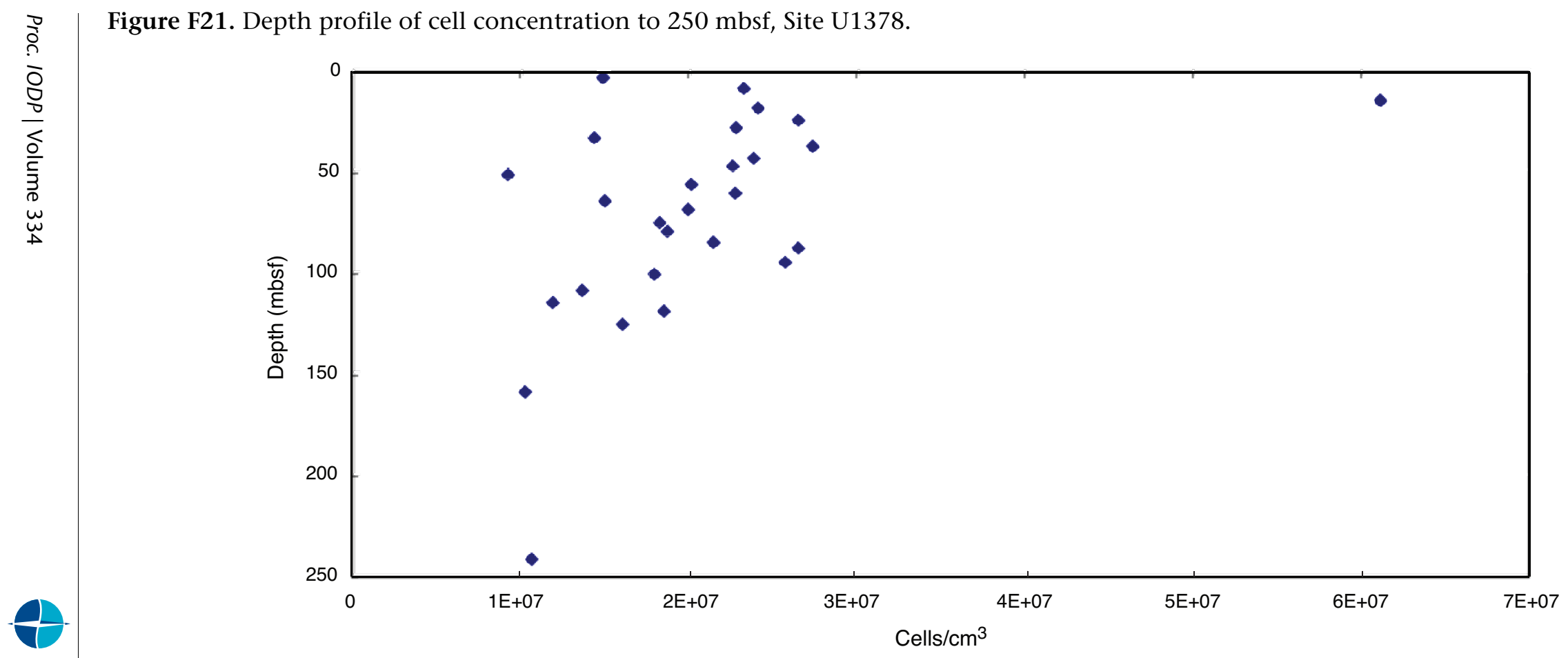




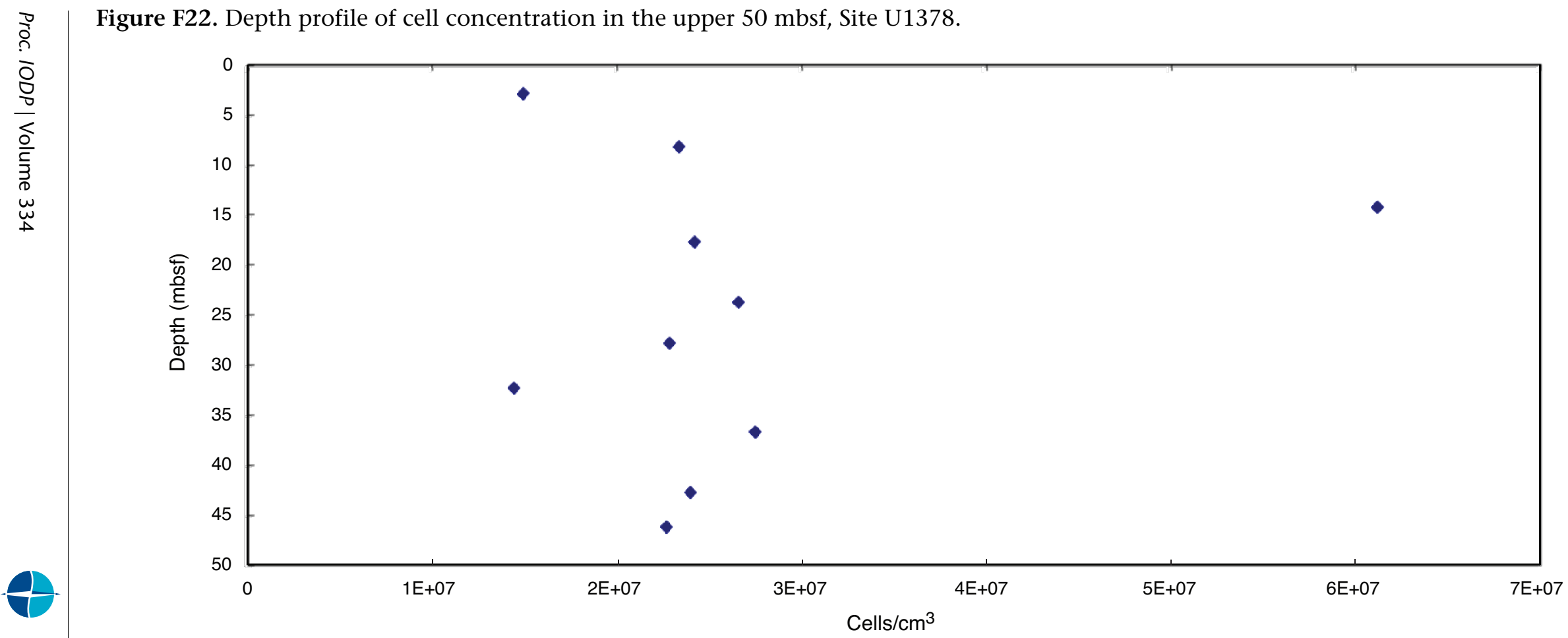


Figure F23. Plots of combined results of density and porosity measurements, Hole U1378B. A. GRA density measured on the WRMSL (black circles) and wet bulk density measured on discrete samples using MAD Method C (red circles). B. Grain density measured on discrete samples using MAD Method C. C. Porosity determined using MAD Method C.

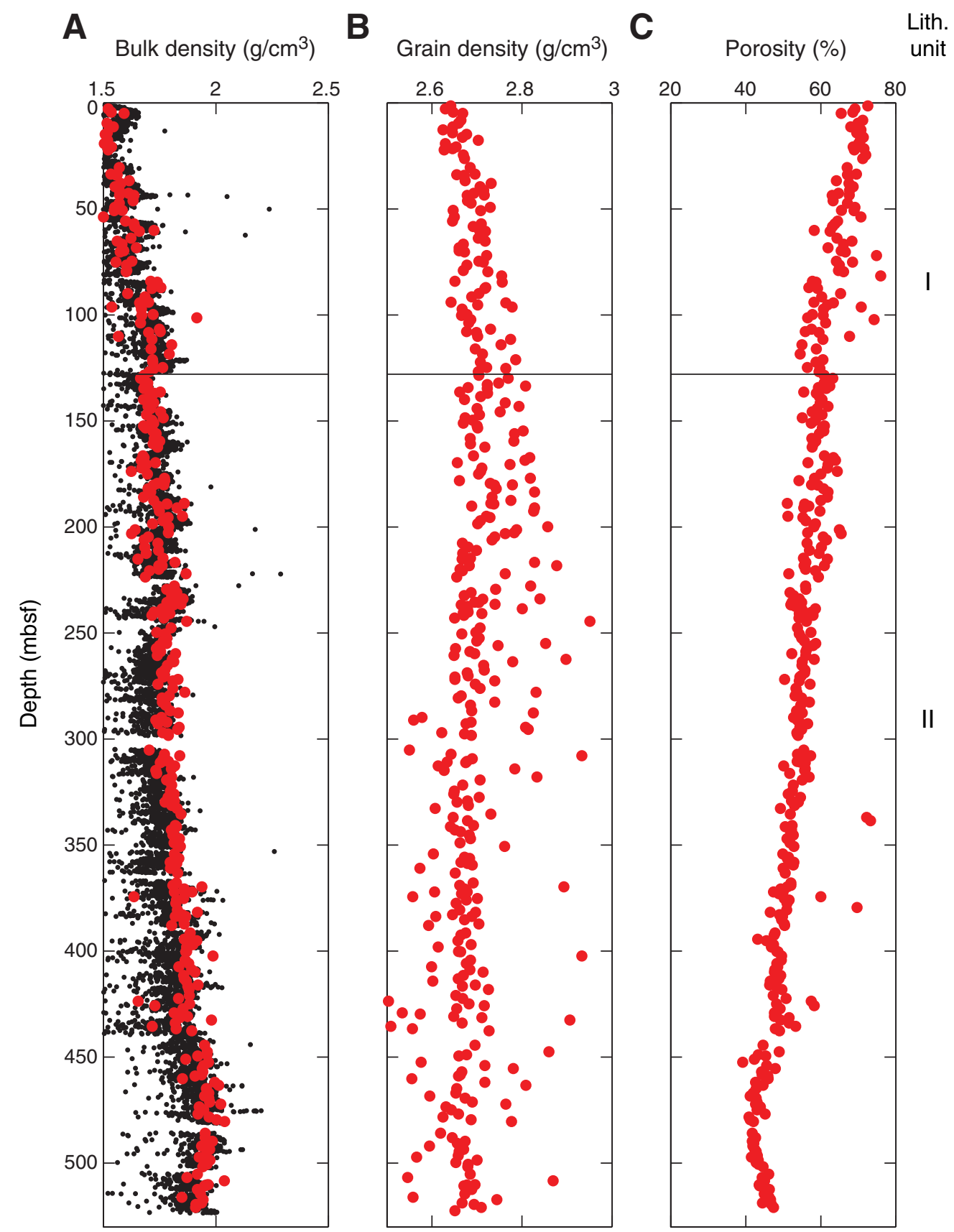


Figure F24. A, B. Plots of magnetic susceptibility as a function of depth, Hole U1378B. Volumetric magnetic susceptibility measurements were made on the Whole-Round Multisensor Logger, and point measurements were made on the Section Half Multisensor Logger.

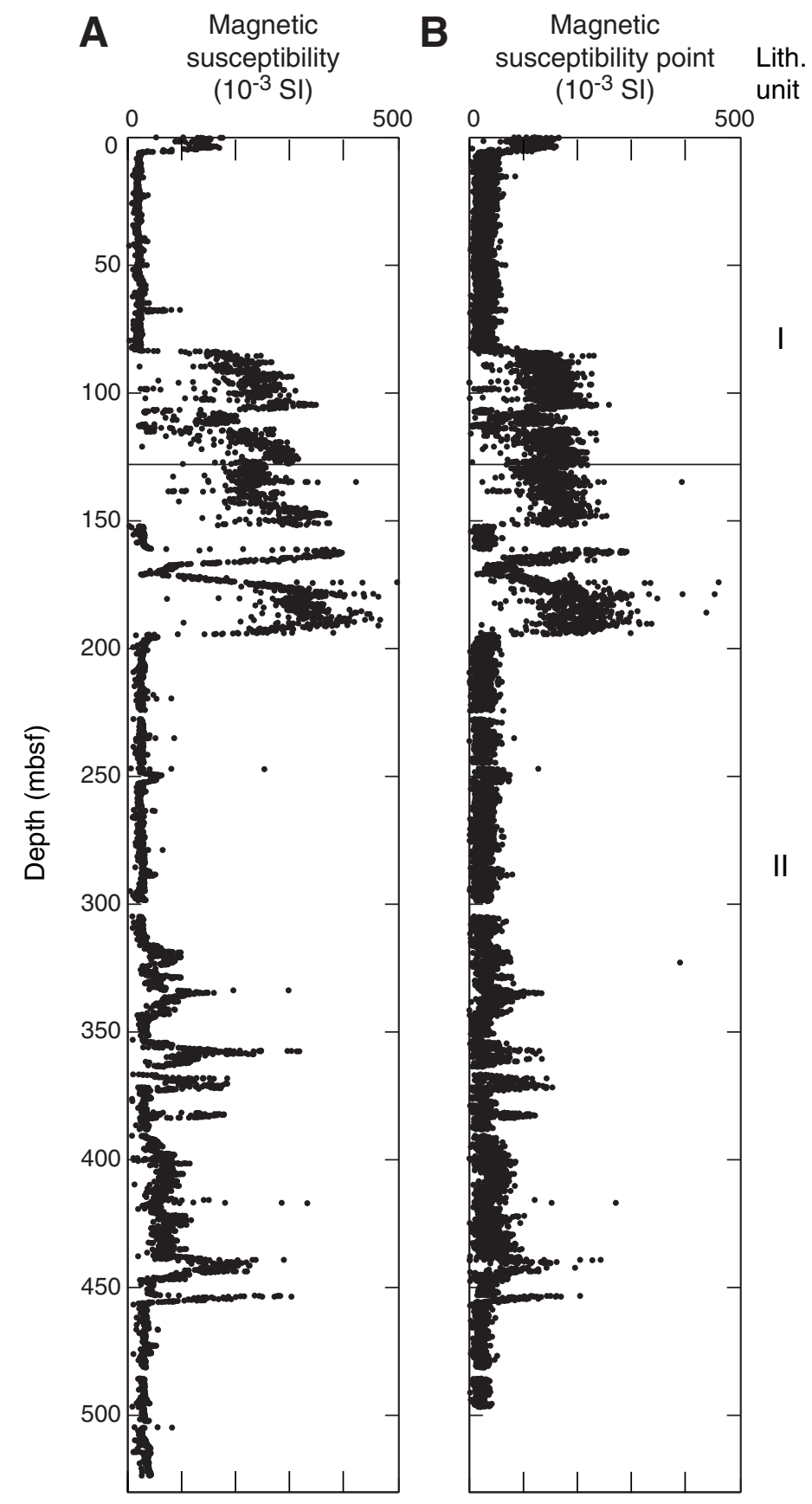


Figure F25. Plot of natural gamma radiation (NGR) as a function of depth, Hole U1378B.

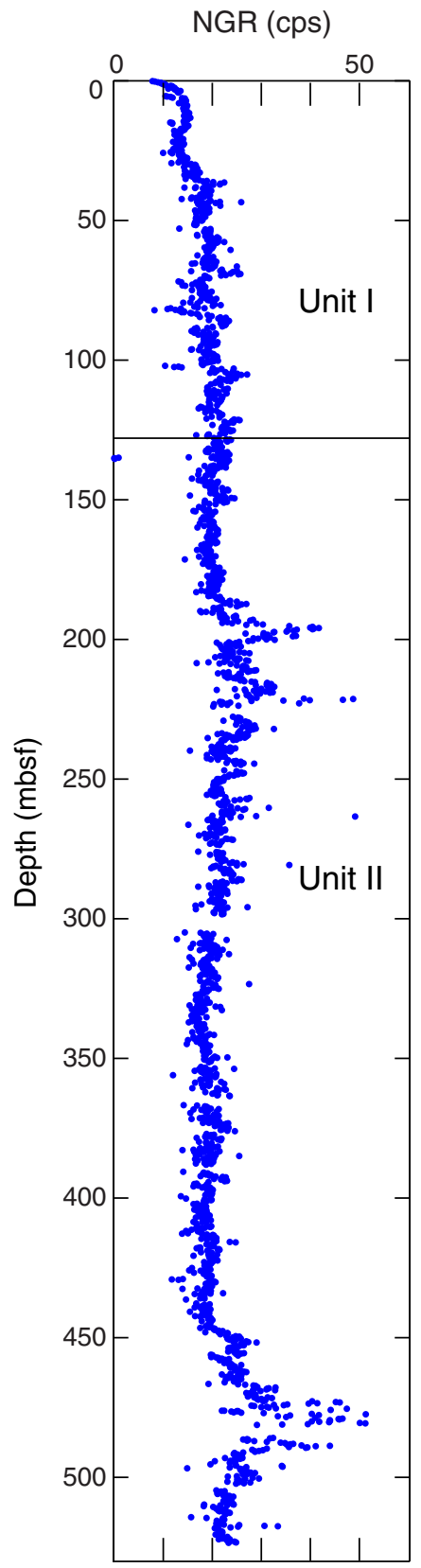


Figure F26. Plot of compressional wave velocity, Hole U1378B. $P$-wave velocity was measured on discrete samples using the Section Half Measurement Gantry. WRMSL = Whole-Round Multisensor Logger.

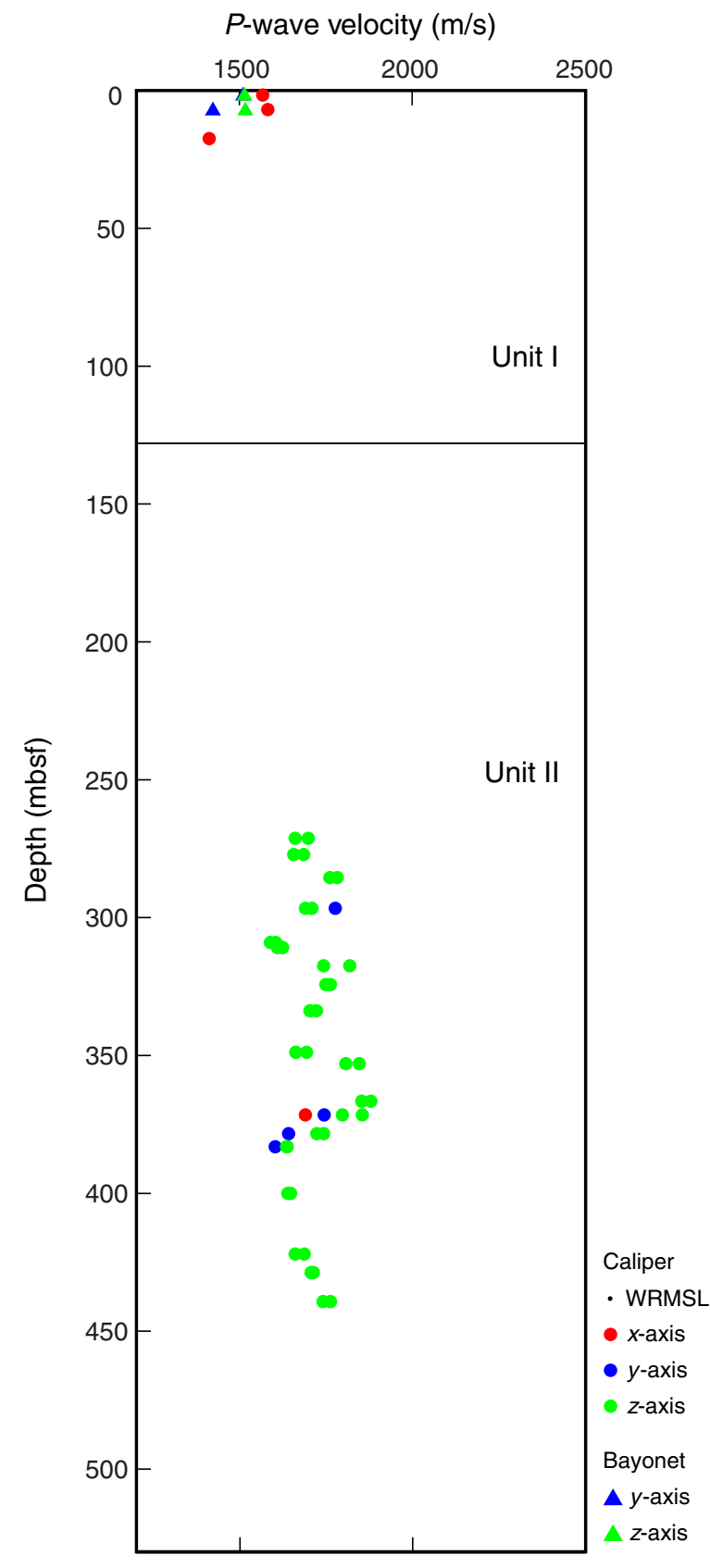


Figure F27. Plots of thermal data, Hole U1378B. A. Thermal conductivity values as a function of depth. Blue = needle-probe measurements, red = half-space measurements. B. Equilibrium temperatures. Estimated temperature (line) based on linear fit to thermal conductivity and thermal gradient.

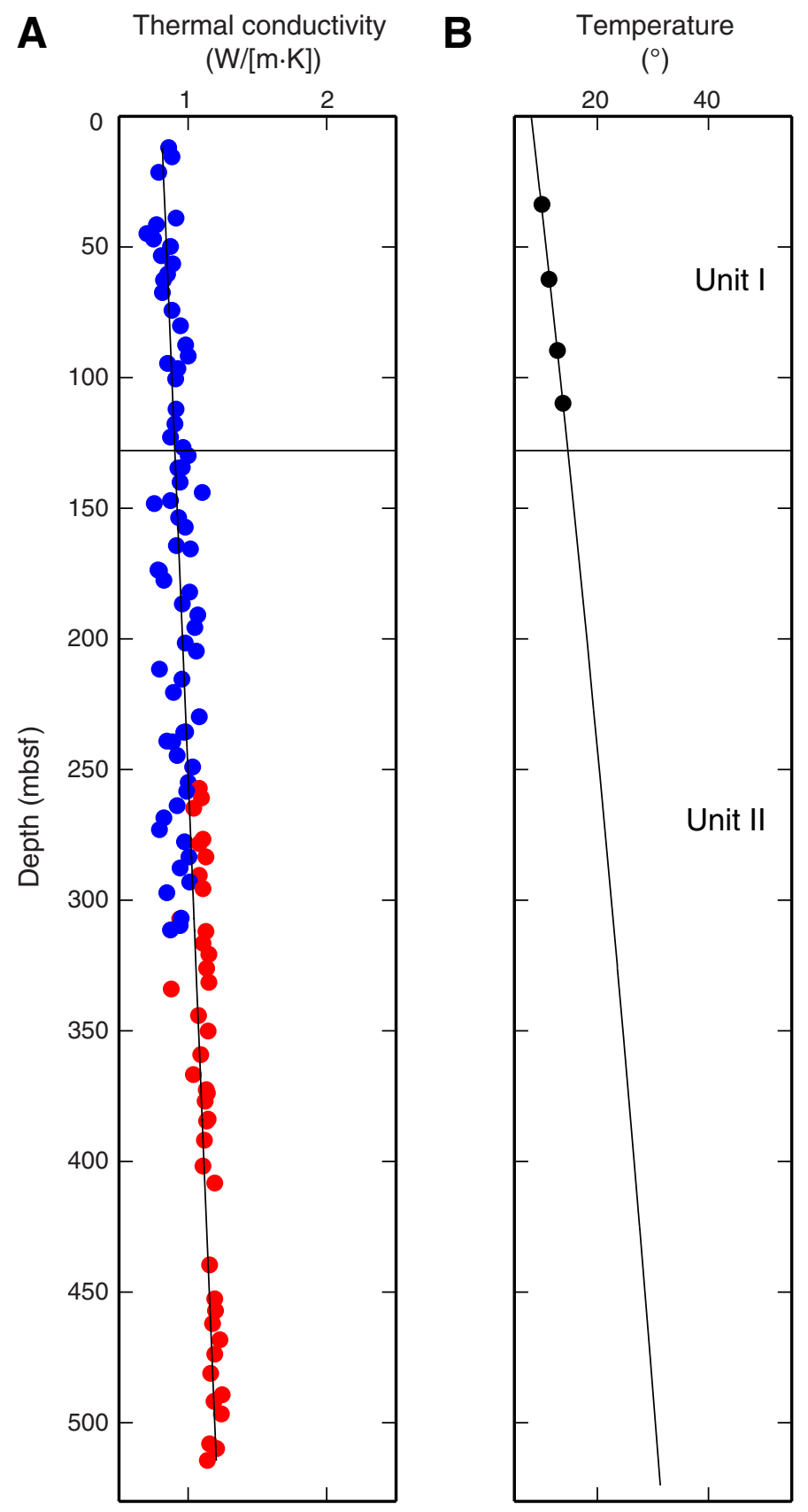


Figure 28. Plots of temperature-time series measured during deployment of the advanced piston corer temperature tool (APCT-3) at Site U1378. Unshaded area indicates data used for equilibrium temperature fit. Triangle indicates beginning of fit and inverted triangle indicates end of fit.

Time after penetration (s)
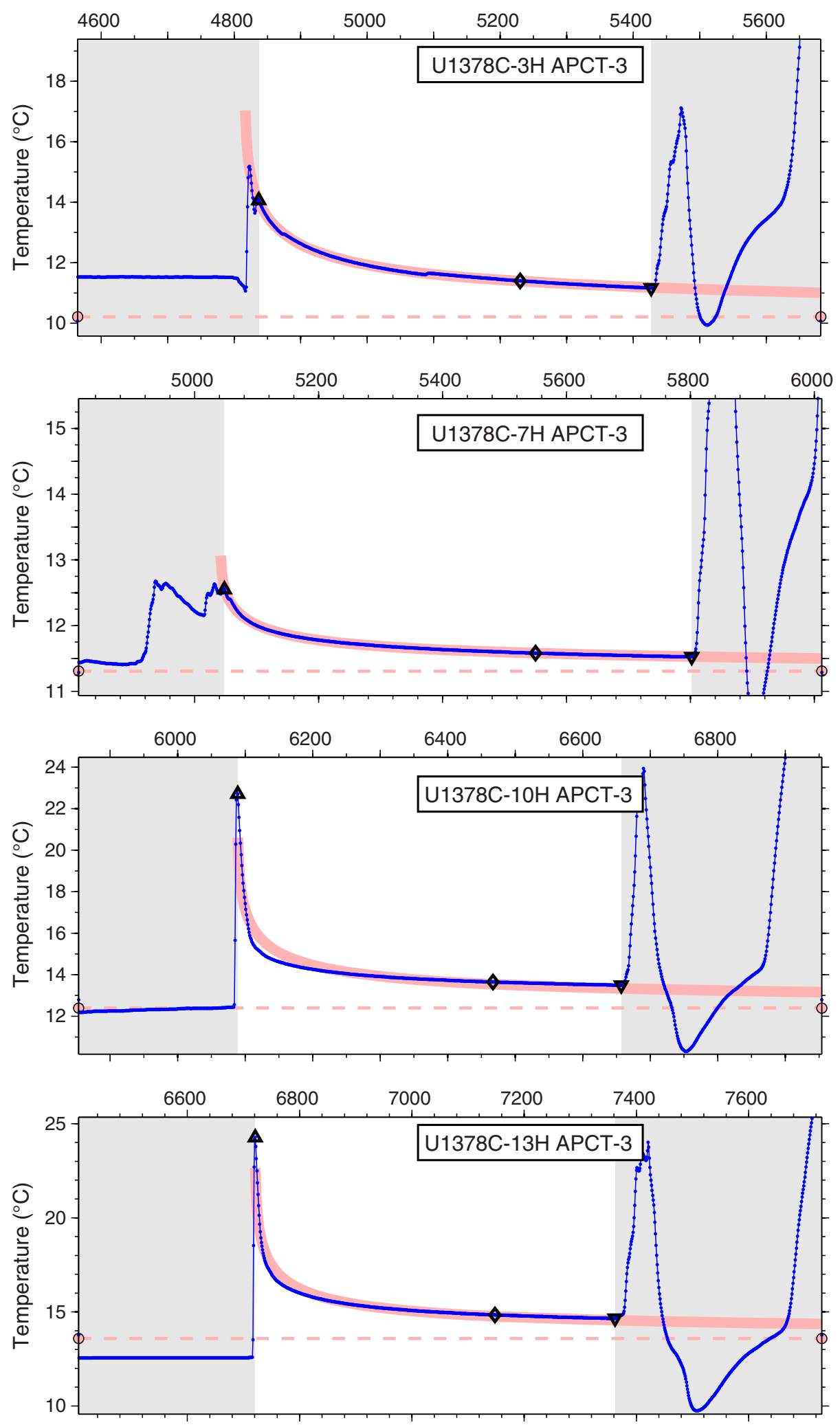
Figure F29. Plot of undrained shear strength measured using an automated vane shear device, Hole U1378B.

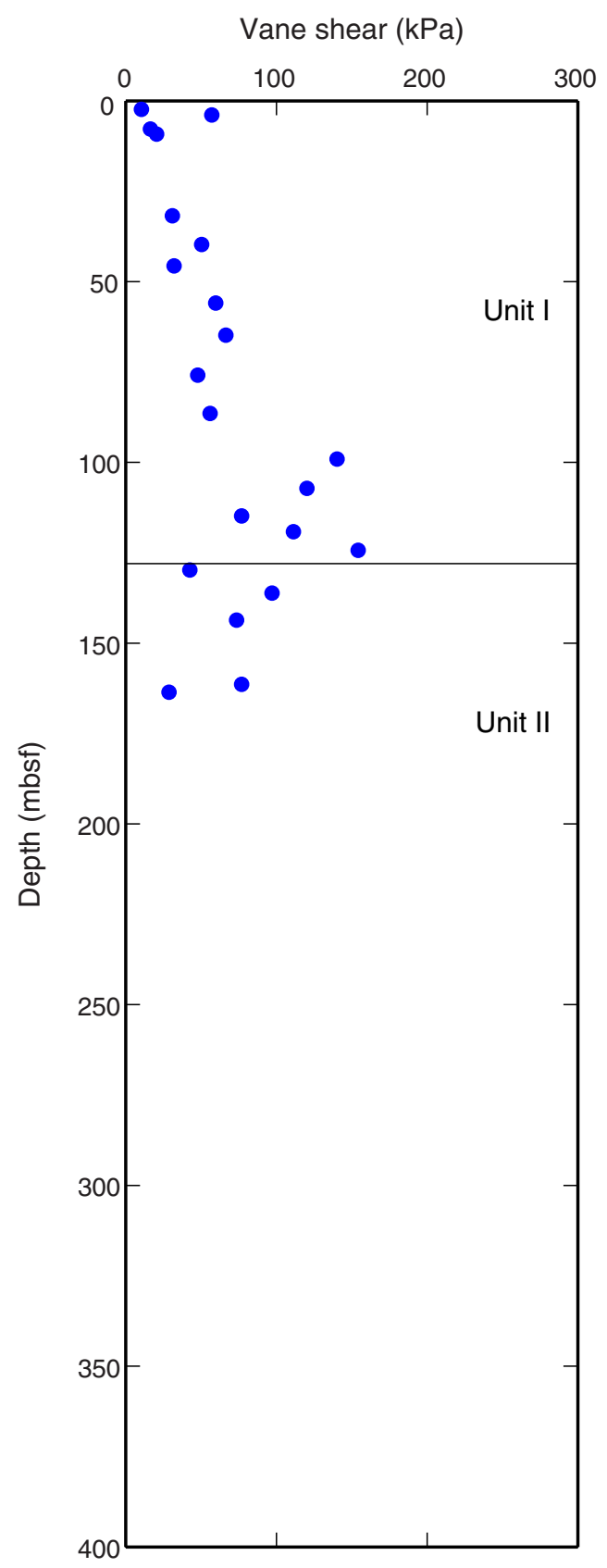


Figure F30. $\mathrm{L}^{*}, \mathrm{a}^{*}$, and $\mathrm{b}^{*}$ reflectance values vs. depth, Hole U1378B.

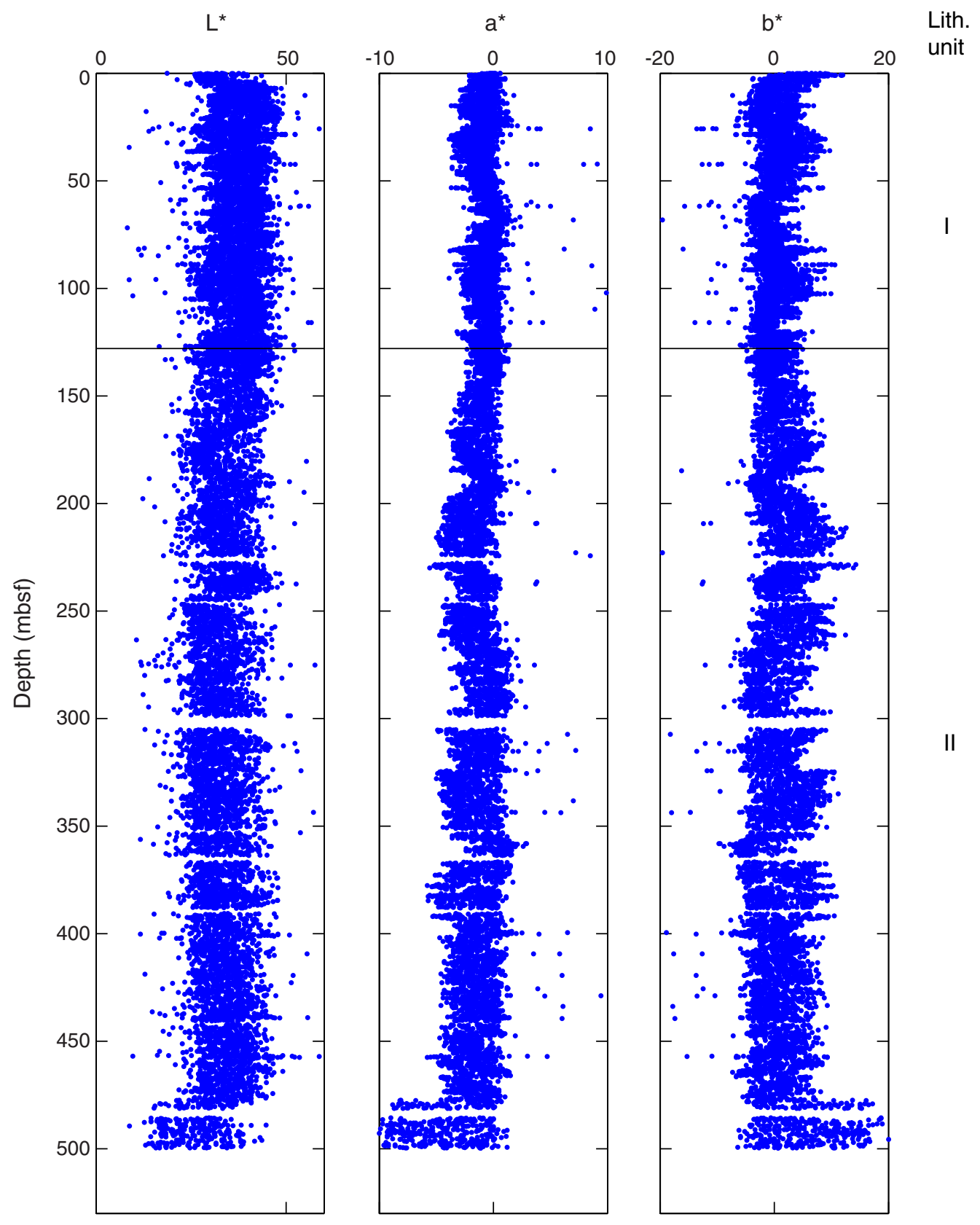


Figure F31. Plots of paleomagnetic measurements on archive sections of (A) natural remanent magnetization and (B) after $15 \mathrm{mT}$ AF demagnetization, Hole U1378B. Red stars indicate characteristic remanent magnetization of discrete samples.
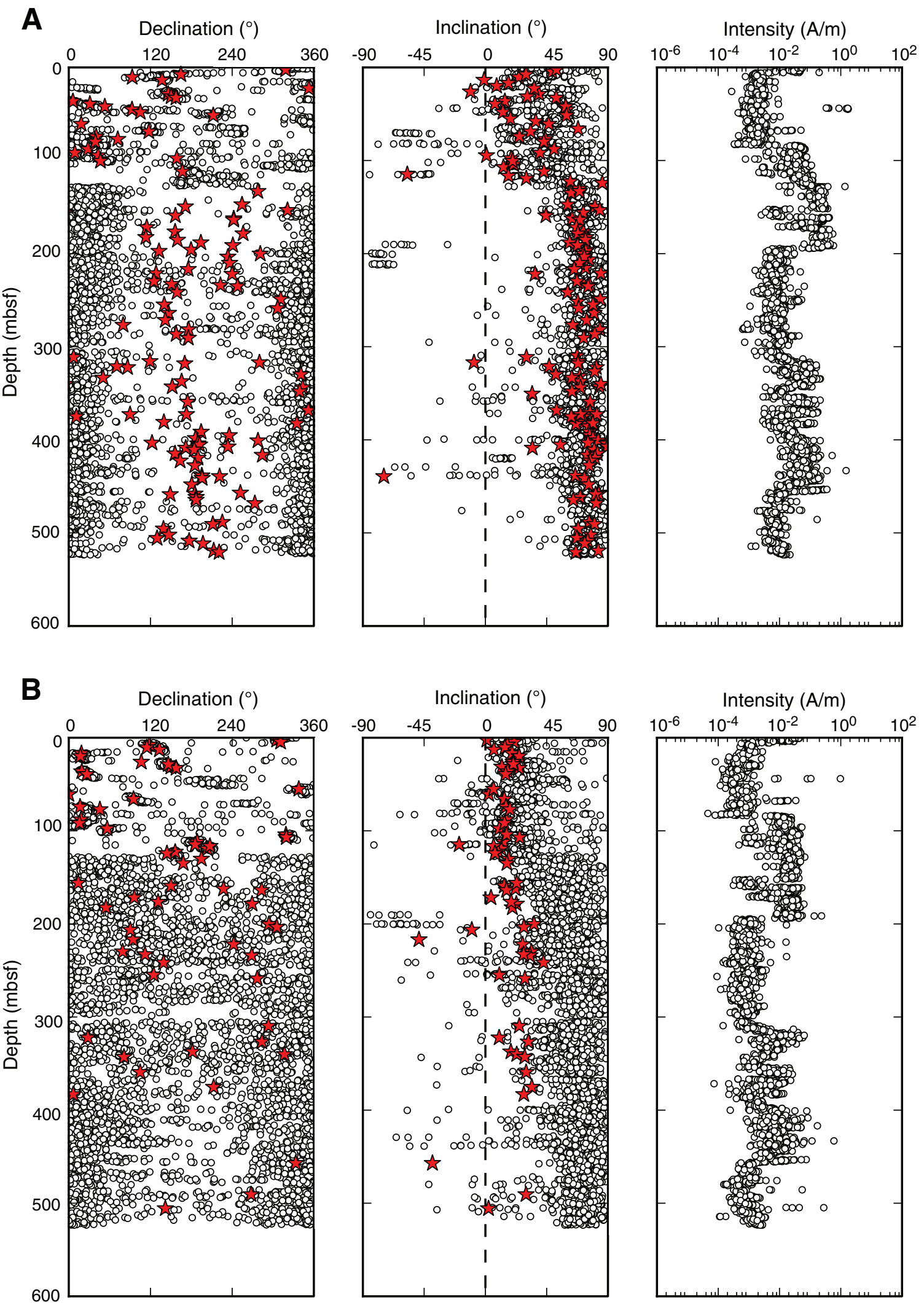
Figure F32. Representative vector endpoint diagrams (Zijderveld, 1967) of magnetization directions through stepwise AF demagnetization for (A, B) samples from APC cores, showing the steep downward component of magnetization imparted by the coring process is easily removed by AF demagnetization, (C) sample from an XCB core with well-defined characteristic remanent magnetization, and (D) sample from an XCB core with strong drilling overprint. Open squares and solid circles represent the projection of the magnetization vector endpoints onto the vertical and horizontal planes, respectively. NRM = natural remanent magnetization.

A Sample 334-U1378B-5H-2, $104-106 \mathrm{~cm}$

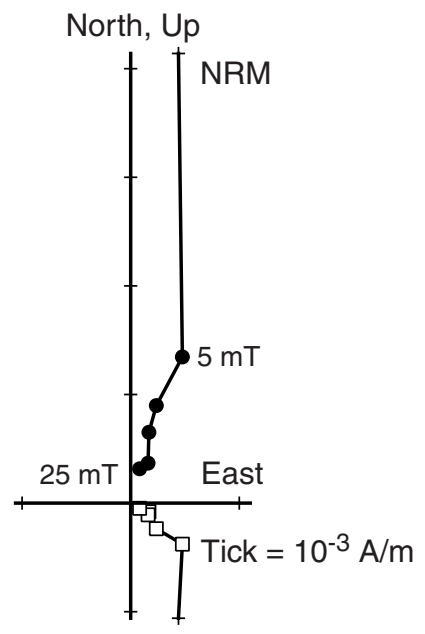

Cample 334-U1378B-40X-2,
$92-94 \mathrm{~cm}$

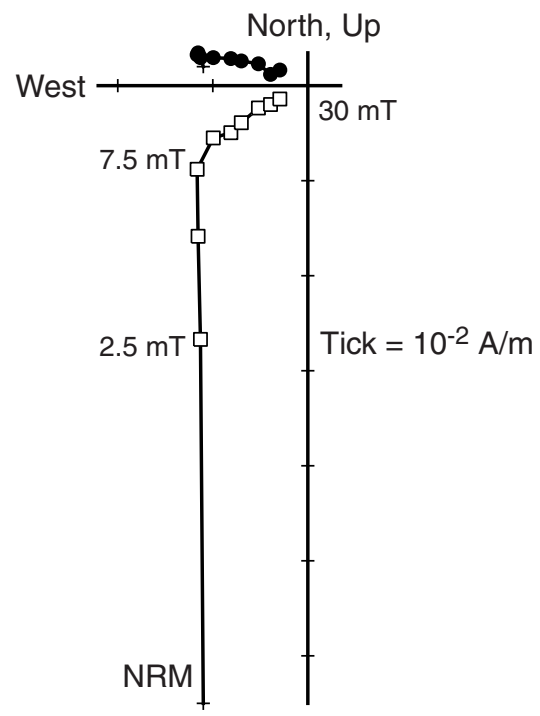

B Sample 334-U1378B-15H-3, $63-65 \mathrm{~cm}$

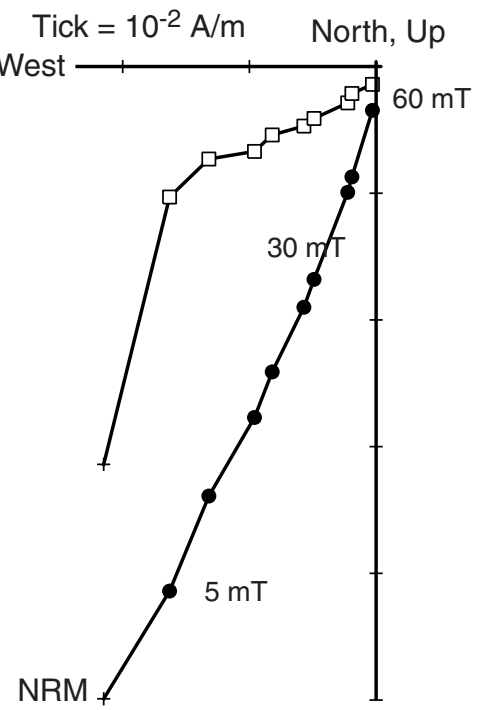

D Sample 334-U1378B-33X-5, $24-26 \mathrm{~cm}$

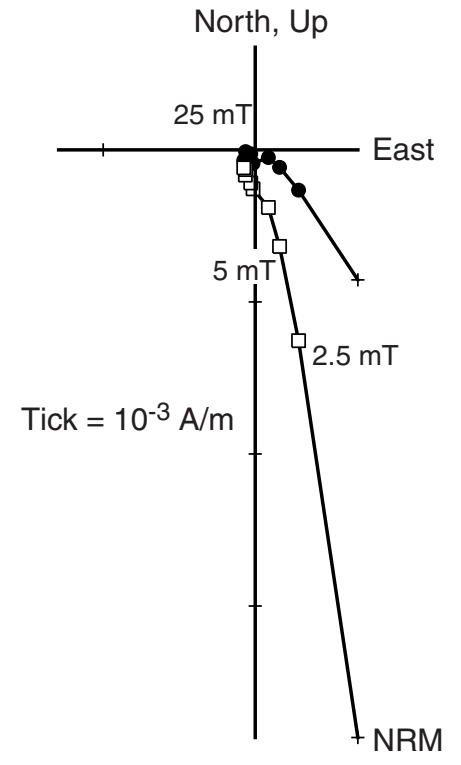


Figure F33. Plots of declination variations of paleomagnetic measurements on archive sections after $15 \mathrm{mT}$ AF demagnetization for APC cores in Hole U1378B plotted in (A) IODP coordinates and (B) geomagnetic frame based on Flexit tool orientation. Red stars represent characteristic remanent magnetization of discrete samples, and dashed red horizontal lines represent core boundaries.

A

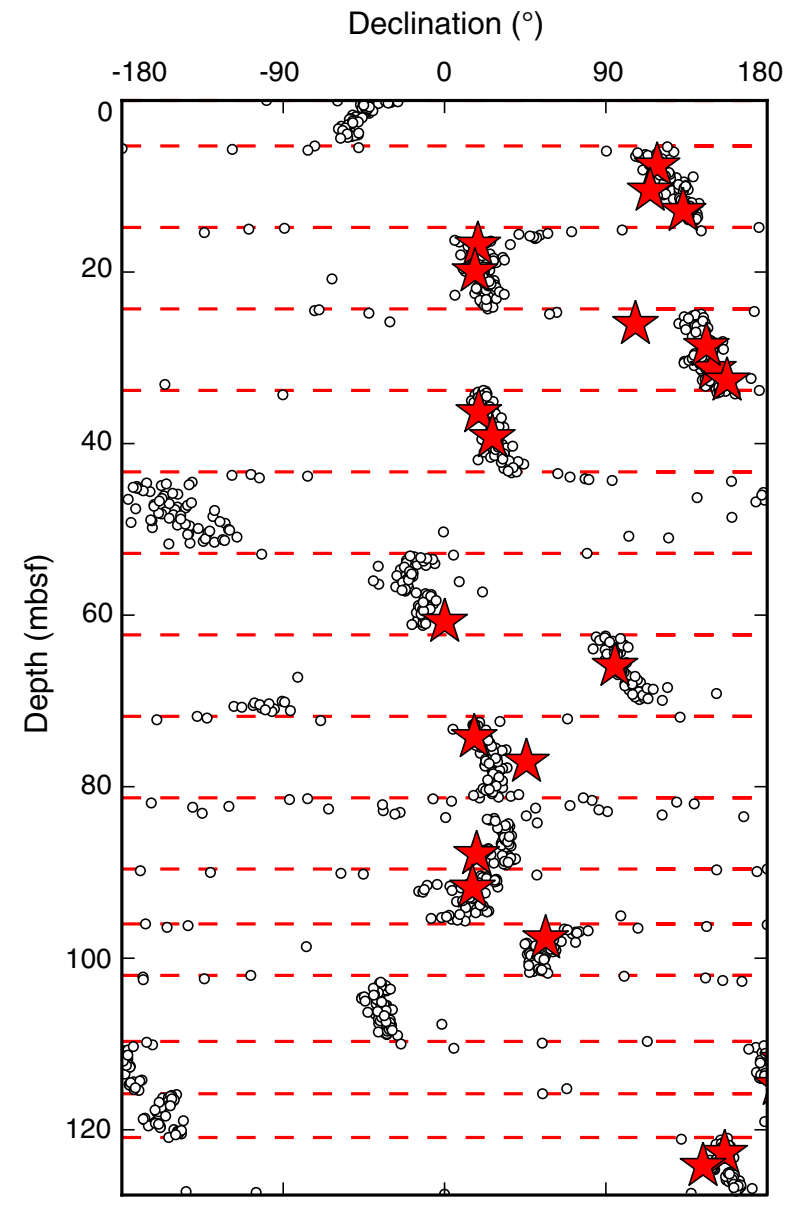

B

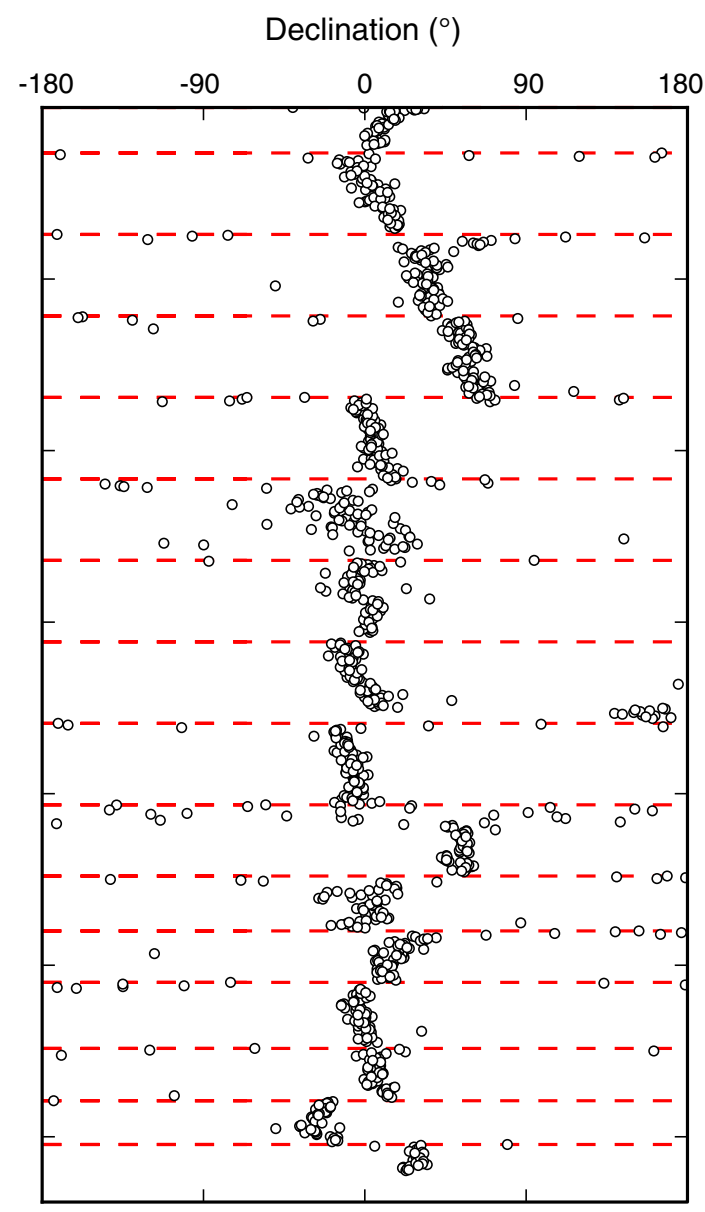


Figure F34. Plots of rock magnetic results from Samples 334-U1378B-15H-3, 63-65 cm ( 90-190 mbsf; red); $5 \mathrm{H}-2,104-106 \mathrm{~cm}$ (above the interval; blue); and 32X-2, 94-96 cm (below the interval; green). A. Isothermal remanent magnetization (IRM) acquisition curves showing saturation before $500 \mathrm{mT}$ for all three samples. B. Alternating-field (AF) demagnetization curves of IRM (solid lines) and anhysteretic remanent magnetization (ARM; dashed lines) showing moderate magnetic stability.
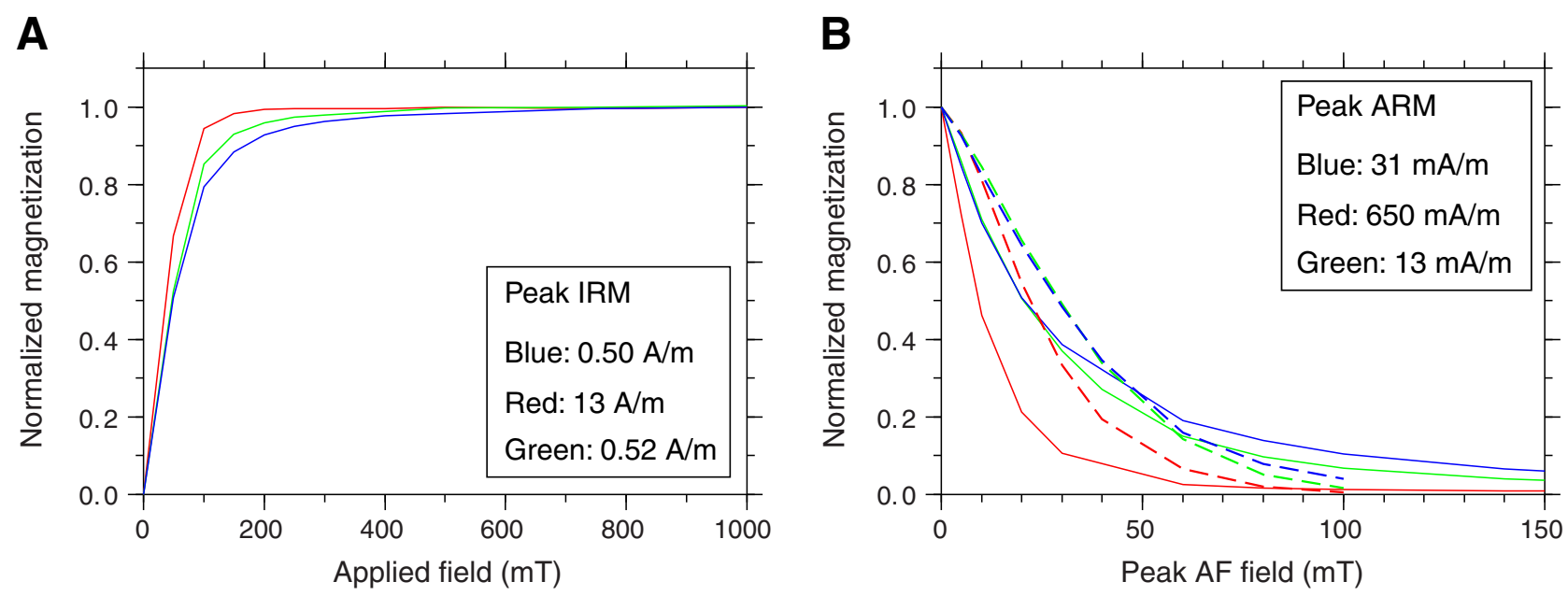
Figure F35. Monitoring and quality control LWD logs, Hole U1378A. D = hole diameter from density measurements, $\mathrm{U}=$ hole diameter from ultrasonic measurements, $\mathrm{ROP}=$ rate of penetration.

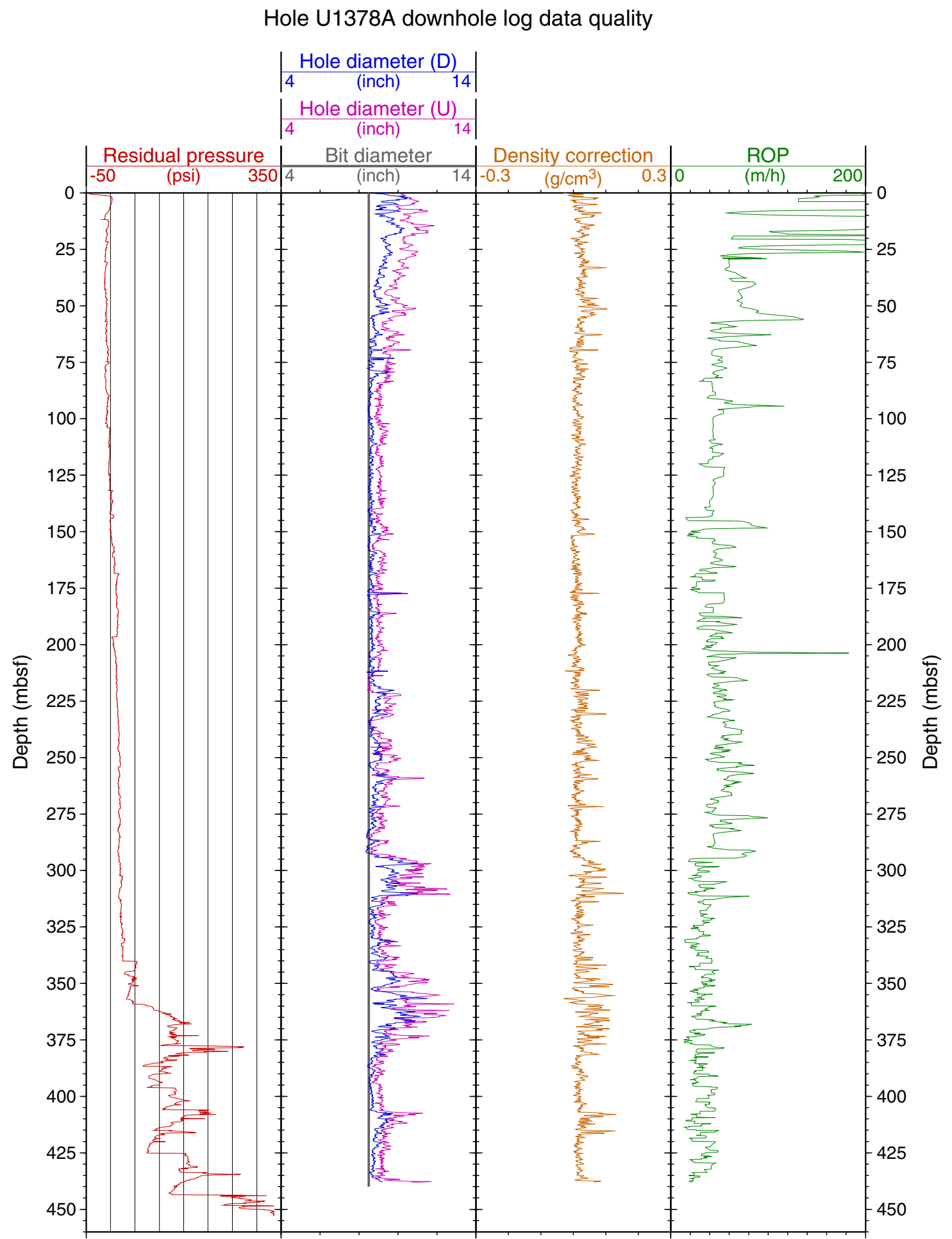


Figure F36. Summary of LWD measurements, Hole U1378A. GVR = geoVISION tool, ARC = arcVISION tool, $\mathrm{PEF}=$ photoelectric factor, IDRO $=$ image-derived density, $\mathrm{RHOB}=$ bulk density, $\mathrm{RING}=$ resistivity measured by the ring electrode (geoVISION tool), $\mathrm{P} 16 \mathrm{~B}=$ phase-shift resistivity measured at a 16 inch source-receiver separation (arcVISION tool), A40B $=$ attenuation resistivity measured at a 40 inch source-receiver separation (arcVISION tool).

Hole U1378A downhole log data summary

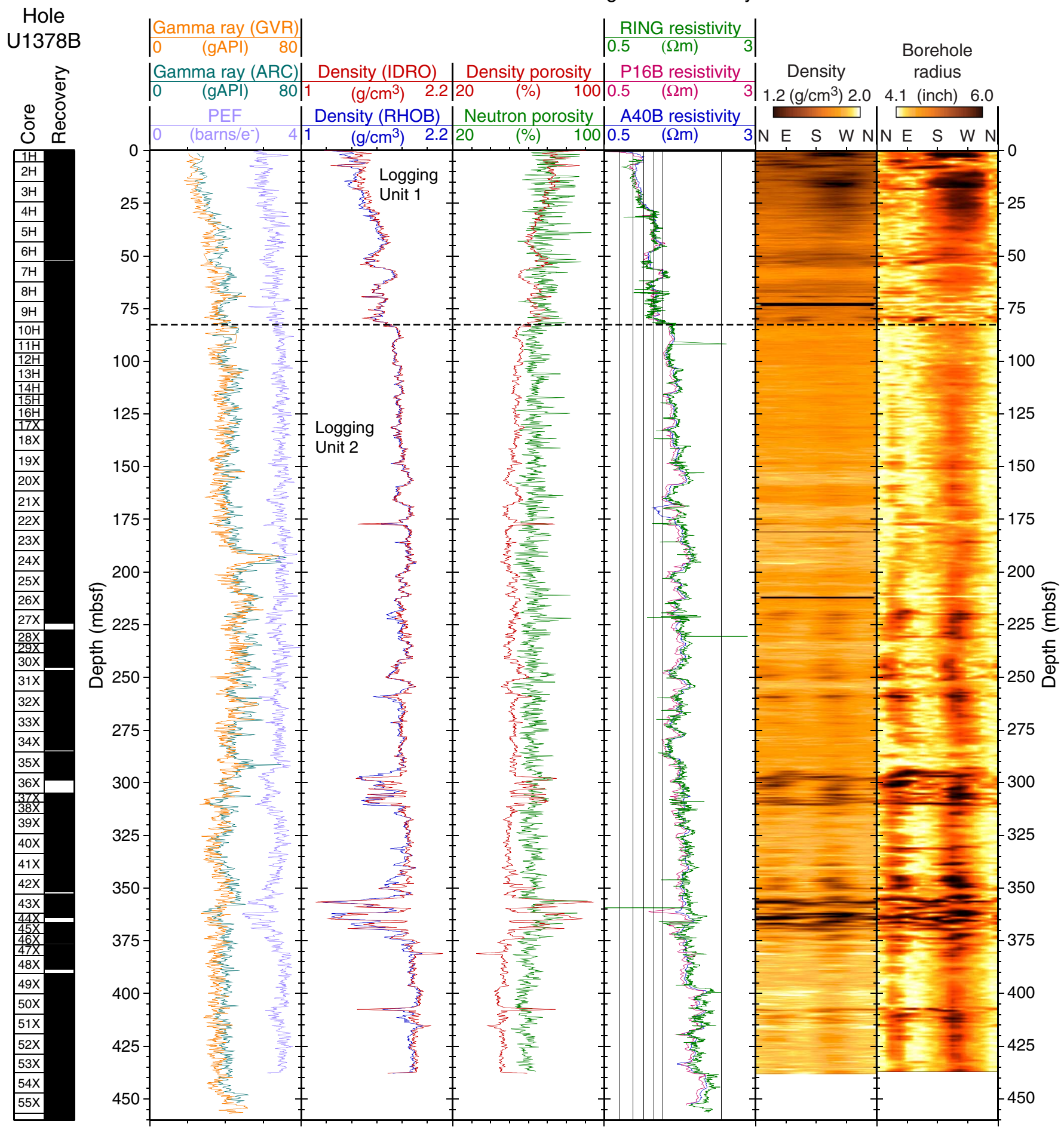


Figure F37. Example borehole images of distinct narrow breakouts observed in Hole U1378A.

Hole U1378A borehole radius images
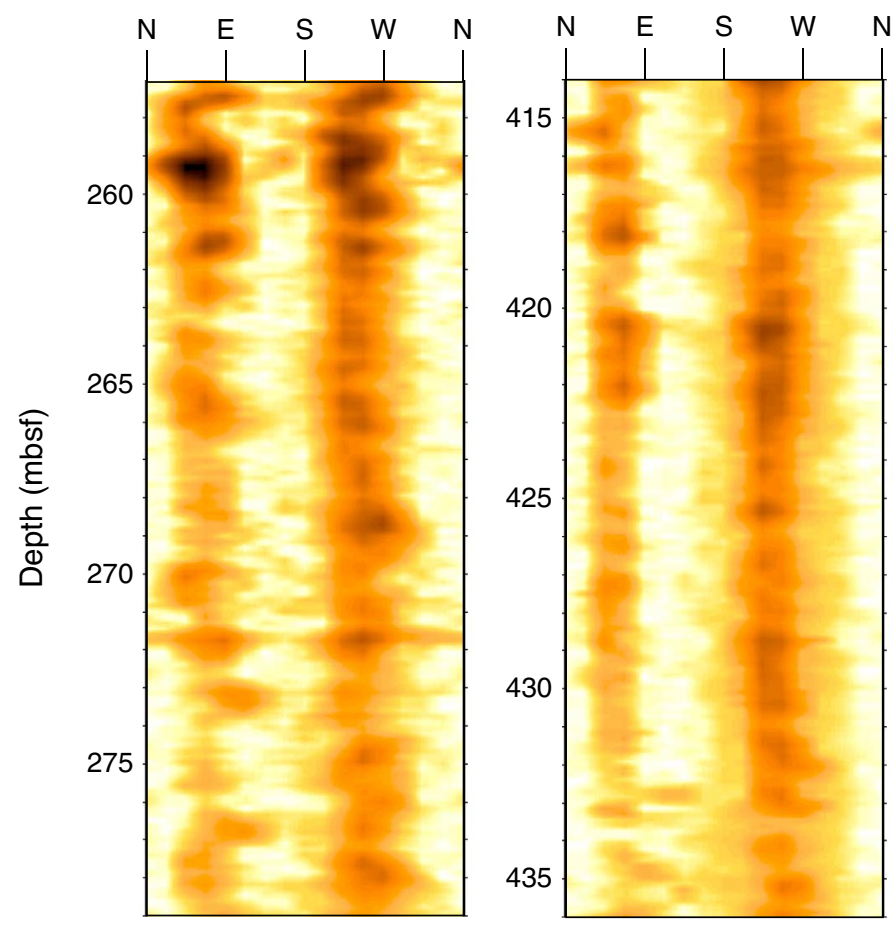

4.1

(inch)

$$
6.0
$$

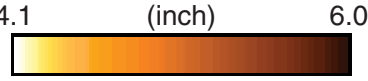


Figure F38. Comparison of LWD log data in Hole U1378A (colored curves) and core measurements in Hole U1378B (black circles). $\mathrm{NGR}=$ natural gamma ray core measurement, $\mathrm{ARC}=$ arcVISION tool, GVR $=$ geoVISION tool, IDRO = image-derived density (adnVISION tool), GRA = gamma ray attenuation, MAD = moisture and density.

\section{Hole U1378A downhole log and Hole U1378B core data comparison}

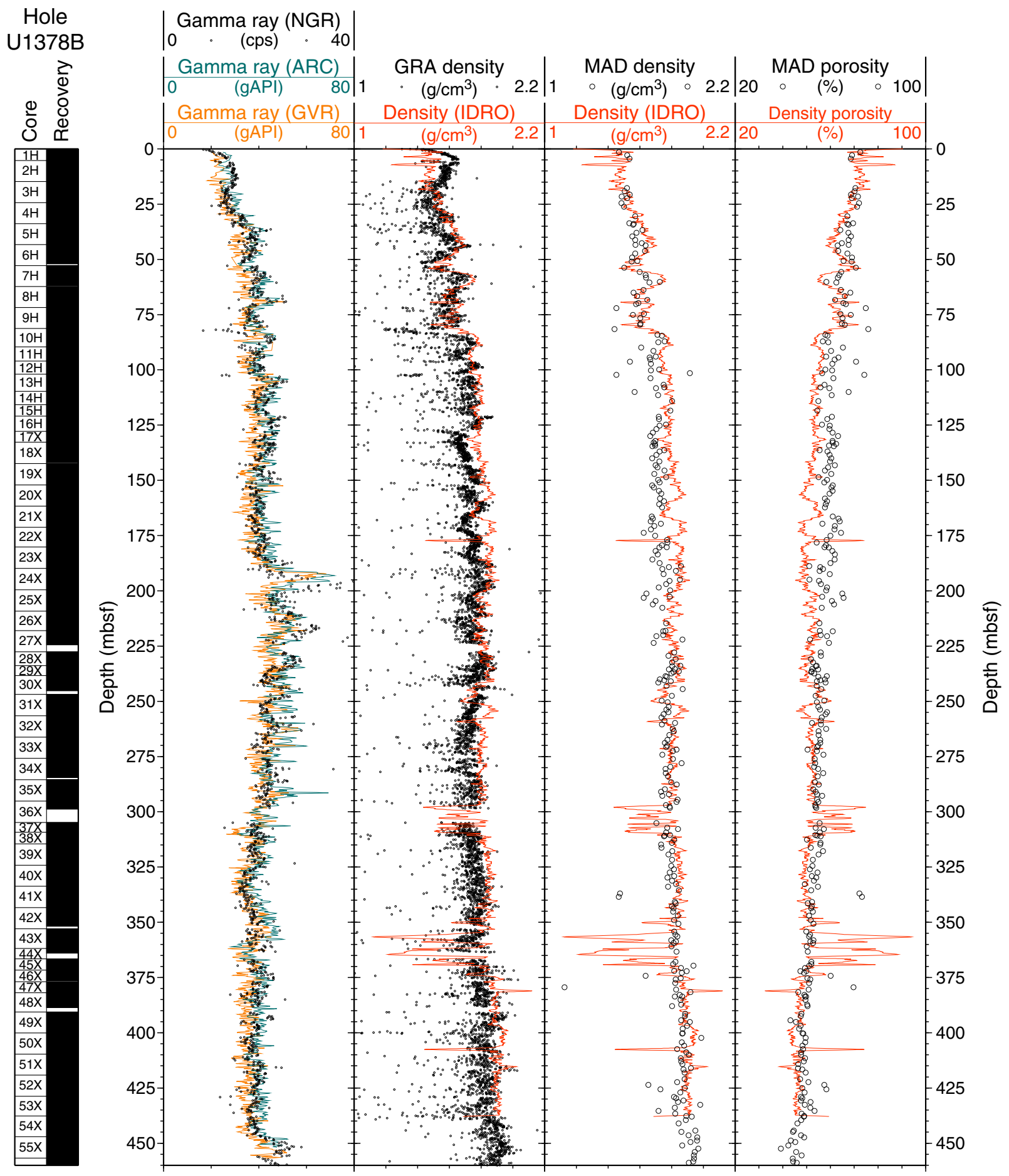


Table T1. Operations summary, Site U1378. (Continued on next page.)

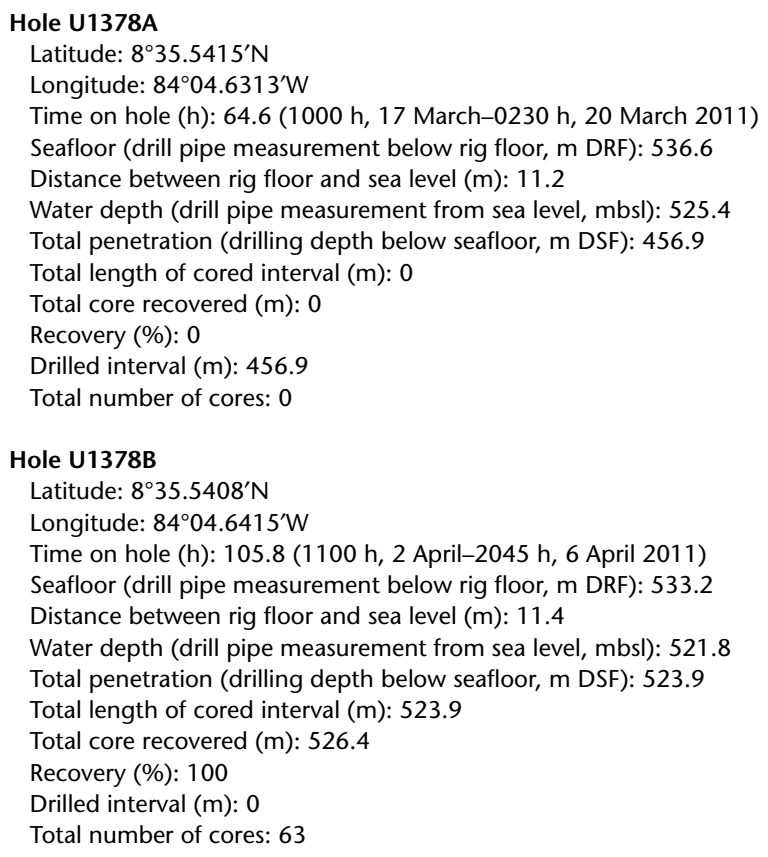

\begin{tabular}{|c|c|c|c|c|c|c|c|c|c|}
\hline \multirow[b]{2}{*}{ Core } & \multirow[b]{2}{*}{$\begin{array}{l}\text { Date } \\
(2011)\end{array}$} & \multirow[b]{2}{*}{$\begin{array}{l}\text { Time } \\
(\mathrm{h})\end{array}$} & \multicolumn{2}{|c|}{ Depth DSF $(m)$} & \multirow[b]{2}{*}{$\begin{array}{l}\text { Interval advanced } \\
(\mathrm{m})\end{array}$} & \multicolumn{2}{|c|}{ Depth CSF (m) } & \multirow{2}{*}{$\begin{array}{l}\text { Length of core } \\
\text { recovered } \\
(\mathrm{m})\end{array}$} & \multirow[b]{2}{*}{$\begin{array}{l}\text { Recovery } \\
\text { (\%) }\end{array}$} \\
\hline & & & $\begin{array}{c}\text { Top of cored } \\
\text { interval }\end{array}$ & $\begin{array}{l}\text { Bottom of } \\
\text { cored interval }\end{array}$ & & $\begin{array}{c}\text { Top of cored } \\
\text { interval }\end{array}$ & $\begin{array}{c}\text { Bottom of } \\
\text { cored interval }\end{array}$ & & \\
\hline $\begin{array}{l}\text { 334-U1378A- } \\
11\end{array}$ & $18 \mathrm{Mar}$ & 2300 & \multicolumn{7}{|c|}{${ }^{* \star \star \star \star}$ Drilled from 0.0 to $456.9 \mathrm{~m} \mathrm{DSF}{ }^{* \star \star \star *}$} \\
\hline 334-U1378B- & & & & & & & & & \\
\hline $1 \mathrm{H}$ & $02 \mathrm{Apr}$ & 2120 & 0.0 & 5.3 & 5.3 & 0.0 & 5.4 & 5.36 & 101 \\
\hline $2 \mathrm{H}$ & $02 \mathrm{Apr}$ & 2200 & 5.3 & 14.8 & 9.5 & 5.3 & 15.2 & 9.91 & 104 \\
\hline $3 \mathrm{H}$ & $02 \mathrm{Apr}$ & 2240 & 14.8 & 24.3 & 9.5 & 14.8 & 24.9 & 10.11 & 106 \\
\hline $4 \mathrm{H}$ & $02 \mathrm{Apr}$ & 2345 & 24.3 & 33.8 & 9.5 & 24.3 & 34.7 & 10.37 & 109 \\
\hline $5 \mathrm{H}$ & $03 \mathrm{Apr}$ & 0025 & 33.8 & 43.3 & 9.5 & 33.8 & 43.8 & 10.02 & 105 \\
\hline $6 \mathrm{H}$ & $03 \mathrm{Apr}$ & 0100 & 43.3 & 52.8 & 9.5 & 43.3 & 52.1 & 8.76 & 92 \\
\hline $7 \mathrm{H}$ & $03 \mathrm{Apr}$ & 0215 & 52.8 & 62.3 & 9.5 & 52.8 & 61.9 & 9.07 & 95 \\
\hline $8 \mathrm{H}$ & $03 \mathrm{Apr}$ & 0320 & 62.3 & 71.8 & 9.5 & 62.3 & 71.3 & 9.55 & 101 \\
\hline $9 \mathrm{H}$ & $03 \mathrm{Apr}$ & 0400 & 71.8 & 81.3 & 9.5 & 71.8 & 81.6 & 9.75 & 103 \\
\hline $10 \mathrm{H}$ & $03 \mathrm{Apr}$ & 0520 & 81.3 & 89.6 & 8.3 & 81.3 & 89.6 & 8.29 & 100 \\
\hline $11 \mathrm{H}$ & $03 \mathrm{Apr}$ & 0610 & 89.6 & 96.0 & 6.4 & 89.6 & 96.0 & 6.39 & 100 \\
\hline $12 \mathrm{H}$ & $03 \mathrm{Apr}$ & 0705 & 96.0 & 102.0 & 6.0 & 96.0 & 102.1 & 6.06 & 101 \\
\hline $13 \mathrm{H}$ & $03 \mathrm{Apr}$ & 0835 & 102.0 & 109.7 & 7.7 & 102.0 & 109.7 & 7.74 & 101 \\
\hline $14 \mathrm{H}$ & $03 \mathrm{Apr}$ & 1025 & 109.7 & 115.8 & 6.1 & 109.7 & 115.8 & 6.13 & 100 \\
\hline $15 \mathrm{H}$ & $03 \mathrm{Apr}$ & 1130 & 115.8 & 120.9 & 5.1 & 115.8 & 120.9 & 5.12 & 100 \\
\hline $16 \mathrm{H}$ & $03 \mathrm{Apr}$ & 1225 & 120.9 & 127.8 & 6.9 & 120.9 & 127.8 & 6.93 & 100 \\
\hline $17 X$ & $03 \mathrm{Apr}$ & 1415 & 127.8 & 132.7 & 4.9 & 127.8 & 135.1 & 7.25 & 148 \\
\hline $18 X$ & $03 \mathrm{Apr}$ & 1500 & 132.7 & 142.4 & 9.7 & 132.7 & 142.0 & 9.34 & 96 \\
\hline $19 x$ & $03 \mathrm{Apr}$ & 1555 & 142.4 & 152.1 & 9.7 & 142.4 & 152.2 & 9.78 & 101 \\
\hline $20 x$ & $03 \mathrm{Apr}$ & 1705 & 152.1 & 161.7 & 9.6 & 152.1 & 162.0 & 9.86 & 103 \\
\hline $21 x$ & $03 \mathrm{Apr}$ & 1800 & 161.7 & 171.3 & 9.6 & 161.7 & 171.5 & 9.76 & 102 \\
\hline $22 x$ & $03 \mathrm{Apr}$ & 1900 & 171.3 & 180.2 & 8.9 & 171.3 & 180.9 & 9.59 & 108 \\
\hline $23 x$ & $03 \mathrm{Apr}$ & 2000 & 180.2 & 189.8 & 9.6 & 180.2 & 190.0 & 9.75 & 102 \\
\hline $24 X$ & $03 \mathrm{Apr}$ & 2100 & 189.8 & 199.5 & 9.7 & 189.8 & 199.9 & 10.10 & 104 \\
\hline $25 x$ & $03 \mathrm{Apr}$ & 2225 & 199.5 & 209.2 & 9.7 & 199.5 & 209.3 & 9.83 & 101 \\
\hline $26 x$ & $03 \mathrm{Apr}$ & 2330 & 209.2 & 218.0 & 8.8 & 209.2 & 219.2 & 9.96 & 113 \\
\hline $27 X$ & $04 \mathrm{Apr}$ & 0115 & 218.0 & 227.6 & 9.6 & 218.0 & 224.4 & 6.41 & 67 \\
\hline $28 \mathrm{X}$ & $04 \mathrm{Apr}$ & 0300 & 227.6 & 233.8 & 6.2 & 227.6 & 237.5 & 9.87 & 159 \\
\hline $29 X$ & $04 \mathrm{Apr}$ & 0400 & 233.8 & 238.3 & 4.5 & 233.8 & 242.0 & 8.15 & 181 \\
\hline $30 x$ & $04 \mathrm{Apr}$ & 0530 & 238.3 & 246.9 & 8.6 & 238.3 & 245.2 & 6.94 & 81 \\
\hline $31 x$ & $04 \mathrm{Apr}$ & 0710 & 246.9 & 256.5 & 9.6 & 246.9 & 256.4 & 9.51 & 99 \\
\hline $32 x$ & $04 \mathrm{Apr}$ & 0815 & 256.5 & 266.2 & 9.7 & 256.5 & 266.2 & 9.71 & 100 \\
\hline $33 x$ & $04 \mathrm{Apr}$ & 0910 & 266.2 & 275.8 & 9.6 & 266.2 & 275.6 & 9.39 & 98 \\
\hline $34 X$ & $04 \mathrm{Apr}$ & 1005 & 275.8 & 285.5 & 9.7 & 275.8 & 284.5 & 8.70 & 90 \\
\hline $35 x$ & $04 \mathrm{Apr}$ & 1110 & 285.5 & 295.2 & 9.7 & 285.5 & 295.3 & 9.80 & 101 \\
\hline
\end{tabular}


Table T1 (continued).

\begin{tabular}{|c|c|c|c|c|c|c|c|c|c|}
\hline \multirow[b]{2}{*}{ Core } & \multirow[b]{2}{*}{$\begin{array}{l}\text { Date } \\
(2011)\end{array}$} & \multirow[b]{2}{*}{$\begin{array}{l}\text { Time } \\
\text { (h) }\end{array}$} & \multicolumn{2}{|c|}{ Depth DSF (m) } & \multirow[b]{2}{*}{$\begin{array}{l}\text { Interval advanced } \\
(\mathrm{m})\end{array}$} & \multicolumn{2}{|c|}{ Depth CSF (m) } & \multirow{2}{*}{$\begin{array}{l}\text { Length of core } \\
\text { recovered } \\
\text { (m) }\end{array}$} & \multirow[b]{2}{*}{$\begin{array}{l}\text { Recovery } \\
\text { (\%) }\end{array}$} \\
\hline & & & $\begin{array}{c}\text { Top of cored } \\
\text { interval }\end{array}$ & $\begin{array}{l}\text { Bottom of } \\
\text { cored interval }\end{array}$ & & $\begin{array}{l}\text { Top of cored } \\
\text { interval }\end{array}$ & $\begin{array}{l}\text { Bottom of } \\
\text { cored interval }\end{array}$ & & \\
\hline $36 x$ & $04 \mathrm{Apr}$ & 1225 & 295.2 & 304.8 & 9.6 & 295.2 & 298.8 & 3.64 & 38 \\
\hline $37 X$ & $04 \mathrm{Apr}$ & 1325 & 304.8 & 309.3 & 4.5 & 304.8 & 311.5 & 6.68 & 148 \\
\hline $38 x$ & $04 \mathrm{Apr}$ & 1425 & 309.3 & 314.5 & 5.2 & 309.3 & 315.3 & 5.96 & 115 \\
\hline $39 x$ & $04 \mathrm{Apr}$ & 1525 & 314.5 & 324.2 & 9.7 & 314.5 & 324.4 & 9.85 & 102 \\
\hline $40 x$ & $04 \mathrm{Apr}$ & 1645 & 324.2 & 333.7 & 9.5 & 324.2 & 334.0 & 9.75 & 103 \\
\hline $41 X$ & $04 \mathrm{Apr}$ & 1800 & 333.7 & 343.4 & 9.7 & 333.7 & 343.7 & 10.01 & 103 \\
\hline $42 X$ & $04 \mathrm{Apr}$ & 1950 & 343.4 & 353.0 & 9.6 & 343.4 & 351.8 & 8.36 & 87 \\
\hline $43 x$ & $04 \mathrm{Apr}$ & 2140 & 353.0 & 361.9 & 8.9 & 353.0 & 362.0 & 9.04 & 102 \\
\hline $44 X$ & $04 \mathrm{Apr}$ & 2335 & 361.9 & 366.6 & 4.7 & 361.9 & 364.0 & 2.12 & 45 \\
\hline $45 X$ & $05 \mathrm{Apr}$ & 0105 & 366.6 & 371.6 & 5.0 & 366.6 & 373.4 & 6.81 & 136 \\
\hline $46 X$ & $05 \mathrm{Apr}$ & 0245 & 371.6 & 376.9 & 5.3 & 371.6 & 376.6 & 4.97 & 94 \\
\hline $47 X$ & $05 \mathrm{Apr}$ & 0340 & 376.9 & 381.9 & 5.0 & 376.9 & 384.2 & 7.26 & 145 \\
\hline $48 x$ & $05 \mathrm{Apr}$ & 0515 & 381.9 & 390.6 & 8.7 & 381.9 & 388.6 & 6.74 & 77 \\
\hline $49 x$ & $05 \mathrm{Apr}$ & 0705 & 390.6 & 400.1 & 9.5 & 390.6 & 400.9 & 10.28 & 108 \\
\hline $50 x$ & $05 \mathrm{Apr}$ & 0820 & 400.1 & 409.7 & 9.6 & 400.1 & 409.4 & 9.28 & 97 \\
\hline $51 X$ & $05 \mathrm{Apr}$ & 0935 & 409.7 & 419.2 & 9.5 & 409.7 & 419.4 & 9.71 & 102 \\
\hline $52 X$ & $05 \mathrm{Apr}$ & 1045 & 419.2 & 428.8 & 9.6 & 419.2 & 428.8 & 9.59 & 100 \\
\hline $53 x$ & $05 \mathrm{Apr}$ & 1150 & 428.8 & 437.7 & 8.9 & 428.8 & 439.3 & 10.54 & 118 \\
\hline $54 X$ & $05 \mathrm{Apr}$ & 1345 & 437.7 & 447.1 & 9.4 & 437.7 & 447.4 & 9.71 & 103 \\
\hline $55 X$ & $05 \mathrm{Apr}$ & 1510 & 447.1 & 456.7 & 9.6 & 447.1 & 457.0 & 9.90 & 103 \\
\hline $56 X$ & $05 \mathrm{Apr}$ & 1635 & 456.7 & 466.3 & 9.6 & 456.7 & 466.5 & 9.80 & 102 \\
\hline $57 X$ & $05 \mathrm{Apr}$ & 1805 & 466.3 & 475.9 & 9.6 & 466.3 & 476.2 & 9.90 & 103 \\
\hline $58 x$ & $05 \mathrm{Apr}$ & 1955 & 475.9 & 485.5 & 9.6 & 475.9 & 481.7 & 5.78 & 60 \\
\hline $59 x$ & $05 \mathrm{Apr}$ & 2210 & 485.5 & 495.2 & 9.7 & 485.5 & 495.4 & 9.85 & 102 \\
\hline $60 x$ & $05 \mathrm{Apr}$ & 2340 & 495.2 & 504.6 & 9.4 & 495.2 & 502.7 & 7.47 & 79 \\
\hline $61 X$ & $06 \mathrm{Apr}$ & 0140 & 504.6 & 509.7 & 5.1 & 504.6 & 511.2 & 6.57 & 129 \\
\hline $62 X$ & $06 \mathrm{Apr}$ & 0315 & 509.7 & 514.2 & 4.5 & 509.7 & 513.6 & 3.86 & 86 \\
\hline \multirow[t]{3}{*}{$63 X$} & $06 \mathrm{Apr}$ & 0635 & 514.2 & 523.9 & 9.7 & 514.2 & 523.9 & 9.70 & 100 \\
\hline & & & \multirow{2}{*}{\multicolumn{2}{|c|}{$\begin{array}{l}\text { Advanced total: } \\
\text { Total interval cored: }\end{array}$}} & 980.8 & & & 526.39 & 103 \\
\hline & & & & & 523.9 & & & & \\
\hline
\end{tabular}

$\mathrm{DRF}=$ drilling depth below rig floor, $\mathrm{DSF}=$ drilling depth below seafloor, $\mathrm{CSF}=$ core depth below seafloor. $\mathrm{H}=\mathrm{APC}$ core, $\mathrm{X}=\mathrm{XCB}$ core, $1=$ drilled interval. Time is Universal Time Coordinated.

Table T2. Summary of lithostratigraphic unit thickness from Hole U1378B.

\begin{tabular}{lcccc}
\hline Unit & $\begin{array}{c}\text { Upper contact } \\
(\mathrm{mbs})\end{array}$ & $\begin{array}{c}\text { Lower contact } \\
(\mathrm{mbs})\end{array}$ & $\begin{array}{c}\text { Unit thickness } \\
(\mathrm{m})\end{array}$ & $\begin{array}{c}\text { Cumulative thickness } \\
(\mathrm{m})\end{array}$ \\
\hline I & 0.00 & 127.83 & 127.83 & 127.83 \\
II & 127.83 & 523.90 & 396.07 & 523.90 \\
\hline
\end{tabular}


Table T3. Calcareous nannofossil faunal distribution, Hole U1378B.

\begin{tabular}{|c|c|c|c|c|c|c|c|c|c|c|c|c|c|c|c|c|c|c|}
\hline Core, section & $\begin{array}{l}\text { Depth } \\
\text { (mbsf) }\end{array}$ & $\begin{array}{c}\text { Calcareous } \\
\text { nannofossil zone }\end{array}$ & 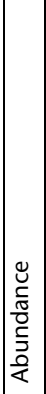 & 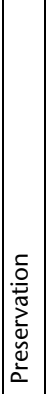 & 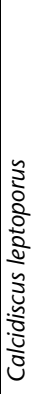 & 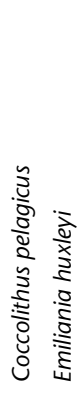 & 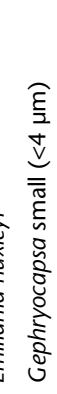 & 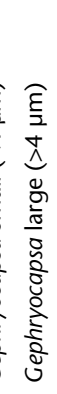 & 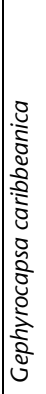 & 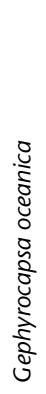 & 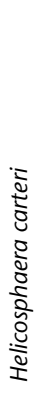 & 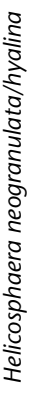 & 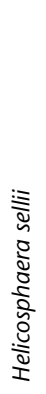 & 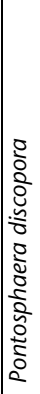 & 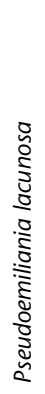 & 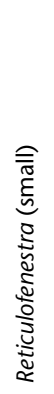 & 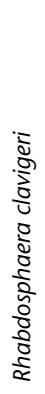 & 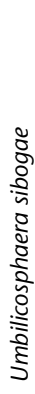 \\
\hline 334-U1378B- & & \multirow{16}{*}{ NN21-NN20 } & & & & & & & & & & & & & & & & \\
\hline $1 \mathrm{H}-\mathrm{CC}$ & 5.34 & & A & $G$ & C & A & $A V$ & $A$ & A & A & A & & & & & & & \\
\hline $5 \mathrm{H}-\mathrm{CC}$ & 43.82 & & A & $G$ & C & A & $A V$ & $A$ & A & A & A & & & & & & $\mathrm{R}$ & \\
\hline 7H-CC & 61.85 & & A & $M$ & C & C & $=A$ & $C$ & C & A & C & & & & & & & \\
\hline $9 \mathrm{H}-\mathrm{CC}$ & 81.58 & & V & G & C & C & $=\mathrm{V}$ & $A$ & A & V & A & $\mathrm{R}$ & & & & & & \\
\hline $11 \mathrm{H}-\mathrm{CC}$ & 95.99 & & V & G & $C$ & $\mathrm{~F}$ & $=V$ & $\mathrm{~V}$ & V & V & A & & & C & & & & \\
\hline $13 \mathrm{H}-\mathrm{CC}$ & 109.72 & & $\mathrm{~V}$ & $G$ & C & C & {$[\mathrm{V}$} & $\mathrm{V}$ & V & V & A & & & C & & & & \\
\hline $15 \mathrm{H}-\mathrm{CC}$ & 120.92 & & A & $G$ & C & C & $C A$ & $C$ & A & V & C & & & & & & $\mathrm{R}$ & \\
\hline $16 \mathrm{H}-\mathrm{CC}$ & 127.94 & & $\mathrm{~V}$ & $G$ & C & C & $=\mathrm{V}$ & $A$ & V & V & A & & & & & & & \\
\hline $17 \mathrm{X}-\mathrm{CC}$ & 135.03 & & $\mathrm{v}$ & $G$ & C & & $\mathrm{V}$ & $C$ & V & V & A & & & & & & & \\
\hline $18 \mathrm{X}-\mathrm{CC}$ & 142.04 & & A & $M$ & $C$ & & A & $C$ & A & A & A & & & & & & & $\mathrm{R}$ \\
\hline 19X-CC & 152.16 & & $\mathrm{~V}$ & $G$ & C & $\mathrm{R}$ & V & $C$ & V & V & A & & & & & & $\mathrm{R}$ & \\
\hline 20X-CC & 161.94 & & $\mathrm{~V}$ & $G$ & C & $\mathrm{R}$ & V & $C$ & V & V & A & & & & & & & \\
\hline $24 X-C C$ & 199.88 & & A & $G$ & C & & V & $C$ & C & A & A & $\mathrm{F}$ & & & $\mathrm{F}$ & & & \\
\hline $25 \mathrm{X}-\mathrm{CC}$ & 209.33 & & C & $G$ & C & & A & $C$ & C & C & C & & & & $\mathrm{R}$ & & & \\
\hline $27 \mathrm{X}-\mathrm{CC}$ & 224.39 & & B & & & & & & & & & & & & & & & \\
\hline $28 \mathrm{X}-\mathrm{CC}$ & 237.47 & \multirow{29}{*}{ NN19 } & A & $G$ & C & & V & $A$ & A & A & C & $\mathrm{F}$ & & $\mathrm{F}$ & $\mathrm{F}$ & & & \\
\hline $30 \mathrm{X}-\mathrm{CC}$ & 245.22 & & A & $G$ & C & & A & $C$ & A & A & A & & & C & & & & \\
\hline $31 \mathrm{X}-\mathrm{CC}$ & 256.40 & & B & & & & & & & & & & & & & & & \\
\hline $32 \mathrm{X}-\mathrm{CC}$ & 266.21 & & A & $M$ & C & $\mathrm{R}$ & A & $C$ & A & A & C & & & & $\mathrm{R}$ & & & \\
\hline $33 \mathrm{X}-\mathrm{CC}$ & 275.57 & & A & $M$ & C & & A & $\mathrm{F}$ & A & A & C & & & C & $\mathrm{R}$ & & $\mathrm{F}$ & $\mathrm{F}$ \\
\hline $34 \mathrm{X}-\mathrm{CC}$ & 284.48 & & A & $M$ & $C$ & $\mathrm{R}$ & A & $C$ & A & A & C & & & & $\mathrm{R}$ & & & \\
\hline $35 X-C C$ & 295.28 & & A & $M$ & C & $\mathrm{F}$ & A & $C$ & A & C & $\mathrm{C}$ & & & & & & & \\
\hline $36 \mathrm{X}-\mathrm{CC}$ & 298.70 & & A & $M$ & C & $\mathrm{R}$ & A & $A$ & A & C & C & & & & & & & \\
\hline $37 X-C C$ & 311.46 & & A & $M$ & C & & A & $A$ & A & C & A & C & & C & $\mathrm{F}$ & & & \\
\hline $38 \mathrm{X}-\mathrm{CC}$ & 315.24 & & C & $M$ & C & $\mathrm{R}$ & C & $C$ & C & C & C & C & $\mathrm{F}$ & C & $\mathrm{F}$ & & $\mathrm{R}$ & \\
\hline $39 \mathrm{X}-\mathrm{CC}$ & 324.33 & & C & $P$ & $C$ & $\mathrm{R}$ & C & & C & C & C & & $\mathrm{R}$ & & $\mathrm{F}$ & & & \\
\hline $40 \mathrm{X}-\mathrm{CC}$ & 333.95 & & $\mathrm{R}$ & $M$ & $R$ & $\mathrm{R}$ & & & & & $\mathrm{F}$ & & $\mathrm{R}$ & & & & & \\
\hline $43 \mathrm{X}-\mathrm{CC}$ & 362.02 & & C & $M$ & & $\mathrm{R}$ & C & $F$ & C & C & C & & & & $\mathrm{F}$ & $\mathrm{F}$ & & \\
\hline $44 \mathrm{X}-\mathrm{CC}$ & 364.02 & & $\mathrm{~F}$ & $M$ & $\mathrm{~F}$ & & C & 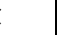 & $\mathrm{F}$ & $\mathrm{F}$ & $\mathrm{F}$ & & & & & $\mathrm{F}$ & & \\
\hline 45X-CC & 373.41 & & C & $M$ & C & $\mathrm{R}$ & A & & & C & C & & & & & C & & \\
\hline $48 \mathrm{X}-\mathrm{CC}$ & 388.64 & & A & $M$ & C & $\mathrm{R}$ & C & & A & & C & & & $F$ & $\mathrm{~F}$ & C & $\mathrm{R}$ & $\mathrm{F}$ \\
\hline $49 \mathrm{X}-\mathrm{CC}$ & 400.86 & & A & $M$ & $C$ & $\mathrm{R}$ & A & & C & $\mathrm{F}$ & A & & $\mathrm{R}$ & $\mathrm{F}$ & $\mathrm{F}$ & C & & \\
\hline $50 \mathrm{X}-\mathrm{CC}$ & 409.36 & & C & $M$ & C & $\mathrm{R}$ & C & & C & & C & & & $\mathrm{F}$ & & C & & \\
\hline 51X-CC & 419.39 & & C & $M$ & C & & V & & C & & C & $\mathrm{F}$ & & & & A & & \\
\hline $52 \mathrm{X}-\mathrm{CC}$ & 428.77 & & C & $M$ & C & & A & & C & & C & C & & & & A & & \\
\hline $53 \mathrm{X}-\mathrm{CC}$ & 439.00 & & C & $M$ & $C$ & $\mathrm{R}$ & A & & C & & C & & & & $\mathrm{F}$ & C & & $\mathrm{R}$ \\
\hline $54 \mathrm{X}-\mathrm{CC}$ & 447.41 & & A & $M$ & $C$ & & V & $C$ & & & C & C & & $\mathrm{F}$ & $\mathrm{F}$ & C & & \\
\hline $55 \mathrm{X}-\mathrm{CC}$ & 456.98 & & A & $M$ & C & & V & A & A & A & C & C & $\mathrm{R}$ & $\mathrm{F}$ & & & & $\mathrm{F}$ \\
\hline $56 \mathrm{X}-\mathrm{CC}$ & 466.36 & & A & $\mathrm{M}$ & C & $\mathrm{R}$ & A & $\mathrm{A}$ & A & A & A & C & & C & & A & & C \\
\hline 57X-CC & 476.18 & & A & $M$ & $C$ & & A & $C$ & A & C & A & C & C & C & & A & & \\
\hline 59X-CC & 495.33 & & A & $M$ & $C$ & & A & & & & A & C & A & C & $\mathrm{R}$ & C & & $\mathrm{R}$ \\
\hline $61 X-C C$ & 511.15 & & B & & & & & & & & & & & & & & & \\
\hline $62 X-C C$ & 513.54 & & C & $M$ & $\mathrm{~F}$ & C & & & $\mathrm{F}$ & $\mathrm{R}$ & C & $\mathrm{F}$ & $\mathrm{F}$ & & $\mathrm{F}$ & C & & $\mathrm{F}$ \\
\hline 63X-CC & 523.90 & & A & $G$ & C & $\mathrm{F}$ & & & & & A & C & $\mathrm{V}$ & C & $\mathrm{R}$ & A & & \\
\hline
\end{tabular}

Abundance: $V=$ very abundant, $A=$ abundant, $C=$ common, $F=$ few, $R=$ rare, $B=$ barren. Preservation: $G=$ good, $M=$ moderate, $P=$ poor. See "Paleontology and biostratigraphy" in the "Methods" chapter (Expedition 334 Scientists, 2012) for abundance and preservation definitions. 
Table T4. Interstitial water chemistry, Hole U1378B. (Continued on next page.)

\begin{tabular}{|c|c|c|c|c|c|c|c|c|c|c|c|c|c|}
\hline \multirow{2}{*}{$\begin{array}{l}\text { Core, section, } \\
\text { interval (cm) }\end{array}$} & \multirow{2}{*}{$\begin{array}{l}\text { Depth } \\
\text { (mbsf) }\end{array}$} & \multirow{2}{*}{$\begin{array}{l}\text { Volume } \\
(\mathrm{mL})\end{array}$} & \multirow[b]{2}{*}{ Salinity } & \multirow{2}{*}{$\begin{array}{c}\text { Alkalinity } \\
(\mathrm{mM})\end{array}$} & \multirow[b]{2}{*}{$\mathrm{pH}$} & \multirow{2}{*}{$\underset{(\mathrm{mM})}{\mathrm{Cl}}$} & & & $\mathrm{NH}_{4}$ & $\mathrm{Ca}$ & K & $\mathrm{Mg}$ & $\mathrm{Na}$ \\
\hline & & & & & & & IC & ICP & $(\mathrm{mM})$ & $(\mathrm{mM})$ & $(\mathrm{mM})$ & $(\mathrm{mM})$ & $(\mathrm{mM})$ \\
\hline 334-U1378B- & & & & & & & & & & & & & \\
\hline $1 \mathrm{H}-1,138-150$ & 1.38 & 50 & 35 & 8.75 & 7.61 & 557 & 20.70 & 21.25 & 0.67 & 7.38 & 10.80 & 48.64 & 453 \\
\hline $1 \mathrm{H}-2,138-150$ & 2.88 & 50 & 33 & 11.10 & 7.53 & 556 & 15.98 & 16.39 & 0.84 & 5.42 & 10.69 & 47.65 & 448 \\
\hline $1 \mathrm{H}-3,138-150$ & 4.38 & 50 & 32.5 & 12.43 & 7.64 & 557 & 13.94 & 14.01 & 0.97 & 4.41 & 10.91 & 47.64 & 451 \\
\hline $1 \mathrm{H}-4,46-58$ & 4.96 & 50 & 32 & 12.89 & 7.65 & 557 & 12.09 & 13.23 & 1.02 & 4.22 & 11.14 & 48.08 & 453 \\
\hline $2 \mathrm{H}-1,138-150$ & 6.68 & 50 & 32 & 15.02 & 7.69 & 557 & 9.65 & 10.54 & 1.06 & 4.19 & 10.75 & 46.88 & 438 \\
\hline $2 \mathrm{H}-2,138-150$ & 8.18 & 50 & 32 & 17.47 & 7.68 & 555 & 7.49 & 8.26 & 1.06 & 4.06 & 10.34 & 44.10 & 419 \\
\hline $2 \mathrm{H}-3,138-150$ & 9.68 & 50 & 32 & 21.08 & 7.68 & 554 & 4.93 & 5.98 & 1.11 & 4.16 & 9.97 & 43.29 & 415 \\
\hline $2 \mathrm{H}-4,138-150$ & 11.18 & 50 & 32 & 28.19 & 7.65 & 554 & 1.74 & 2.03 & 1.24 & 4.34 & 10.66 & 45.42 & 440 \\
\hline $2 \mathrm{H}-5,138-150$ & 12.68 & 50 & 32 & 30.31 & 7.64 & 554 & ND & 0.85 & 1.63 & 4.31 & 10.20 & 45.69 & 437 \\
\hline $2 \mathrm{H}-6,138-150$ & 14.18 & 50 & 32 & 31.13 & 7.69 & 553 & ND & 0.79 & 1.76 & 4.02 & 9.45 & 42.68 & 412 \\
\hline $2 \mathrm{H}-7,54-66$ & 14.84 & 50 & 32 & 31.84 & 7.63 & 553 & ND & 0.69 & 2.21 & 3.93 & 9.52 & 43.05 & 417 \\
\hline $3 \mathrm{H}-1,138-150$ & 16.18 & - & 32 & 32.07 & 7.62 & 549 & ND & 0.91 & 2.51 & 3.37 & 9.25 & 40.45 & 397 \\
\hline $3 \mathrm{H}-2,138-150$ & 17.68 & - & 32 & 33.94 & 7.70 & 548 & ND & 1.19 & 2.81 & 3.50 & 9.82 & 43.62 & 423 \\
\hline $3 \mathrm{H}-3,138-150$ & 19.18 & 60 & 32 & 35.68 & 7.72 & 548 & ND & 0.51 & 3.56 & 3.40 & 10.32 & 44.50 & 435 \\
\hline $3 \mathrm{H}-4,138-150$ & 20.68 & 50 & 32 & 36.36 & 7.64 & 547 & ND & 0.53 & 3.73 & 3.20 & 10.00 & 44.43 & 431 \\
\hline $3 \mathrm{H}-5,138-150$ & 22.18 & 50 & 32 & 36.16 & 7.77 & 546 & ND & 0.61 & 4.25 & 3.02 & 10.50 & 43.74 & 428 \\
\hline $3 \mathrm{H}-6,133-145$ & 23.63 & 54 & 32 & 36.85 & 7.71 & 546 & ND & 0.53 & 4.26 & 2.77 & 9.42 & 40.57 & 397 \\
\hline $3 \mathrm{H}-7,58-70$ & 24.38 & 34 & 32 & 36.26 & 7.70 & 0 & ND & 0.50 & 4.43 & 3.02 & 10.54 & 43.78 & 434 \\
\hline $4 \mathrm{H}-3,138-150$ & 27.79 & 44 & 32 & 33.43 & 7.66 & 546 & ND & 0.73 & 4.59 & 2.54 & 10.37 & 42.74 & 429 \\
\hline $4 \mathrm{H}-6,138-150$ & 32.29 & 40 & 30.5 & 27.56 & 7.76 & 546 & ND & 0.52 & 4.33 & 1.99 & 10.81 & 40.59 & 427 \\
\hline $5 \mathrm{H}-2,138-150$ & 36.68 & 48 & 30 & 18.15 & 7.79 & 546 & ND & 0.60 & 3.81 & 1.89 & 10.56 & 36.02 & 422 \\
\hline $5 \mathrm{H}-6,138-150$ & 42.68 & 50 & 30 & 15.32 & 7.62 & 547 & ND & 0.53 & 3.34 & 2.58 & 10.24 & 36.12 & 432 \\
\hline $6 \mathrm{H}-2,138-150$ & 46.18 & 52 & 30.5 & 16.66 & 7.79 & 545 & ND & 0.67 & 3.38 & 2.20 & 10.68 & 37.89 & 433 \\
\hline $6 \mathrm{H}-5,138-150$ & 50.68 & 40 & 30 & 17.43 & 7.67 & 541 & ND & 0.49 & 3.47 & 2.18 & 9.89 & 38.85 & 427 \\
\hline 7H-2, 138-150 & 55.68 & 52 & 30 & 22.05 & 7.60 & 541 & ND & 0.54 & 3.81 & 2.16 & 9.82 & 40.53 & 423 \\
\hline 7H-5, 138-150 & 60.18 & 40 & 30.5 & 23.15 & 7.72 & 539 & ND & 0.57 & 4.07 & 2.44 & 10.00 & 41.64 & 426 \\
\hline $8 \mathrm{H}-2,138-150$ & 63.82 & 52 & 31 & 26.49 & 7.73 & 540 & ND & 1.06 & 4.42 & 2.63 & 9.92 & 43.11 & 426 \\
\hline $8 \mathrm{H}-5,138-150$ & 68.32 & 50 & 30 & 23.26 & 8.15 & 540 & ND & 0.59 & 5.03 & 1.61 & 10.94 & 39.38 & 416 \\
\hline $9 \mathrm{H}-2,138-150$ & 74.68 & 48 & 30 & 26.66 & 8.01 & 543 & ND & 0.87 & 5.37 & 1.95 & 9.42 & 37.85 & 386 \\
\hline $9 \mathrm{H}-5,130-142$ & 79.10 & 50 & 30 & 26.66 & 8.00 & 539 & ND & 0.63 & 5.46 & 2.37 & 9.74 & 41.88 & 411 \\
\hline $10 \mathrm{H}-2,130-142$ & 84.10 & 48 & 30 & 27.92 & 7.79 & 539 & ND & 0.94 & 5.40 & 2.47 & 9.14 & 42.30 & 409 \\
\hline $10 \mathrm{H}-4,138-150$ & 87.10 & 40 & 30 & 26.53 & 7.98 & 540 & ND & 0.68 & 5.69 & 2.09 & 9.39 & 41.21 & 411 \\
\hline $11 \mathrm{H}-3,138-150$ & 93.98 & 42 & 29.5 & 23.74 & 8.26 & 539 & ND & 0.83 & 6.23 & 2.01 & 10.05 & 39.84 & 417 \\
\hline $12 \mathrm{H}-3,138-150$ & 99.83 & 45 & 29.5 & 25.46 & 7.93 & 534 & ND & 0.62 & 5.80 & 2.56 & 8.76 & 42.15 & 411 \\
\hline $13 \mathrm{H}-4,138-150$ & 107.88 & 48 & 29 & 22.64 & 8.04 & 533 & ND & 0.77 & 5.73 & 2.42 & 8.83 & 41.65 & 409 \\
\hline $14 \mathrm{H}-3,138-150$ & 114.09 & 45 & 29 & 19.62 & 8.05 & 532 & ND & 0.65 & 5.85 & 2.25 & 8.62 & 39.93 & 407 \\
\hline $15 \mathrm{H}-2,118-130$ & 118.48 & 50 & 29 & 18.57 & 8.10 & 531 & ND & 0.71 & 5.63 & 2.78 & 8.10 & 38.25 & 395 \\
\hline $16 \mathrm{H}-3,133-145$ & 124.78 & 49 & 29 & 13.90 & 8.34 & 530 & ND & 0.80 & 5.94 & 2.34 & 8.67 & 36.71 & 402 \\
\hline 17X-3, 133-145 & 132.13 & 42 & 29 & 18.96 & 7.90 & 524 & 1.33 & 1.26 & 5.69 & 3.21 & 7.04 & 35.56 & 371 \\
\hline $18 \mathrm{X}-3,113-130$ & 136.33 & 40 & 29 & 19.52 & 7.83 & 517 & ND & 0.54 & 5.69 & 3.72 & 7.69 & 38.08 & 399 \\
\hline 19X-5, 71-96 & 148.55 & 45 & 29 & 16.67 & 8.05 & 515 & ND & 1.29 & 5.65 & 4.07 & 7.45 & 36.38 & 392 \\
\hline $20 X-5,130-153$ & 158.24 & 42 & 28 & 14.13 & 7.96 & 512 & 1.17 & 1.97 & 5.81 & 4.35 & 7.95 & 35.63 & 403 \\
\hline $21 X-7,68-93$ & 169.64 & 21 & 28 & 17.73 & 7.74 & 508 & ND & 1.37 & 5.36 & 5.05 & 7.00 & 34.63 & 386 \\
\hline $22 X-5,88-105$ & 178.18 & 18 & 28 & - & - & 506 & ND & 0.80 & 5.32 & 4.92 & 6.85 & 32.72 & 377 \\
\hline $23 X-6,109-126$ & 188.79 & 18 & 27.5 & - & - & 503 & ND & 1.24 & 5.65 & 4.66 & 8.02 & 32.11 & 400 \\
\hline $24 X-4,122-150$ & 194.91 & 24 & 27 & 13.74 & 7.95 & 488 & ND & 1.23 & 5.36 & 3.86 & 7.43 & 28.99 & 375 \\
\hline $25 X-3,74-90$ & 202.69 & 19 & 27 & - & - & 486 & ND & 1.66 & 5.36 & 3.52 & 7.75 & 26.18 & 372 \\
\hline $26 X-4,98-115$ & 214.68 & 24 & 26 & 13.09 & 7.75 & 483 & 2.76 & 2.47 & 5.11 & 4.10 & 7.72 & 26.83 & 375 \\
\hline $27 X-2,100-127$ & 220.00 & 17 & 26 & 14.46 & 7.74 & 481 & ND & 0.83 & 5.02 & 3.34 & 7.52 & 25.76 & 372 \\
\hline $28 X-7,33-65$ & 236.43 & 17 & 26 & 17.54 & 7.84 & 470 & ND & 0.74 & 5.02 & 2.75 & 7.26 & 24.69 & 351 \\
\hline $29 X-3,45-83$ & 236.75 & 26 & 26 & 19.03 & 7.84 & 465 & ND & 0.75 & 5.15 & 2.93 & 7.99 & 26.04 & 371 \\
\hline $30 \times-2,110-145$ & 240.90 & 38 & 26 & 20.83 & 7.83 & 480 & ND & 1.66 & 5.37 & 3.47 & 8.39 & 26.81 & 377 \\
\hline $31 X-4,118-150$ & 252.48 & 24 & 26 & 21.62 & 7.78 & 465 & ND & 0.95 & 5.37 & 3.45 & 8.05 & 26.00 & 370 \\
\hline $32 X-3,73-105$ & 259.83 & 60 & 25 & 22.86 & 7.64 & 457 & 1.81 & 1.66 & 5.67 & 3.85 & 8.84 & 25.41 & 374 \\
\hline $33 X-5,58-94$ & 271.89 & 20 & 24.5 & 20.69 & 7.98 & 454 & 3.83 & 2.65 & 5.63 & 4.23 & 9.21 & 24.56 & 371 \\
\hline $34 X-2,86-122$ & 277.96 & 50 & 24.5 & 22.19 & 7.85 & - & 2.71 & 2.48 & 6.54 & 4.22 & 9.33 & 24.02 & 369 \\
\hline $35 X-5,98-130$ & 292.08 & 45 & 24 & 19.44 & 7.87 & 444 & 1.83 & 2.26 & 6.93 & 4.33 & 7.89 & 22.55 & 342 \\
\hline $36 X-2,93-125$ & 297.63 & 50 & 25 & 19.45 & 7.87 & 445 & 3.10 & 2.85 & 7.24 & 4.49 & 8.67 & 23.67 & 362 \\
\hline $37 X-2,91-123$ & 307.21 & 50 & 24 & - & - & - & 1.62 & 1.97 & 7.63 & 4.72 & 8.26 & 22.28 & 356 \\
\hline $38 X-1,118-150$ & 310.48 & 40 & 24 & 17.96 & 7.86 & 445 & 2.98 & 3.74 & 7.67 & 5.44 & 8.43 & 24.17 & 364 \\
\hline $39 X-5,118-150$ & 321.68 & 35 & 24 & 17.89 & 7.94 & 432 & ND & 1.74 & 7.93 & 5.46 & 8.08 & 22.42 & 358 \\
\hline $40 X-4,80-92$ & 329.10 & 40 & 23 & 15.31 & 8.00 & 430 & ND & 1.93 & 8.03 & 5.23 & 7.19 & 20.95 & 335 \\
\hline $41 X-5,104-136$ & 340.74 & 48 & 23 & 13.37 & 7.98 & 423 & ND & 1.62 & 7.83 & 5.66 & 7.08 & 20.86 & 345 \\
\hline $42 X-3,64-96$ & 347.04 & 36 & 24 & 9.50 & 7.90 & - & 2.88 & 2.84 & 7.45 & 6.58 & 6.61 & 22.04 & 350 \\
\hline $43 X-5,55-87$ & 358.71 & 32 & 22.5 & 9.24 & 7.86 & 416 & 1.87 & 2.00 & 6.97 & 7.63 & 6.07 & 20.23 & 339 \\
\hline $45 X-3,55-88$ & 369.65 & 30 & 22 & 6.36 & 7.85 & 418 & 1.80 & 2.45 & 7.05 & 7.55 & 5.35 & 18.73 & 317 \\
\hline $46 X-2,115-150$ & 374.25 & 30 & 22 & 6.08 & 8.04 & 409 & 1.97 & 2.31 & 6.72 & 8.32 & 5.43 & 19.29 & 334 \\
\hline $47 X-2,95-130$ & 379.35 & 30 & 22 & 4.91 & 7.99 & 411 & 1.28 & 2.05 & 6.46 & 8.29 & 4.81 & 18.12 & 316 \\
\hline
\end{tabular}


Table T4 (continued).

\begin{tabular}{|c|c|c|c|c|c|c|c|c|c|c|c|c|c|}
\hline \multirow{2}{*}{$\begin{array}{l}\text { Core, section, } \\
\text { interval }(\mathrm{cm})\end{array}$} & \multirow{2}{*}{$\begin{array}{l}\text { Depth } \\
\text { (mbsf) }\end{array}$} & \multirow{2}{*}{$\begin{array}{l}\text { Volume } \\
(\mathrm{mL})\end{array}$} & \multirow[b]{2}{*}{ Salinity } & \multirow{2}{*}{$\begin{array}{l}\text { Alkalinity } \\
(\mathrm{mM})\end{array}$} & \multirow[b]{2}{*}{$\mathrm{pH}$} & \multirow{2}{*}{$\begin{array}{c}\mathrm{Cl} \\
(\mathrm{mM})\end{array}$} & \multicolumn{2}{|c|}{$\mathrm{SO}_{4}(\mathrm{mM})$} & \multirow{2}{*}{$\begin{array}{c}\mathrm{NH}_{4} \\
(\mathrm{mM})\end{array}$} & \multirow{2}{*}{$\begin{array}{c}\mathrm{Ca} \\
(\mathrm{mM})\end{array}$} & \multirow{2}{*}{$\begin{array}{c}\mathrm{K} \\
(\mathrm{mM})\end{array}$} & \multirow{2}{*}{$\begin{array}{c}\mathrm{Mg} \\
(\mathrm{mM})\end{array}$} & \multirow{2}{*}{$\begin{array}{c}\mathrm{Na} \\
(\mathrm{mM})\end{array}$} \\
\hline & & & & & & & IC & ICP & & & & & \\
\hline $48 X-1,96-122$ & 382.86 & 34 & 22 & 3.98 & 8.13 & 415 & 2.91 & 3.53 & 6.09 & 8.60 & 5.38 & 20.03 & 337 \\
\hline $49 X-3,106-138$ & 394.66 & 12 & 22 & 3.69 & 8.12 & 405 & 2.72 & 2.22 & 6.18 & 8.18 & 4.79 & 18.23 & 322 \\
\hline $50 X-2,97-129$ & 402.27 & 40 & 22 & 4.37 & 8.03 & 401 & 1.90 & 2.29 & 6.00 & 8.32 & 4.55 & 18.23 & 323 \\
\hline $51 X-5,85-117$ & 415.96 & 12 & 21 & - & - & 397 & 1.60 & 1.70 & 5.37 & 8.77 & 4.07 & 17.17 & 317 \\
\hline $52 X-5,70-102$ & 425.00 & 30 & 21 & 2.57 & 8.22 & 391 & 2.05 & 2.39 & 5.39 & 9.39 & 3.97 & 15.14 & 313 \\
\hline $53 X-3,53-85$ & 430.70 & 11 & 21 & - & - & 385 & 1.74 & 2.08 & 4.93 & 10.42 & 3.86 & 14.28 & 326 \\
\hline $54 X-5,104-140$ & 444.24 & 48 & 20.5 & 1.84 & 8.29 & 387 & 2.06 & 2.11 & 5.00 & 9.53 & 4.22 & 11.41 & 319 \\
\hline $55 X-2,81-117$ & 448.81 & 15 & 20.5 & - & - & 388 & 2.10 & - & 4.74 & - & - & - & - \\
\hline $56 X-2,64-76$ & 458.24 & 40 & 20.5 & 2.75 & 8.31 & 384 & 1.96 & 2.38 & 4.38 & 7.39 & 4.61 & 12.58 & 321 \\
\hline $57 X-3,63-99$ & 469.33 & 10 & 20.5 & - & - & 382 & 2.12 & 2.75 & 4.85 & 5.81 & 5.17 & 12.32 & 328 \\
\hline $58 X-2,90-126$ & 478.26 & 0.4 & 20.5 & - & - & - & - & - & - & - & - & - & - \\
\hline $59 X-4,93-125$ & 489.66 & 12 & 20.5 & - & - & 380 & 2.63 & 2.99 & 4.70 & 5.30 & 5.54 & 13.21 & 331 \\
\hline $60 X-4,60-92$ & 499.72 & 16 & 20 & 5.75 & 8.26 & 366 & ND & 1.87 & 4.38 & 4.82 & 5.15 & 12.40 & 312 \\
\hline $61 X-4,102-138$ & 510.12 & 10 & 18 & - & - & 355 & ND & 1.30 & 4.22 & 4.73 & 5.01 & 12.23 & 303 \\
\hline $62 X-1,54-81$ & 510.24 & 12 & 19 & - & - & - & 2.75 & 2.77 & 4.54 & 5.71 & 5.28 & 15.03 & 323 \\
\hline $63 X-4,84-122$ & 518.74 & 12 & 19 & - & - & - & 1.67 & 2.29 & 4.39 & 5.58 & 5.36 & 14.60 & 315 \\
\hline
\end{tabular}

IC = ion chromatography, ICP = inductively coupled plasma-atomic emission spectroscopy. $-=$ not measured, ND $=$ not detectable.

Table T5. Gas geochemistry, Site U1378. (Continued on next page.)

\begin{tabular}{|c|c|c|c|c|c|c|c|c|}
\hline $\begin{array}{l}\text { Average depth } \\
\text { (mbsf) }\end{array}$ & $\begin{array}{c}\mathrm{CH}_{4} \\
\text { (ppmv) }\end{array}$ & $\begin{array}{c}\mathrm{C}_{2} \mathrm{H}_{6} \\
\text { (ppmv) }\end{array}$ & $\begin{array}{l}\mathrm{C}_{3} \mathrm{H}_{6}+\mathrm{C}_{3} \mathrm{H}_{8} \\
\text { (ppmv) }\end{array}$ & $\begin{array}{l}\text { iso- } \mathrm{C}_{4} \mathrm{H}_{10} \\
\text { (ppmv) }\end{array}$ & $\begin{array}{l}n-\mathrm{C}_{4} \mathrm{H}_{10} \\
(\mathrm{ppmv})\end{array}$ & $\begin{array}{l}\text { iso- } \mathrm{C}_{5} \mathrm{H}_{12} \\
\text { (ppmv) }\end{array}$ & $\begin{array}{l}n-\mathrm{C}_{5} \mathrm{H}_{12} \\
(\mathrm{ppmv})\end{array}$ & $\mathrm{CH}_{4} /\left(\mathrm{C}_{2} \mathrm{H}_{6}+\mathrm{C}_{3} \mathrm{H}_{8}\right)$ \\
\hline 8.1 & 42.71 & 0.7 & 1.2 & 0.4 & 0.5 & 0.6 & 0.0 & 22.41 \\
\hline 9.7 & 93.57 & 0.0 & 0.0 & 0.0 & 0.0 & 0.0 & 0.0 & ND \\
\hline 11.2 & 427.17 & 1.1 & 0.5 & 0.0 & 0.0 & 0.0 & 0.0 & 266.24 \\
\hline 12.7 & $6,047.34$ & 1.1 & 0.5 & 0.0 & 0.0 & 0.0 & 0.0 & $3,778.37$ \\
\hline 14.1 & $24,515.19$ & 3.1 & 0.0 & 0.0 & 0.0 & 0.0 & 0.0 & $7,963.32$ \\
\hline 16.2 & $32,809.20$ & 2.4 & 0.8 & 0.0 & 0.4 & 0.6 & 0.0 & $10,114.43$ \\
\hline 17.6 & $40,216.63$ & 2.9 & 0.8 & 0.0 & 0.0 & 0.8 & 0.0 & $10,858.15$ \\
\hline 19.2 & $73,823.04$ & 4.8 & 0.9 & 0.5 & 0.0 & 1.6 & 0.0 & $12,958.00$ \\
\hline 20.7 & $55,873.26$ & 3.2 & 0.6 & 0.3 & 0.0 & 1.5 & 0.0 & $15,026.67$ \\
\hline 23.6 & $24,466.80$ & 2.9 & 0.7 & 0.6 & 0.0 & 2.7 & 0.0 & $6,677.39$ \\
\hline 32.2 & $8,936.08$ & 1.8 & 0.4 & 0.0 & 0.0 & 0.0 & 0.0 & $4,089.07$ \\
\hline 42.6 & $8,536.09$ & 1.6 & 0.0 & 0.0 & 0.0 & 0.3 & 0.0 & $5,236.26$ \\
\hline 50.6 & $10,596.87$ & 2.1 & 0.4 & 0.0 & 0.0 & 0.0 & 0.0 & $4,222.21$ \\
\hline 60.0 & $9,122.99$ & 1.5 & 0.0 & 0.0 & 0.0 & 0.0 & 0.0 & $6,146.75$ \\
\hline 68.2 & $51,194.44$ & 6.5 & 0.0 & 0.0 & 0.0 & 0.0 & 0.0 & $7,826.86$ \\
\hline 79.0 & $8,066.33$ & 1.8 & 0.4 & 0.0 & 0.0 & 0.0 & 0.0 & $3,729.30$ \\
\hline 86.9 & $14,547.42$ & 2.7 & 0.4 & 0.0 & 0.0 & 0.0 & 0.0 & $4,592.34$ \\
\hline 93.9 & $11,750.46$ & 2.3 & 0.8 & 0.0 & 0.0 & 0.4 & 0.0 & $3,827.20$ \\
\hline 99.8 & $9,465.91$ & 1.9 & 0.5 & 0.0 & 0.0 & 0.0 & 0.0 & $3,872.85$ \\
\hline 107.8 & $11,262.82$ & 2.0 & 0.5 & 0.0 & 0.0 & 0.3 & 0.0 & $4,488.49$ \\
\hline 114.0 & $9,346.14$ & 1.2 & 0.4 & 0.0 & 0.0 & 0.7 & 0.0 & $5,661.25$ \\
\hline 118.4 & $8,653.30$ & 1.9 & 0.6 & 0.3 & 0.0 & 1.1 & 0.0 & $3,510.81$ \\
\hline 132.1 & $11,349.37$ & 3.3 & 0.7 & 0.0 & 0.0 & 0.3 & 0.0 & $2,858.31$ \\
\hline 136.3 & $6,108.27$ & 1.5 & 0.6 & 0.0 & 0.0 & 0.0 & 0.0 & $2,825.12$ \\
\hline 148.5 & $6,882.14$ & 2.3 & 1.1 & 0.0 & 0.0 & 0.0 & 0.0 & $2,055.75$ \\
\hline 158.2 & $11,052.34$ & 3.8 & 0.7 & 0.0 & 0.0 & 0.0 & 0.0 & $2,467.36$ \\
\hline 169.6 & $11,221.09$ & 4.0 & 0.5 & 0.0 & 0.0 & 0.0 & 0.0 & $2,525.27$ \\
\hline 178.2 & $5,766.59$ & 2.8 & 0.0 & 0.0 & 0.0 & 0.0 & 0.0 & $2,055.70$ \\
\hline 188.8 & $8,204.33$ & 3.1 & 0.0 & 0.0 & 0.0 & 0.0 & 0.0 & $2,646.73$ \\
\hline 194.8 & $7,226.50$ & 2.9 & 0.0 & 0.0 & 0.0 & 0.0 & 0.0 & $2,510.39$ \\
\hline 207.3 & $4,970.17$ & 2.9 & 0.5 & 0.0 & 0.0 & 0.0 & 0.0 & $1,443.36$ \\
\hline 214.7 & $8,425.89$ & 4.3 & 0.0 & 0.0 & 0.0 & 0.0 & 0.0 & $1,958.55$ \\
\hline 220.3 & $9,953.31$ & 6.0 & 0.7 & 0.0 & 0.0 & 0.0 & 0.0 & $1,502.38$ \\
\hline 236.4 & $4,601.54$ & 3.1 & 0.0 & 0.0 & 0.0 & 0.0 & 0.0 & $1,503.01$ \\
\hline 237.2 & $3,200.46$ & 1.7 & 0.0 & 0.0 & 0.0 & 0.0 & 0.0 & $1,834.59$ \\
\hline 240.8 & $9,702.74$ & 5.5 & 0.5 & 0.0 & 0.0 & 0.0 & 0.0 & $1,616.65$ \\
\hline 252.5 & $7,573.68$ & 4.4 & 0.5 & 0.0 & 0.0 & 0.0 & 0.0 & $1,556.26$ \\
\hline 259.8 & $22,208.20$ & 13.4 & 0.9 & 0.0 & 0.0 & 0.0 & 0.0 & $1,546.00$ \\
\hline 270.2 & $11,212.03$ & 6.5 & 0.7 & 0.0 & 0.0 & 0.0 & 0.0 & $1,548.05$ \\
\hline 277.9 & $7,729.57$ & 5.7 & 0.4 & 0.0 & 0.0 & 0.0 & 0.0 & $1,270.16$ \\
\hline 292.1 & $5,628.18$ & 4.1 & 0.5 & 0.0 & 0.0 & 0.0 & 0.0 & $1,234.29$ \\
\hline
\end{tabular}


Table T5 (continued).

\begin{tabular}{|c|c|c|c|c|c|c|c|c|}
\hline $\begin{array}{l}\text { Average depth } \\
\text { (mbsf) }\end{array}$ & $\begin{array}{c}\mathrm{CH}_{4} \\
\text { (ppmv) }\end{array}$ & $\begin{array}{c}\mathrm{C}_{2} \mathrm{H}_{6} \\
\text { (ppmv) }\end{array}$ & $\begin{array}{l}\mathrm{C}_{3} \mathrm{H}_{6}+\mathrm{C}_{3} \mathrm{H}_{8} \\
\text { (ppmv) }\end{array}$ & $\begin{array}{l}\text { iso- } \mathrm{C}_{4} \mathrm{H}_{10} \\
\text { (ppmv) }\end{array}$ & $\begin{array}{l}n-\mathrm{C}_{4} \mathrm{H}_{10} \\
(\mathrm{ppm})\end{array}$ & $\begin{array}{l}\text { iso- } \mathrm{C}_{5} \mathrm{H}_{12} \\
\text { (ppmv) }\end{array}$ & $\begin{array}{l}n-\mathrm{C}_{5} \mathrm{H}_{12} \\
(\mathrm{ppm} v)\end{array}$ & $\mathrm{CH}_{4} /\left(\mathrm{C}_{2} \mathrm{H}_{6}+\mathrm{C}_{3} \mathrm{H}_{8}\right)$ \\
\hline 310.5 & $11,563.68$ & 7.1 & 0.5 & 0.0 & 0.0 & 0.0 & 0.0 & $1,522.37$ \\
\hline 321.7 & $11,898.52$ & 8.8 & 0.5 & 0.0 & 0.0 & 0.0 & 0.0 & $1,278.96$ \\
\hline 329.0 & $10,564.46$ & 7.5 & 0.5 & 0.0 & 0.0 & 0.0 & 0.0 & $1,324.41$ \\
\hline 340.7 & $4,718.49$ & 4.3 & 0.0 & 0.0 & 0.0 & 0.0 & 0.0 & $1,088.80$ \\
\hline 347.0 & $16,174.42$ & 14.4 & 1.4 & 0.0 & 0.0 & 0.0 & 0.0 & $1,026.59$ \\
\hline 358.7 & $10,564.67$ & 7.6 & 0.6 & 0.0 & 0.0 & 0.0 & 0.0 & $1,288.85$ \\
\hline 369.6 & $11,730.96$ & 9.5 & 0.6 & 0.0 & 0.0 & 0.0 & 0.0 & $1,163.94$ \\
\hline 374.2 & $12,545.13$ & 8.3 & 0.5 & 0.0 & 0.0 & 0.0 & 0.0 & $1,426.79$ \\
\hline 379.7 & $4,618.86$ & 4.7 & 0.0 & 0.0 & 0.0 & 0.0 & 0.0 & 977.38 \\
\hline 382.8 & $4,495.48$ & 5.4 & 0.5 & 0.0 & 0.0 & 0.0 & 0.0 & 761.96 \\
\hline 394.3 & $9,863.05$ & 7.5 & 0.5 & 0.0 & 0.0 & 0.0 & 0.0 & $1,244.10$ \\
\hline 402.2 & $2,519.17$ & 3.6 & 1.8 & 0.7 & 0.9 & 1.4 & 1.8 & 467.36 \\
\hline 413.9 & $4,969.38$ & 4.3 & 0.9 & 0.4 & 0.3 & 0.5 & 0.0 & 950.99 \\
\hline 415.9 & $6,519.27$ & 4.3 & 0.5 & 0.0 & 0.0 & 0.0 & 0.0 & $1,367.97$ \\
\hline 425.0 & $5,170.06$ & 4.3 & 0.7 & 0.0 & 0.0 & 0.6 & 0.0 & $1,042.00$ \\
\hline 433.7 & $2,902.12$ & 2.8 & 0.4 & 0.0 & 0.0 & 0.0 & 0.0 & 898.90 \\
\hline 444.2 & $1,925.86$ & 1.8 & 0.7 & 0.0 & 0.0 & 0.4 & 0.0 & 750.03 \\
\hline 448.8 & $6,338.91$ & 5.6 & 2.4 & 0.7 & 0.7 & 1.3 & 0.7 & 786.50 \\
\hline 458.2 & $4,227.40$ & 4.4 & 1.7 & 0.5 & 0.4 & 0.8 & 0.0 & 699.77 \\
\hline 469.3 & $14,170.86$ & 9.6 & 3.6 & 0.6 & 0.5 & 1.3 & 0.0 & $1,079.10$ \\
\hline 478.2 & $5,457.97$ & 8.4 & 2.6 & 0.4 & 0.0 & 0.6 & 0.0 & 495.58 \\
\hline 489.6 & $5,356.72$ & 4.5 & 0.8 & 0.0 & 0.0 & 0.0 & 0.0 & 998.91 \\
\hline 499.6 & $4,396.23$ & 4.5 & 0.7 & 0.0 & 0.0 & 0.0 & 0.0 & 837.29 \\
\hline 510.1 & $8,696.54$ & 9.7 & 1.7 & 0.5 & 0.4 & 0.7 & 0.7 & 759.56 \\
\hline 510.2 & $4,295.47$ & 5.2 & 1.2 & 0.0 & 0.0 & 0.3 & 0.0 & 675.56 \\
\hline 518.7 & $9,531.57$ & 11.2 & 3.0 & 1.5 & 0.4 & 1.9 & 0.0 & 668.56 \\
\hline
\end{tabular}

Samples preserved with $10 \% \mathrm{KCl}$ solution (NZ samples; see "Geochemistry"). ND = not defined.

Table T6. Concentration of carbon and nitrogen, Site U1378. (Continued on next page.)

\begin{tabular}{|c|c|c|c|c|c|c|c|}
\hline \multirow[b]{2}{*}{ Core, section } & \multicolumn{3}{|c|}{ Depth (mbsf) } & \multirow{2}{*}{$\begin{array}{c}\text { TC } \\
\text { (wt\%) }\end{array}$} & \multirow{2}{*}{$\begin{array}{c}\mathrm{TN} \\
(w t \%)\end{array}$} & \multirow{2}{*}{$\begin{array}{c}\text { TIC } \\
\text { (wt\%) }\end{array}$} & \multirow{2}{*}{$\begin{array}{l}\text { TOC } \\
\text { (wt\%) }\end{array}$} \\
\hline & Top & Bottom & Average & & & & \\
\hline \multicolumn{8}{|l|}{ 334-U1378B- } \\
\hline $1 \mathrm{H}-1$ & 1.38 & 1.40 & 1.39 & 3.20 & 0.273 & 1.21 & 1.99 \\
\hline $1 \mathrm{H}-2$ & 2.88 & 2.90 & 2.89 & 2.61 & 0.234 & 1.02 & 1.59 \\
\hline $1 \mathrm{H}-3$ & 4.38 & 4.40 & 4.39 & 2.64 & 0.213 & 1.16 & 1.48 \\
\hline $1 \mathrm{H}-4$ & 4.96 & 4.98 & 4.97 & 2.74 & 0.186 & 1.46 & 1.28 \\
\hline $2 \mathrm{H}-2$ & 8.18 & 8.20 & 8.19 & 2.62 & 0.204 & 1.01 & 1.61 \\
\hline $2 \mathrm{H}-3$ & 9.68 & 9.70 & 9.69 & 2.64 & 0.211 & 1.09 & 1.55 \\
\hline $2 \mathrm{H}-4$ & 11.18 & 11.20 & 11.19 & 2.35 & 0.198 & 1.00 & 1.35 \\
\hline $2 \mathrm{H}-5$ & 12.68 & 12.70 & 12.69 & 2.53 & 0.154 & 1.05 & 1.48 \\
\hline $2 \mathrm{H}-6$ & 14.18 & 14.20 & 14.19 & 1.99 & 0.136 & 0.49 & 1.50 \\
\hline $2 \mathrm{H}-7$ & 14.84 & 14.86 & 14.85 & 2.22 & 0.137 & 0.66 & 1.56 \\
\hline $3 \mathrm{H}-1$ & 16.18 & 16.20 & 16.19 & 2.81 & 0.196 & 1.13 & 1.68 \\
\hline $3 \mathrm{H}-2$ & 17.68 & 17.70 & 17.69 & 2.04 & 0.146 & 0.72 & 1.32 \\
\hline $3 \mathrm{H}-3$ & 19.18 & 19.20 & 19.19 & 2.61 & 0.172 & - & - \\
\hline $3 \mathrm{H}-4$ & 20.68 & 20.70 & 20.69 & 2.50 & 0.140 & 1.07 & 1.43 \\
\hline $3 \mathrm{H}-5$ & 22.18 & 22.20 & 22.19 & 2.66 & 0.141 & 1.03 & 1.63 \\
\hline $3 \mathrm{H}-6$ & 23.63 & 23.65 & 23.64 & 2.66 & 0.227 & 1.22 & 1.44 \\
\hline $3 \mathrm{H}-7$ & 24.38 & 24.40 & 24.39 & 2.28 & 0.294 & 0.82 & 1.46 \\
\hline $4 \mathrm{H}-3$ & 27.79 & 27.81 & 27.80 & 2.10 & 0.276 & 0.59 & 1.51 \\
\hline $4 \mathrm{H}-6$ & 32.29 & 32.31 & 32.30 & 2.85 & 0.271 & 1.63 & 1.22 \\
\hline $5 \mathrm{H}-2$ & 36.68 & 36.70 & 36.69 & 4.76 & 0.235 & 3.26 & 1.50 \\
\hline $5 \mathrm{H}-6$ & 42.68 & 42.70 & 42.69 & 2.43 & 0.129 & 1.14 & 1.29 \\
\hline $6 \mathrm{H}-2$ & 46.18 & 46.20 & 46.19 & 2.38 & 0.125 & 1.11 & 1.27 \\
\hline $6 \mathrm{H}-5$ & 50.68 & 50.70 & 50.69 & 2.70 & 0.336 & 0.93 & 1.77 \\
\hline $7 \mathrm{H}-2$ & 55.68 & 55.70 & 55.69 & 3.38 & 0.271 & 1.11 & 2.27 \\
\hline $7 \mathrm{H}-5$ & 60.18 & 60.20 & 60.19 & 1.59 & 0.104 & 0.59 & 1.00 \\
\hline $8 \mathrm{H}-2$ & 63.82 & 63.84 & 63.83 & 2.55 & 0.155 & - & - \\
\hline $8 \mathrm{H}-5$ & 68.32 & 68.34 & 68.33 & 3.75 & 0.159 & 2.30 & 1.45 \\
\hline $9 \mathrm{H}-2$ & 74.68 & 74.70 & 74.69 & 2.46 & 0.101 & 1.29 & 1.17 \\
\hline $9 \mathrm{H}-5$ & 79.10 & 79.12 & 79.11 & 2.35 & 0.111 & 1.13 & 1.22 \\
\hline $10 \mathrm{H}-2$ & 84.10 & 84.12 & 84.11 & 2.86 & 0.108 & 1.62 & 1.24 \\
\hline $10 \mathrm{H}-4$ & 87.10 & 87.12 & 87.11 & 2.29 & 0.095 & 1.28 & 1.01 \\
\hline
\end{tabular}


Table T6 (continued).

\begin{tabular}{|c|c|c|c|c|c|c|c|}
\hline \multirow[b]{2}{*}{ Core, section } & \multicolumn{3}{|c|}{ Depth (mbsf) } & \multirow{2}{*}{$\begin{array}{c}\text { TC } \\
\text { (wt\%) }\end{array}$} & \multirow{2}{*}{$\begin{array}{c}\text { TN } \\
\text { (wt\%) }\end{array}$} & \multirow{2}{*}{$\begin{array}{c}\text { TIC } \\
\text { (wt\%) }\end{array}$} & \multirow{2}{*}{$\begin{array}{r}\text { TOC } \\
\text { (wt\% }\end{array}$} \\
\hline & Top & Bottom & Average & & & & \\
\hline $11 \mathrm{H}-3$ & 93.98 & 94.00 & 93.99 & 2.38 & 0.124 & 0.98 & 1.40 \\
\hline $12 \mathrm{H}-3$ & 99.83 & 99.85 & 99.84 & 2.30 & 0.114 & 0.85 & 1.45 \\
\hline $13 \mathrm{H}-4$ & 107.88 & 107.90 & 107.89 & 2.02 & 0.084 & 1.03 & 0.99 \\
\hline $14 \mathrm{H}-3$ & 114.09 & 114.11 & 114.10 & 2.32 & 0.087 & - & - \\
\hline $15 \mathrm{H}-2$ & 118.48 & 118.50 & 118.49 & 2.19 & 0.089 & 1.16 & 1.03 \\
\hline $16 \mathrm{H}-3$ & 124.78 & 124.80 & 124.79 & 2.18 & 0.083 & 1.19 & 0.99 \\
\hline $17 X-3$ & 132.13 & 132.15 & 132.14 & 2.61 & 0.178 & 0.93 & 1.68 \\
\hline $18 X-3$ & 136.33 & 136.35 & 136.34 & 2.11 & 0.106 & 0.81 & 1.30 \\
\hline $19 X-5$ & 148.55 & 148.57 & 148.56 & - & - & 0.42 & - \\
\hline $20 X-5$ & 158.24 & 158.26 & 158.25 & 1.76 & 0.096 & 0.78 & 0.98 \\
\hline $21 X-7$ & 169.64 & 169.66 & 169.65 & 1.96 & 0.116 & 0.71 & 1.25 \\
\hline $22 X-5$ & 178.18 & 178.20 & 178.19 & 1.96 & 0.104 & 0.89 & 1.07 \\
\hline $23 X-6$ & 188.79 & 188.81 & 188.80 & 1.79 & 0.095 & 0.75 & 1.04 \\
\hline $24 X-4$ & 194.91 & 194.93 & 194.92 & 2.46 & 0.193 & 0.95 & 1.51 \\
\hline $25 X-3$ & 202.69 & 202.71 & 202.70 & 1.88 & 0.107 & 0.78 & 1.10 \\
\hline $26 X-4$ & 214.68 & 214.70 & 214.69 & 1.89 & 0.169 & 0.81 & 1.08 \\
\hline $27 X-2$ & 220.00 & 220.02 & 220.01 & 2.24 & 0.104 & 1.25 & 0.99 \\
\hline $28 X-7$ & 236.43 & 236.45 & 236.44 & 2.56 & 0.114 & 1.43 & 1.13 \\
\hline $29 X-3$ & 236.75 & 236.77 & 236.76 & - & - & - & - \\
\hline $29 X-3$ & 236.75 & 236.77 & 236.76 & 2.19 & 0.110 & 1.24 & 0.95 \\
\hline $30 \times-2$ & 240.90 & 240.92 & 240.91 & 1.69 & 0.108 & 0.54 & 1.15 \\
\hline $31 X-4$ & 252.48 & 252.50 & 252.49 & 1.96 & 0.100 & 1.04 & 0.92 \\
\hline $32 X-3$ & 259.83 & 259.85 & 259.84 & 2.34 & 0.119 & 1.22 & 1.12 \\
\hline $32 X-3$ & 259.83 & 259.85 & 259.84 & 2.36 & 0.108 & - & - \\
\hline $33 X-5$ & 271.89 & 271.91 & 271.90 & 1.51 & 0.077 & 0.78 & 0.73 \\
\hline $34 X-2$ & 277.96 & 277.98 & 277.97 & 2.01 & 0.101 & 0.86 & 1.15 \\
\hline $35 X-5$ & 292.08 & 292.10 & 292.09 & 1.54 & 0.118 & 0.37 & 1.17 \\
\hline $36 X-2$ & 297.63 & 297.65 & 297.64 & 1.90 & 0.105 & 0.80 & 1.10 \\
\hline $37 X-2$ & 307.21 & 307.23 & 307.22 & - & - & 1.20 & - \\
\hline $38 \mathrm{X}-1$ & 310.48 & 310.50 & 310.49 & - & - & 1.37 & - \\
\hline $39 X-5$ & 321.68 & 321.70 & 321.69 & - & - & 0.59 & - \\
\hline $40 X-4$ & 329.10 & 329.12 & 329.11 & - & - & 0.75 & - \\
\hline $41 X-5$ & 340.74 & 340.76 & 340.75 & - & - & - & - \\
\hline $42 X-3$ & 347.04 & 347.06 & 347.05 & - & - & 1.15 & - \\
\hline $43 X-5$ & 358.71 & 358.73 & 358.72 & - & - & 0.62 & - \\
\hline $45 X-3$ & 369.65 & 369.67 & 369.66 & - & - & 1.15 & - \\
\hline $46 X-2$ & 374.25 & 374.27 & 374.26 & - & - & 0.69 & - \\
\hline $47 X-2$ & 379.35 & 379.37 & 379.36 & 1.65 & 0.143 & 0.84 & 0.81 \\
\hline $48 \mathrm{X}-1$ & 382.86 & 382.88 & 382.87 & 1.68 & 0.132 & 1.05 & 0.63 \\
\hline $49 X-3$ & 394.36 & 394.38 & 394.37 & 2.23 & 0.153 & 1.51 & 0.72 \\
\hline $50 X-2$ & 402.27 & 402.29 & 402.28 & 1.88 & 0.160 & 1.17 & 0.71 \\
\hline $51 X-5$ & 415.96 & 415.98 & 415.97 & 2.00 & 0.133 & 0.95 & 1.05 \\
\hline $52 X-5$ & 425.00 & 425.02 & 425.01 & - & - & 1.09 & - \\
\hline $53 X-3$ & 430.70 & 430.72 & 430.71 & - & - & 1.13 & - \\
\hline $54 X-5$ & 444.24 & 444.26 & 444.25 & 2.10 & 0.124 & 1.26 & 0.84 \\
\hline $55 X-2$ & 448.81 & 448.83 & 448.82 & - & - & 0.88 & - \\
\hline $56 X-2$ & 458.24 & 458.26 & 458.25 & - & - & - & - \\
\hline $56 X-2$ & 458.24 & 458.26 & 458.25 & 2.14 & 0.241 & 1.33 & 0.81 \\
\hline $57 X-3$ & 469.33 & 469.35 & 469.34 & - & - & 1.48 & - \\
\hline $58 X-2$ & 478.26 & 478.28 & 478.27 & - & - & 0.74 & - \\
\hline $59 X-4$ & 489.66 & 489.68 & 489.67 & - & - & 1.05 & - \\
\hline $60 X-4$ & 499.72 & 499.74 & 499.73 & - & - & 0.58 & - \\
\hline $61 X-4$ & 510.12 & 510.14 & 510.13 & - & - & 0.87 & - \\
\hline $62 X-1$ & 510.24 & 510.26 & 510.25 & - & - & - & - \\
\hline $63 X-4$ & 518.74 & 518.76 & 518.75 & - & - & 0.92 & - \\
\hline
\end{tabular}

$\mathrm{TC}=$ total carbon, $\mathrm{TN}=$ total nitrogen, $\mathrm{TIC}=$ total inorganic carbon, $\mathrm{TOC}=$ total organic carbon. $-=$ not measured. 
Table T7. Summary of APCT-3 temperature measurements, Hole U1378A.

\begin{tabular}{lccccccc}
\hline & $\begin{array}{c}\text { Depth } \\
\text { Core }\end{array}$ & $\begin{array}{c}\text { BWT } \\
\left({ }^{\circ} \mathrm{C}\right)\end{array}$ & $\begin{array}{c}\text { Start fit } \\
(\mathrm{s})\end{array}$ & $\begin{array}{c}\text { End fit } \\
(\mathrm{s})\end{array}$ & $\begin{array}{c}\text { Time } \\
\text { measurement } \\
(\mathrm{min})\end{array}$ & $\begin{array}{c}\text { Equilibrium } \\
\text { temperature } \\
\left({ }^{\circ} \mathrm{C}\right)\end{array}$ & Remark \\
\hline $334-\mathrm{U1378 \textrm {A }}-$ & & & & & & & \\
4H & 33.8 & 11.52 & 4837 & 5427 & 9.8 & 9.94 & Good \\
$7 \mathrm{H}$ & 62.3 & 12.40 & 5048 & 5802 & 12.6 & 11.25 & Good \\
$10 \mathrm{H}$ & 89.6 & 12.77 & 6089 & 6657 & 9.5 & 12.78 & Good \\
$13 \mathrm{H}$ & 109.7 & 12.56 & 6721 & 7362 & 10.74 & 13.80 & Good \\
\hline
\end{tabular}

APCT-3 = advanced piston corer temperature tool, BWT = bottom water temperature. $-=$ not measured. 